\title{
INTRODUCTION TO GENETIC PROGRAMMING
}

\author{
TUTORIAL \\ GECCO-2003 \\ CHICAGO \\ SUNDAY JULY 13, 2003
}

\author{
John R. Koza \\ Consulting Professor (Medical Informatics) \\ Department of Medicine \\ School of Medicine
}

Consulting Professor

Department of Electrical Engineering

School of Engineering

Stanford University

Stanford, California 94305

E-MAIL: koza@stanford.edu

http://www.smi.stanford.edu/people/koza/

http://www.genetic-programming.org

http://www.genetic-programming.com 


\section{THE CHALLENGE}

"How can computers learn to solve problems without being explicitly programmed? In other words, how can computers be made to do what is needed to be done, without being told exactly how to do it?"

— Attributed to Arthur Samuel (1959)

\section{CRITERION FOR SUCCESS}

"The aim [is] ... to get machines to exhibit behavior, which if done by humans, would be assumed to involve the use of intelligence."

— Arthur Samuel (1983) 


\section{SOME (OF THE MANY) \\ REPRESENTATIONS USED TO TRY TO \\ ACHIEVE MACHINE INTELLIGENCE IN \\ THE FIELDS OF ARTIFICIAL \\ INTELLIGENCE (AI) AND MACHINE \\ LEARNING (ML)}

- Decision trees

- If-then production rules (e.g., expert system)

- Horn clauses

- Neural nets (matrices of numerical weights)

- Bayesian networks

- Frames

- Propositional logic

- Binary decision diagrams

- Formal grammars

- Vectors of numerical coefficients for polynomials (adaptive systems)

- Tables of values (reinforcement learning)

- Conceptual clusters

- Concept sets

- Parallel if-then rules (e.g., genetic classifier systems) 


\section{A COMPUTER PROGRAM}

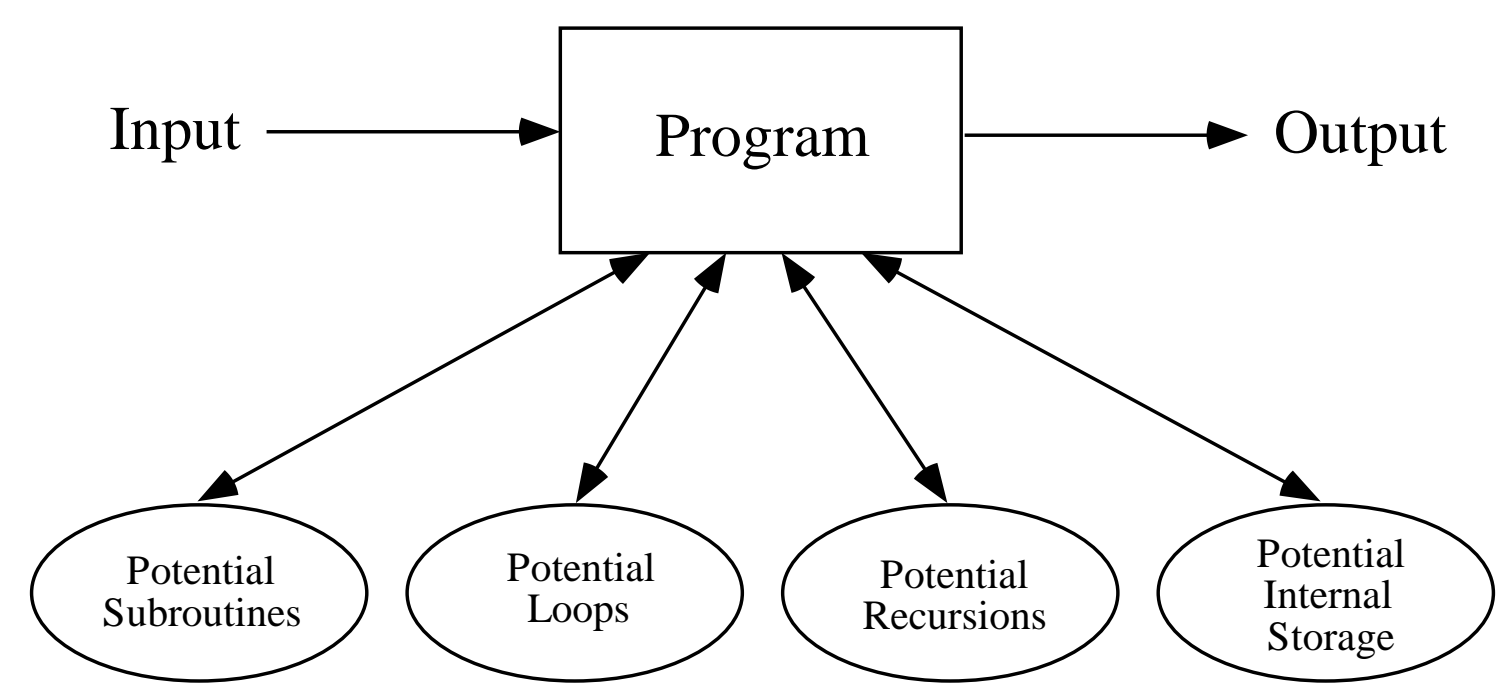

REPRESENTATION

- "Our view is that computer programs are the best representation of computer programs." 


\section{FLOWCHART FOR GENETIC PROGRAMMING (GP)}

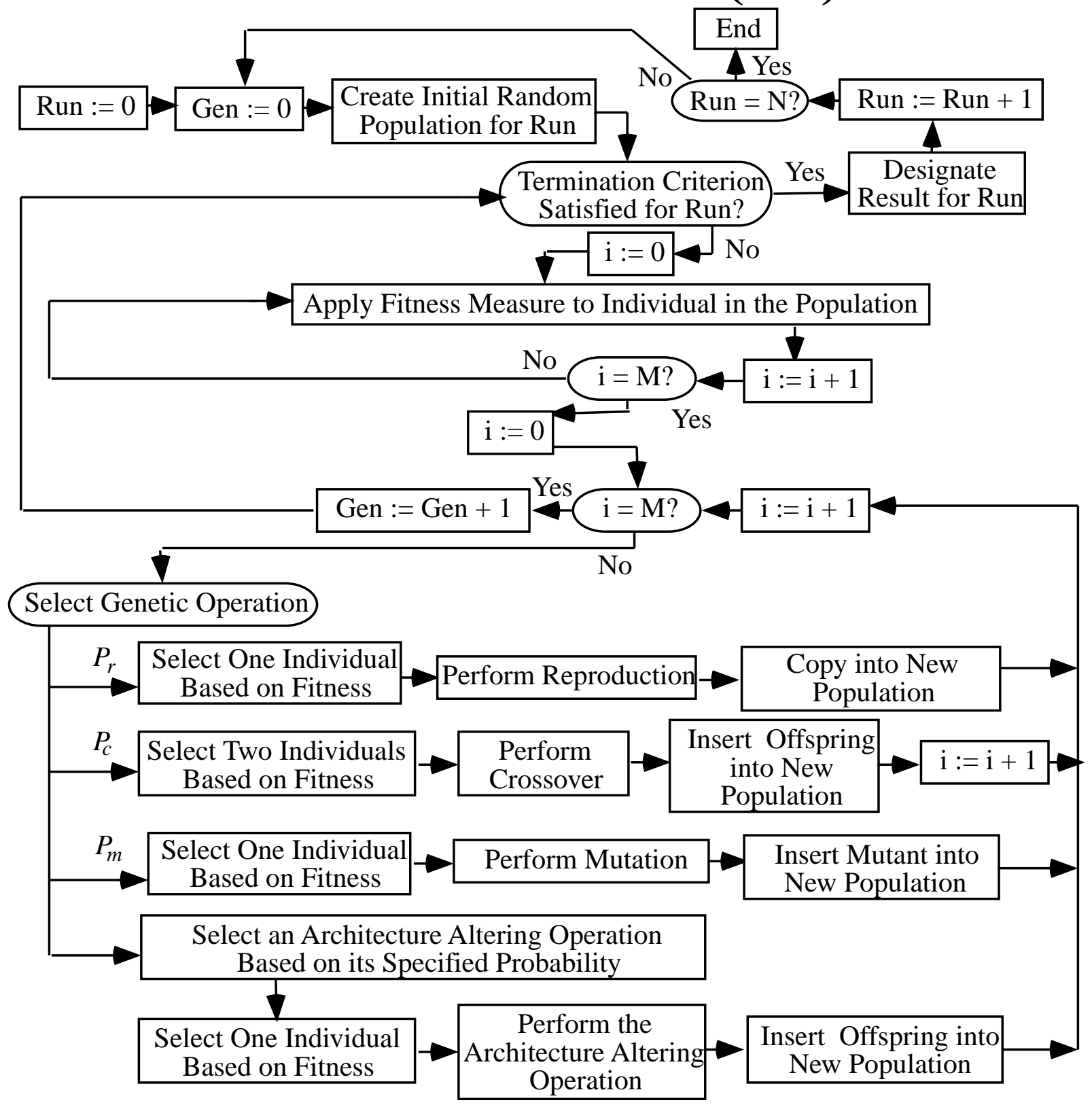




\section{COMPUTER PROGRAM \\ $=$ PARSE TREE $=$ PROGRAM TREE \\ $=$ PROGRAM IN LISP $=$ DATA $=$ LIST \\ $(+12$ (IF (> TIME 10) 3 4))}

- ATOMS (TERMINALS) $=1 ， 2 ， 10 ３ ， 4$, TIME

- FUNCTIONS = +, IF , >

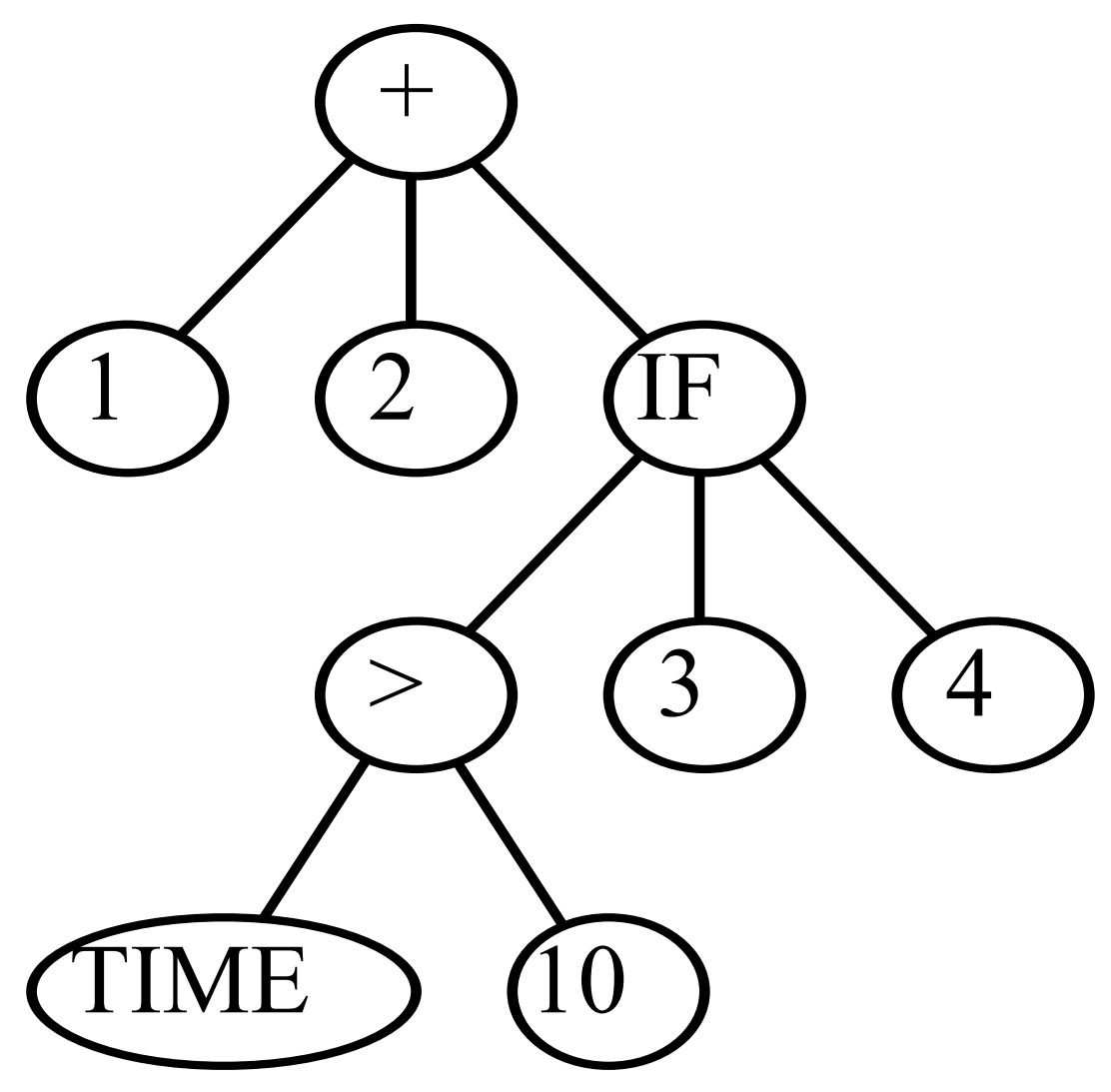




\section{EXAMPLE OF RANDOM CREATION OF A PROGRAM TREE}

- Terminal set $T=\{A, B, C\}$

- Function set $\mathrm{F}=\left\{+,-, *, \frac{\circ}{\circ}\right.$, IFLTE $\}$

\section{BEGIN WITH TWO-ARGUMENT +}

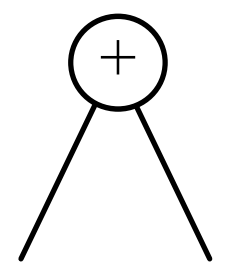

CONTINUE WITH TWO-ARGUMENT *

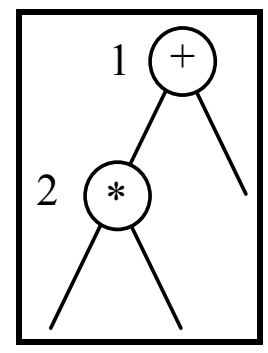

COMPLETE WITH TERMINALS A, B,

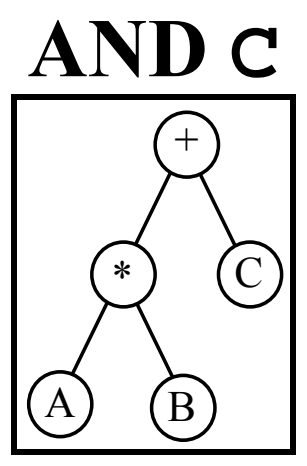

- The result is a syntactically valid executable program (provided the set of functions is closed) 


\section{MUTATION OPERATION}

- Select parent probabilistically based on fitness

- Pick point from 1 to NUMBER-OF-POINTS

- Delete subtree at the picked point

- Grow new subtree at the mutation point in same way as generated trees for initial random population (generation 0 )

- The result is a syntactically valid executable program
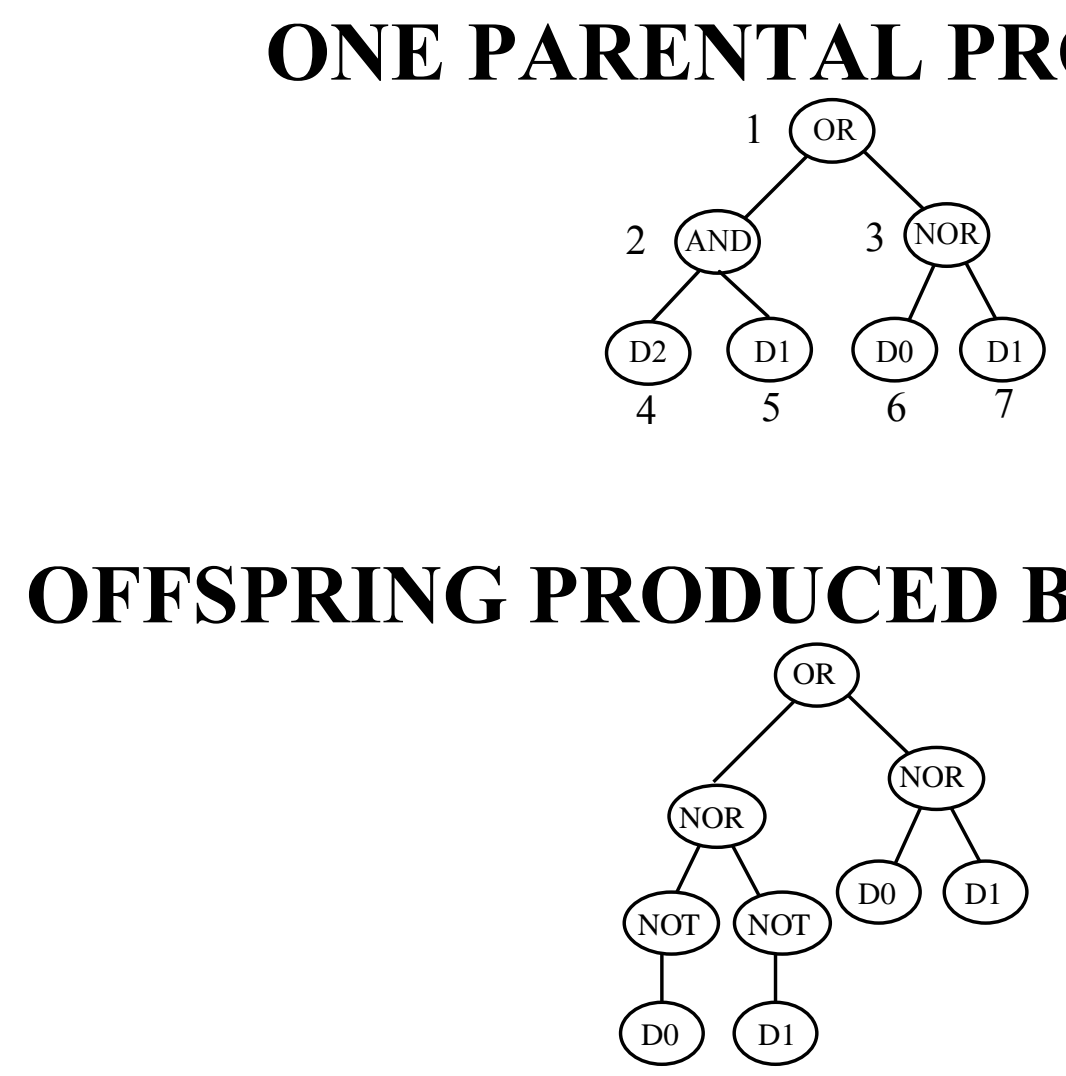


\section{CROSSOVER (SEXUAL \\ RECOMBINATION) OPERATION FOR COMPUTER PROGRAMS}

- Select two parents probabilistically based on fitness

- Randomly pick a number from 1 to NUMBER-OF-POINTS

- independently for each of the two parental programs

- Identify the two subtrees rooted at the two picked points

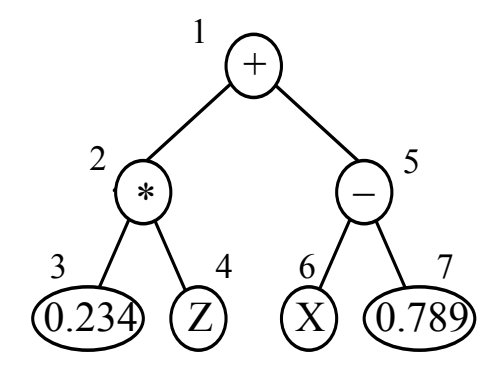

$0.234 Z+X-0.789$

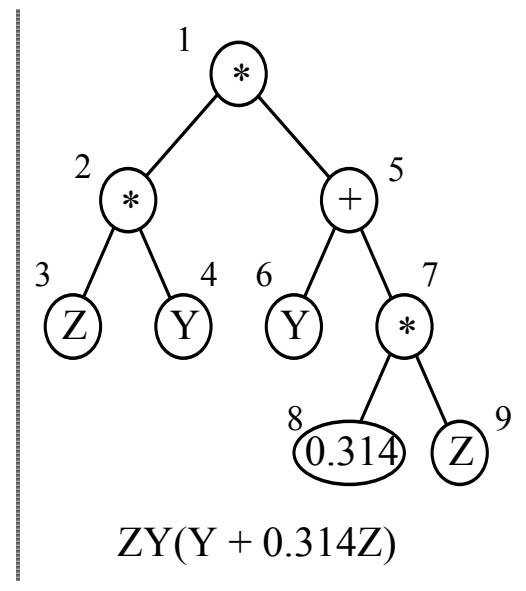

Parent 1:

$(+(* 0.234 \mathrm{Z})(-\mathrm{X} 0.789))$

Parent 2:

$(*(* Z Y)(+Y(* 0.314 Z)))$ 


\section{THE CROSSOVER OPERATION (TWO OFFSPRING VERSION)}

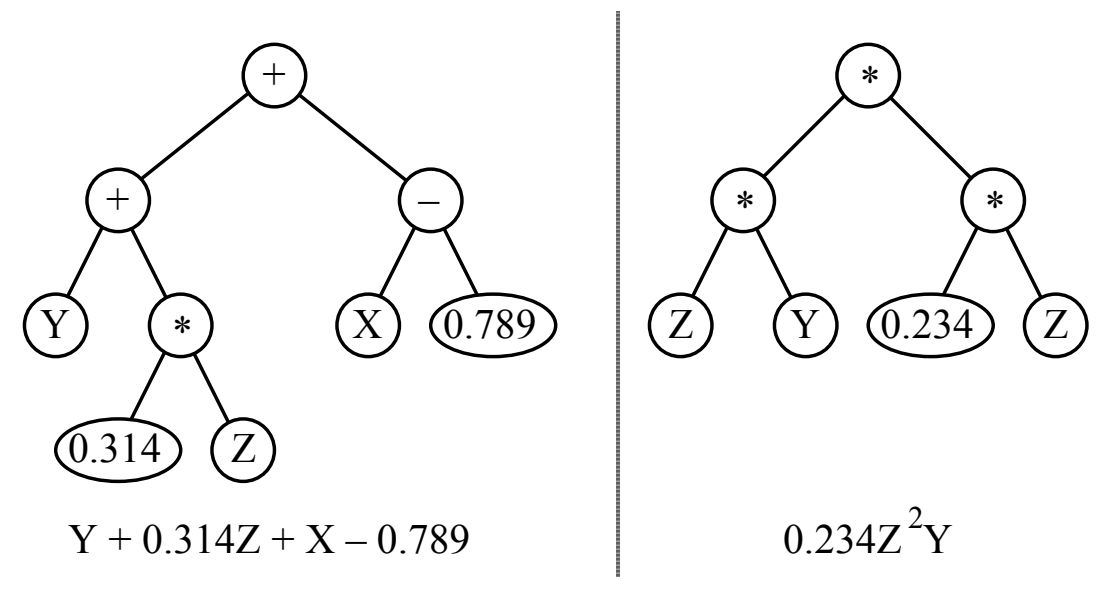

\section{Offspring 1:}

$$
\left(+\frac{(+Y(* 0.314 Z))}{(-X 0.789))}\right.
$$

Offspring 2:

$(*(* Z Y)(* 0.234 \mathrm{Z}))$

- The result is a syntactically valid executable program 


\section{FIVE MAJOR PREPARATORY STEPS FOR GP}

- Determining the set of terminals

- Determining the set of functions

- Determining the fitness measure

- Determining the parameters for the run

- population size

- number of generations

- minor parameters

- Determining the method for designating a result and the criterion for terminating a run

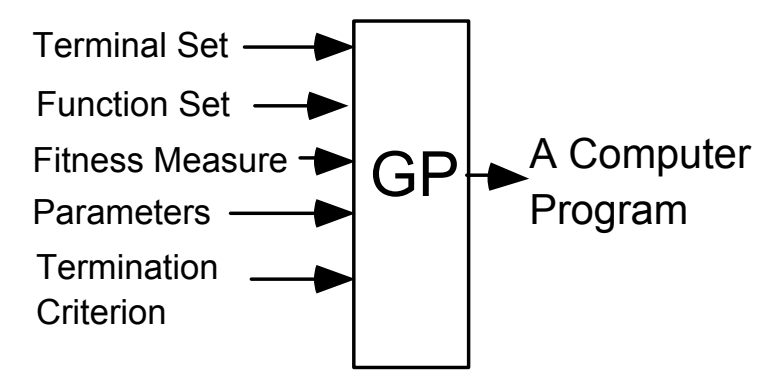




\begin{tabular}{|c|c|c|}
\hline & Objective: & $\begin{array}{l}\text { Find a computer program with one } \\
\text { input (independent variable } x \text { ), } \\
\text { whose output equals the value of the } \\
\text { quadratic polynomial } x^{2}+x+1 \text { in } \\
\text { range from }-1 \text { to }+1 \text {. }\end{array}$ \\
\hline 1 & Terminal set: & $\mathbf{T}=\{\mathbf{X}\}$ \\
\hline 2 & Function set: & $\begin{array}{l}\mathrm{F}=\left\{+,-, \quad \star, \frac{\circ}{\circ}\right\} \\
\text { NOTE: The protected division } \\
\text { function } \% \text { returns a value of } 1 \text { when } \\
\text { division by } 0 \text { is attempted (including } \\
0 \text { divided by } 0 \text { ) }\end{array}$ \\
\hline 3 & Fitness: & $\begin{array}{l}\text { The sum of the absolute value of the } \\
\text { differences (errors), computed (in } \\
\text { some way) over values of the } \\
\text { independent variable } x \text { from }-1.0 \text { to } \\
+1.0 \text {, between the program's output } \\
\text { and the target quadratic polynomial } \\
x^{2}+x+1 \text {. }\end{array}$ \\
\hline 4 & Parameters: & Population size $M=4$ \\
\hline 5 & Termination: & $\begin{array}{l}\text { An individual emerges whose sum } \\
\text { of absolute errors is less than } 0.1\end{array}$ \\
\hline
\end{tabular}




\section{SYMBOLIC REGRESSION OF QUADRATIC POLYNOMIAL $X^{2}+X+1$}

\section{INITIAL POPULATION OF FOUR RANDOMLY CREATED INDIVIDUALS OF GENERATION 0}
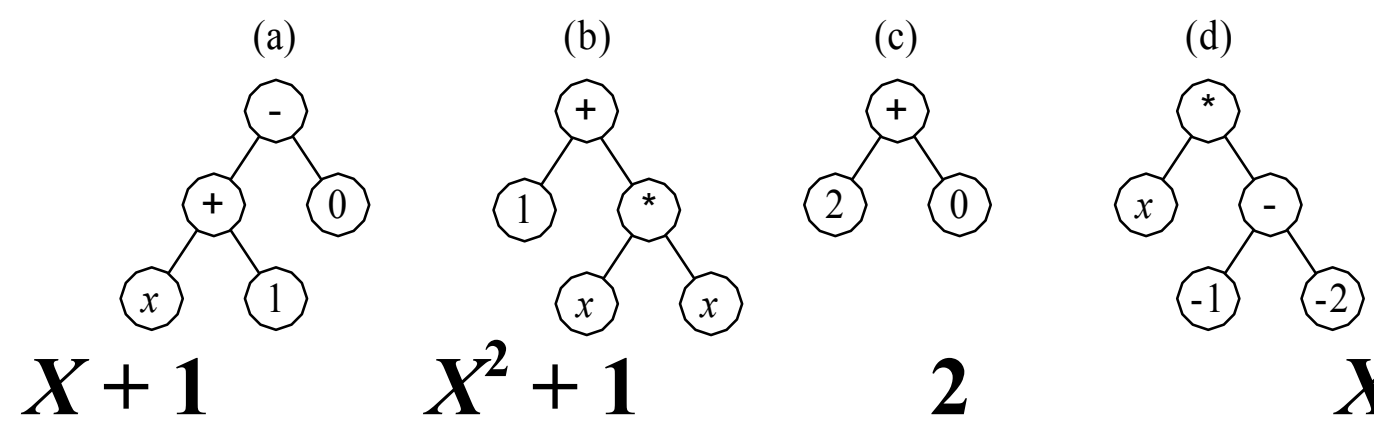

\section{FITNESS}
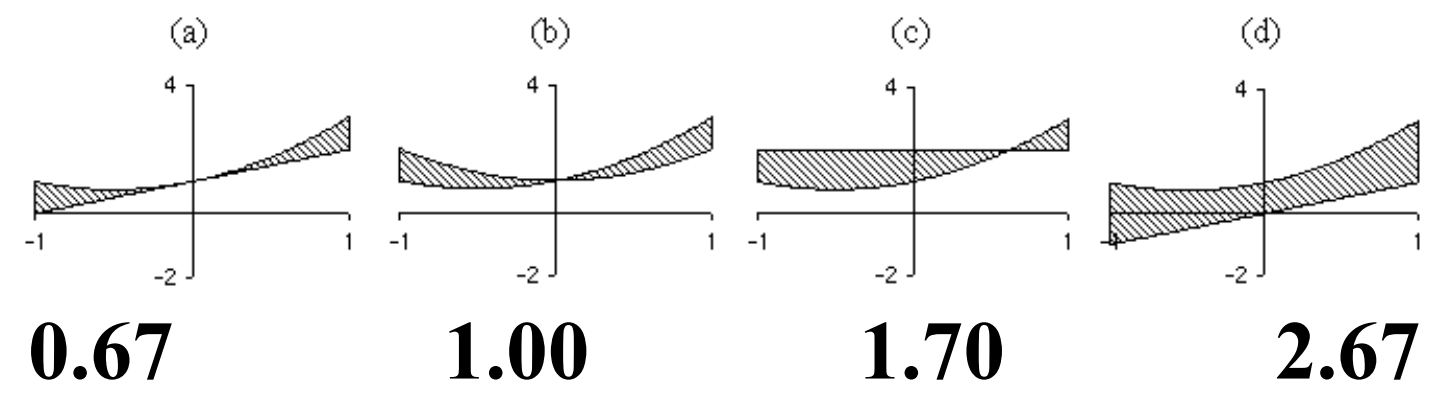


\section{SYMBOLIC REGRESSION OF QUADRATIC POLYNOMIAL $X^{2}+X+1$}
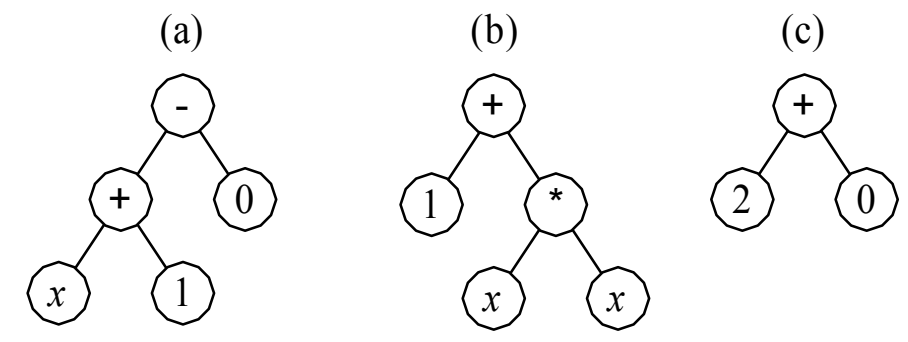

(d)

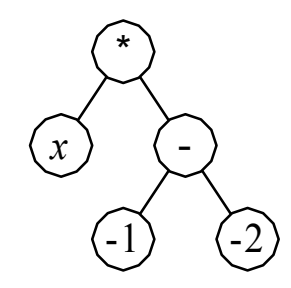

\section{GENERATION 1}
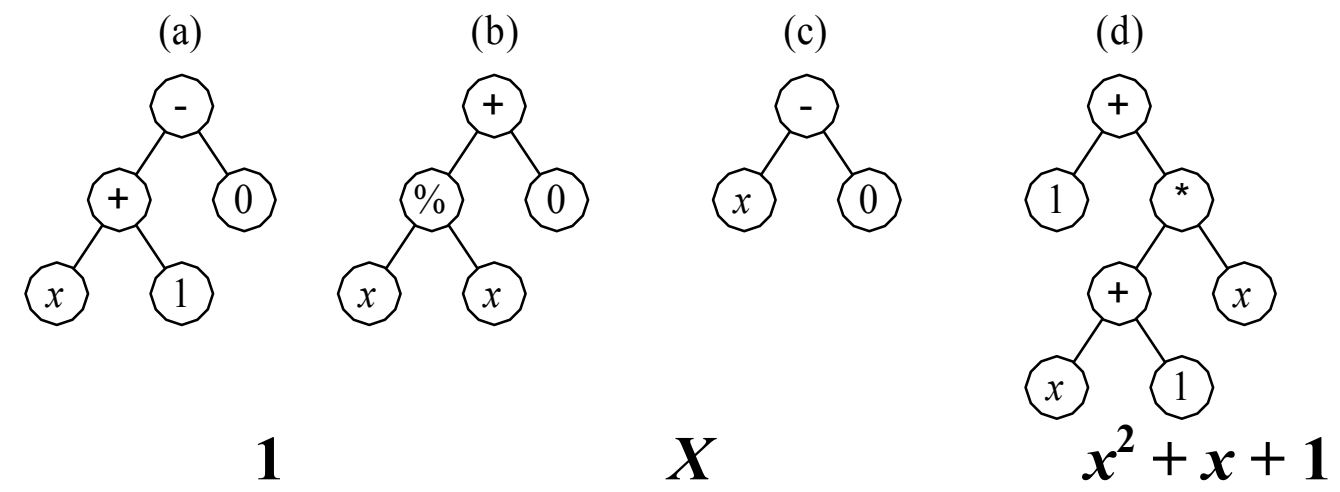

$x+1$

1

$X$

$$
x^{2}+x+1
$$

Copy of (a) Mutant of (c) $\quad$ First $\quad$ Second

offspring of offspring of —picking " 2 " crossover of crossover of as mutation (a) and (b) (a) and (b) point

—picking "+" —picking "+" of parent (a) of parent (a) and left-most and left-most " $x$ " of parent " $x$ " of parent (b) as (b) as crossover crossover points points 
SYMBOLIC REGRESSION

OF QUARTIC POLYNOMIAL $X^{4}+X^{3}+X^{2}+X$
(WITH 21 FITNESS CASES)

\begin{tabular}{|c|c|c|}
\hline $\begin{array}{l}\text { Independent } \\
\text { variable } \\
\text { (Input) }\end{array}$ & $\boldsymbol{X}$ & $\begin{array}{l}\text { Dependent } \\
\text { Variable } \\
\text { (Output) }\end{array}$ \\
\hline-1.0 & & $\mathbf{0 . 0 0 0 0}$ \\
\hline-0.9 & & -0.1629 \\
\hline-0.8 & & -0.2624 \\
\hline-0.7 & & -0.3129 \\
\hline-0.6 & & -0.3264 \\
\hline-0.5 & & -0.3125 \\
\hline-0.4 & & -0.2784 \\
\hline-0.3 & & -0.2289 \\
\hline-0.2 & & -0.1664 \\
\hline-0.1 & & -0.0909 \\
\hline 0 & & 0.0 \\
\hline 0.1 & & 0.1111 \\
\hline 0.2 & & 0.2496 \\
\hline 0.3 & & 0.4251 \\
\hline 0.4 & & 0.6496 \\
\hline 0.5 & & 0.9375 \\
\hline 0.6 & & 1.3056 \\
\hline 0.7 & & 1.7731 \\
\hline 0.8 & & 2.3616 \\
\hline 0.9 & & 3.0951 \\
\hline 1.0 & & 4.0000 \\
\hline
\end{tabular}




\section{TABLEAU - SYMBOLIC REGRESSION OF QUARTIC POLYNOMIAL $\boldsymbol{X}^{4}+\boldsymbol{X}^{3}+\boldsymbol{X}^{2}+\boldsymbol{X}$} \begin{tabular}{l|l} 
Objective: & Find a function of one independent
\end{tabular} variable, in symbolic form, that fits a given sample of $21\left(x_{i}, y_{i}\right)$ data points

\begin{tabular}{|l|l|}
\hline Terminal set: & $\mathrm{x}$ (the independent variable). \\
\hline Function set: & $\begin{array}{l}+,{ }^{\prime}-{ }^{*} \\
\text { RLOG }\end{array}$
\end{tabular}

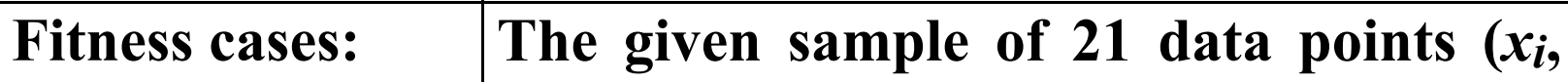
$\left.y_{i}\right)$ where the $x_{i}$ are in interval $[-1,+1]$.

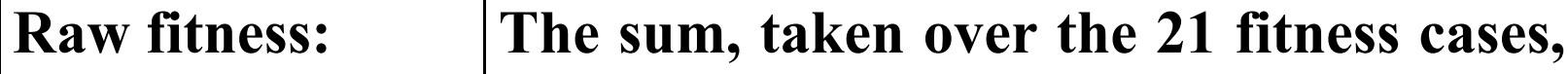
of the absolute value of difference between value of the dependent variable produced by the individual program and the target value $y_{i}$ of the dependent variable.

Standardized $\quad$ Equals raw fitness.

fitness:

Hits:

Number of fitness cases $(0-21)$ for which the value of the dependent variable produced by the individual program comes within 0.01 of the target value $y_{i}$ of the dependent variable.

\begin{tabular}{|l|l|}
\hline Wrapper: & None. \\
\hline Parameters: & $\begin{array}{l}\text { Population size, } M=500 . \\
\text { Maximum number of generations to } \\
\text { run, } G=51 .\end{array}$ \\
\hline $\begin{array}{l}\text { Success } \\
\text { Predicate: }\end{array}$ & An individual program scores 21 hits. \\
\hline
\end{tabular}




\section{SYMBOLIC REGRESSION \\ OF QUARTIC POLYNOMIAL $\boldsymbol{X}^{4}+\boldsymbol{X}^{3}+\boldsymbol{X}^{2}+\boldsymbol{X}$}

WORST-OF-GENERATION INDIVIDUAL

IN GENERATION 0 WITH RAW FITNESS

OF 1038

$\left(\operatorname{EXP}\left(-\left(\begin{array}{llll}\circ & X & (-X & (\operatorname{SIN} X)))\end{array}\right.\right.\right.$

$($ RLOG (RLOG $(* X X))))$ )

Equivalent to

$$
e x /(x-\sin x)-\log \log x^{*} x
$$




\section{SYMBOLIC REGRESSION}

OF QUARTIC POLYNOMIAL $\boldsymbol{X}^{4}+\boldsymbol{X}^{3}+\boldsymbol{X}^{2}+\boldsymbol{X}$

\section{MEDIAN INDIVIDUAL IN GENERATION 0 WITH RAW FITNESS OF 23.67 (AVERGAGE ERROR OF 1.3)}

$(\cos (\cos (+(-(* x) x) \quad(\% x$ X) ) $\mathrm{X}$ )) )

Equivalent to

$\operatorname{Cos}\left[\operatorname{Cos}\left(x^{2}+x-1\right)\right]$

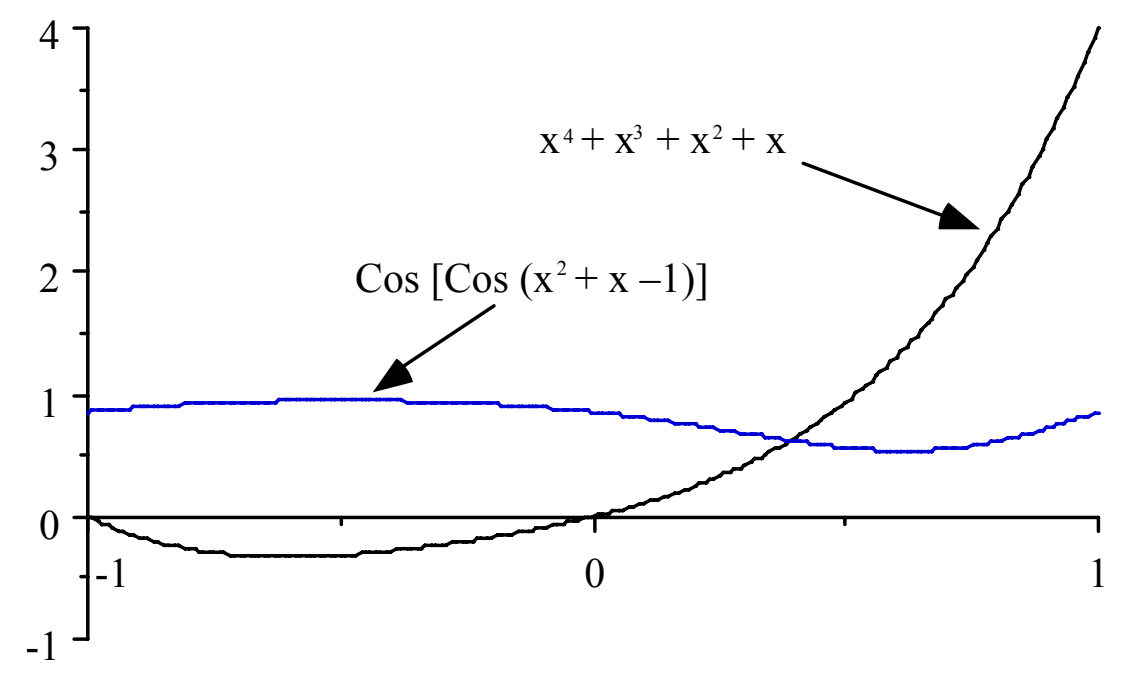




\section{SYMBOLIC REGRESSION}

OF QUARTIC POLYNOMIAL $X^{4}+X^{3}+X^{2}+X$

BEST-OF-GENERATION INDIVIDUAL IN GENERATION 0 WITH RAW FITNESS OF 4.47 (AVERGAGE ERROR OF 0.2)

$\left(* \mathrm{X}\left(+\left(+\left(-\left(\begin{array}{llllll}\circ & \mathrm{X} & \mathrm{X}\end{array}\right)\left(\begin{array}{lll}\% & \mathrm{X} & \mathrm{X}\end{array}\right)\right)\right.\right.\right.$

$(\operatorname{SIN}(-X X)))$ (RLOG (EXP (EXP X)) )) (

Equivalent to

xex

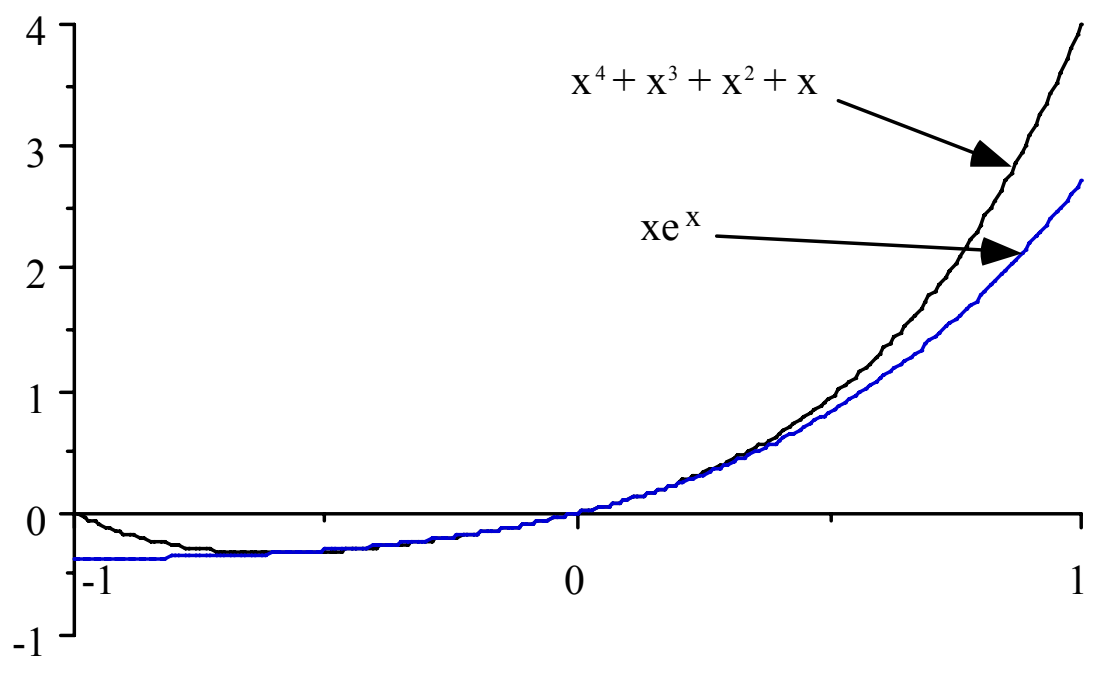




\section{SYMBOLIC REGRESSION \\ OF QUARTIC POLYNOMIAL $\boldsymbol{X}^{4}+\boldsymbol{X}^{3}+\boldsymbol{X}^{2}+\boldsymbol{X}$ \\ CREATION OF GENERATION 1 FROM \\ GENERATION 0}

- In the so-called "generational" model for genetic algorithms, a new population is created that is equal in size to the old population

- 1\% mutation (i.e., 5 individuals out of 500)

- 9\% reproduction (i.e., 45 individuals)

- $90 \%$ crossover (i.e., 225 pairs of parents - yielding 450 offspring)

- All participants in mutation, reproduction, and crossover are chosen from the current population PROBABILISTICALLY, BASED ON FITNESS

- Anything can happen

- Nothing is guaranteed

- The search is heavily (but not completely) biased toward high-fitness individuals

- The best is not guaranteed to be chosen

- The worst is not necessarily excluded

- Some (but not much) attention is given even to lowfitness individuals 


\section{SYMBOLIC REGRESSION}

OF QUARTIC POLYNOMIAL $\boldsymbol{X}^{4}+\boldsymbol{X}^{3}+\boldsymbol{X}^{2}+\boldsymbol{X}$

BEST-OF-GENERATION INDIVIDUAL IN GENERATION 2 WITH RAW FITNESS OF 2.57 (AVERGAGE ERROR OF 0.1)

$(+\quad(*)(+x)(* x)(* x) \quad(\% \quad(\% x$ X) $(+x$ X) )) ))

$(+X(* x X))) X) X)$

Equivalent to...

$$
x^{4}+1.5 x^{3}+0.5 x^{2}+x
$$




\section{SYMBOLIC REGRESSION}

OF QUARTIC POLYNOMIAL $\boldsymbol{X}^{4}+\boldsymbol{X}^{3}+\boldsymbol{X}^{2}+\boldsymbol{X}$

$$
\begin{aligned}
& \text { BEST-OF-RUN INDIVIDUAL IN } \\
& \text { GENERATION 34 WITH RAW FITNESS } \\
& \text { OF 0.00 (100\%-CORRECT) } \\
& (+\mathrm{x}(*(+\mathrm{x}(*(*)(+\mathrm{x}(-)(\cos \\
& (-\mathrm{x} x))\left(\begin{array}{llll}
(-\mathrm{x} x))) & \mathrm{x}) & \mathrm{x})) & \mathrm{x}))
\end{array}\right.
\end{aligned}
$$

Equivalent to

$$
x^{4}+x^{3}+x^{2}+x
$$

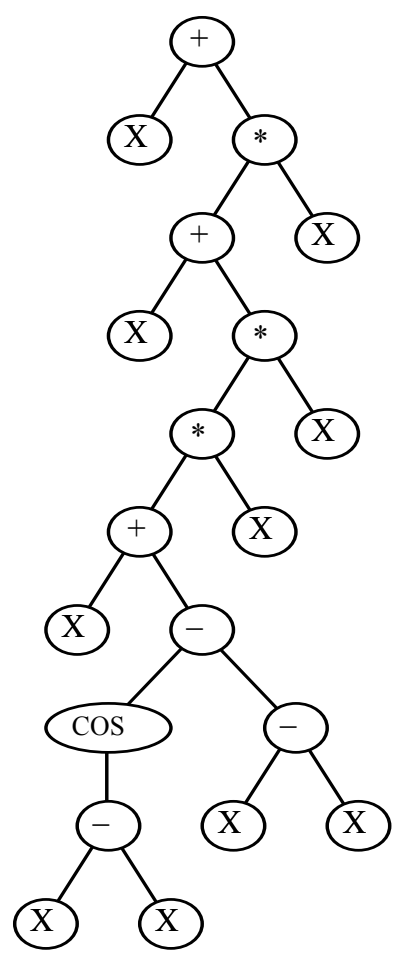




\section{SYMBOLIC REGRESSION \\ OF QUARTIC POLYNOMIAL $\boldsymbol{X}^{4}+\boldsymbol{X}^{3}+\boldsymbol{X}^{2}+\boldsymbol{X}$}

\section{OBSERVATIONS}

- GP works on this problem

- GP determines the size and shape of the solution

- number of operations needed to solve the problem

- size and shape of the program tree

- content of the program tree (i.e., sequence of operations)

- GP operates the same whether the solution is linear, polynomial, a rational fraction of polynomials, exponential, trigonometric, etc.

- It's not how a human programmer would have done it

- $\operatorname{Cos}(X-X)=1$

- Not parsimonious

- The extraneous functions - SIN, EXP, RLOG, and RCOS are absent in the best individual of later generations because they are detrimental

- $\operatorname{Cos}(X-X)=1$ is the exception that proves the rule

- The answer is algebraically correct (hence no further cross validation is needed) 


\section{CLASSIFICATION PROBLEM INTER-TWINED SPIRALS}

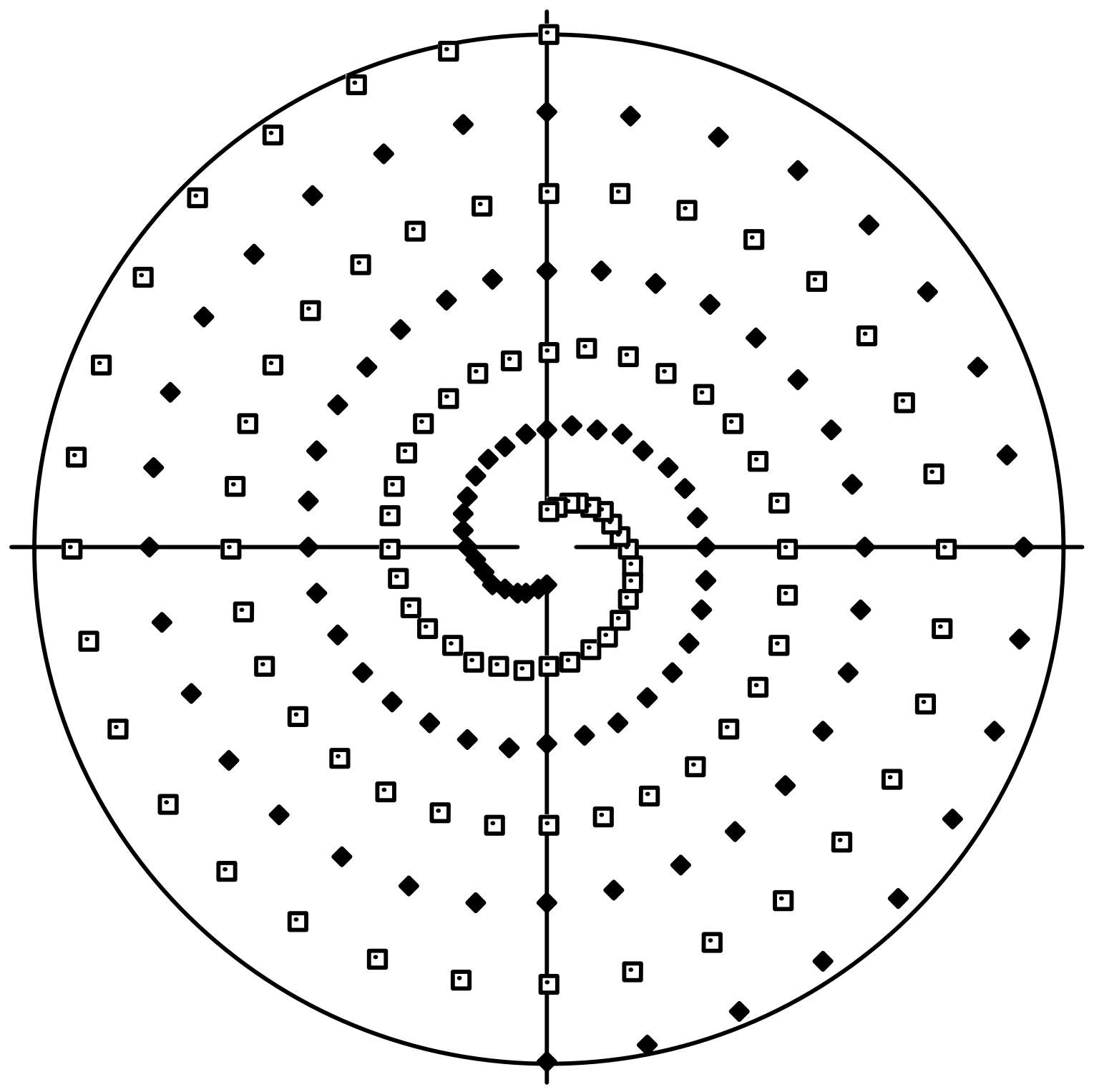




\begin{tabular}{|c|c|}
\hline Objective: & $\begin{array}{l}\text { Find a program to classify a given point } \\
\text { in the } x-y \text { plane to the red or blue spiral. }\end{array}$ \\
\hline Terminal set: & $\begin{array}{l}\mathrm{X}, \mathrm{Y}, \mathfrak{R}, \text { where } \mathfrak{R} \text { is the ephemeral } \\
\text { random floating-point constant ranging } \\
\text { between }-1.000 \text { and }+1.000 \text {. }\end{array}$ \\
\hline Function set: &,,$+- *$, $\frac{\circ}{\partial}$ IFLTE, SIN, COS. \\
\hline Fitness cases: & 194 points in the $x-y$ plane. \\
\hline Raw fitness: & $\begin{array}{l}\text { The number of correctly classified points } \\
(0-194)\end{array}$ \\
\hline $\begin{array}{l}\text { Standardized } \\
\text { fitness: }\end{array}$ & $\begin{array}{l}\text { The maximum raw fitness (i.e., 194) } \\
\text { minus the raw fitness. }\end{array}$ \\
\hline Hits: & Equals raw fitness. \\
\hline Wrapper: & $\begin{array}{l}\text { Maps any individual program returning } \\
\text { a positive value to class }+1 \text { (red) and } \\
\text { maps all other values to class }-1 \text { (blue). }\end{array}$ \\
\hline Parameters: & $M=10,000$ (with over-selection). $G=51$. \\
\hline $\begin{array}{l}\text { Success } \\
\text { predicate: }\end{array}$ & An individual program scores 194 hits. \\
\hline
\end{tabular}




\section{WALL-FOLLOWING PROBLEM}

\section{SONAR SENSORS}

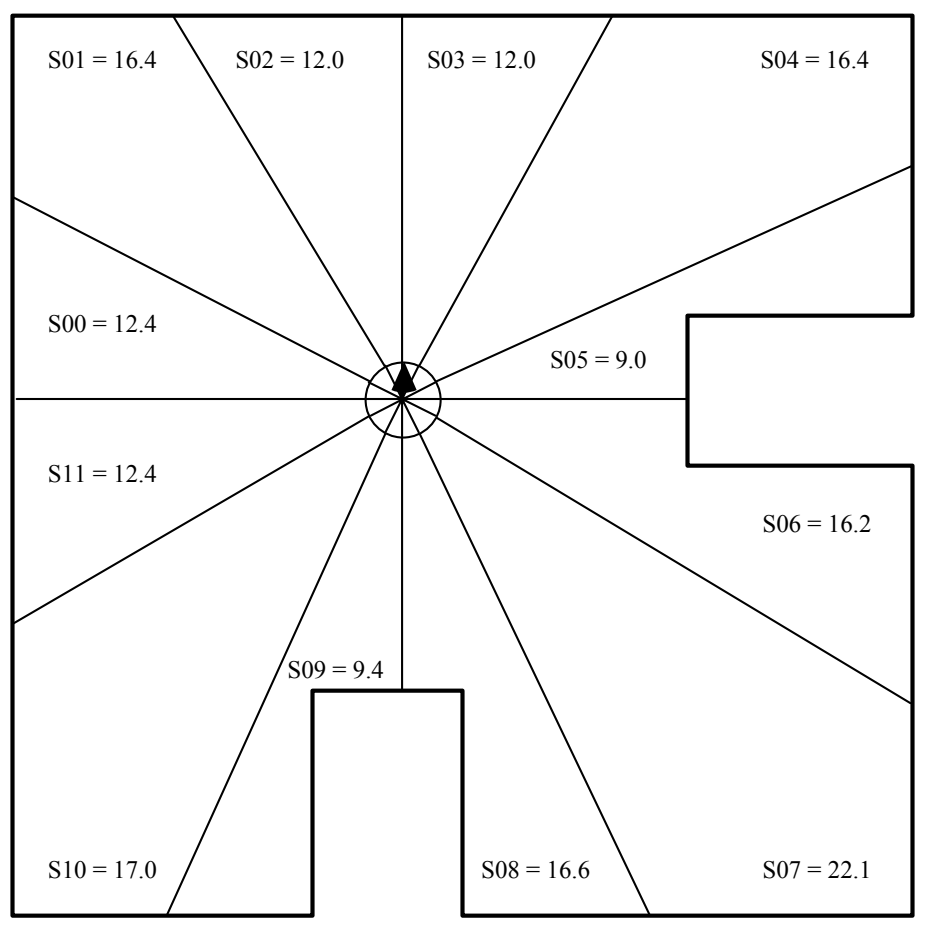




\section{WALL-FOLLOWING PROBLEM FITNESS MEASURE}

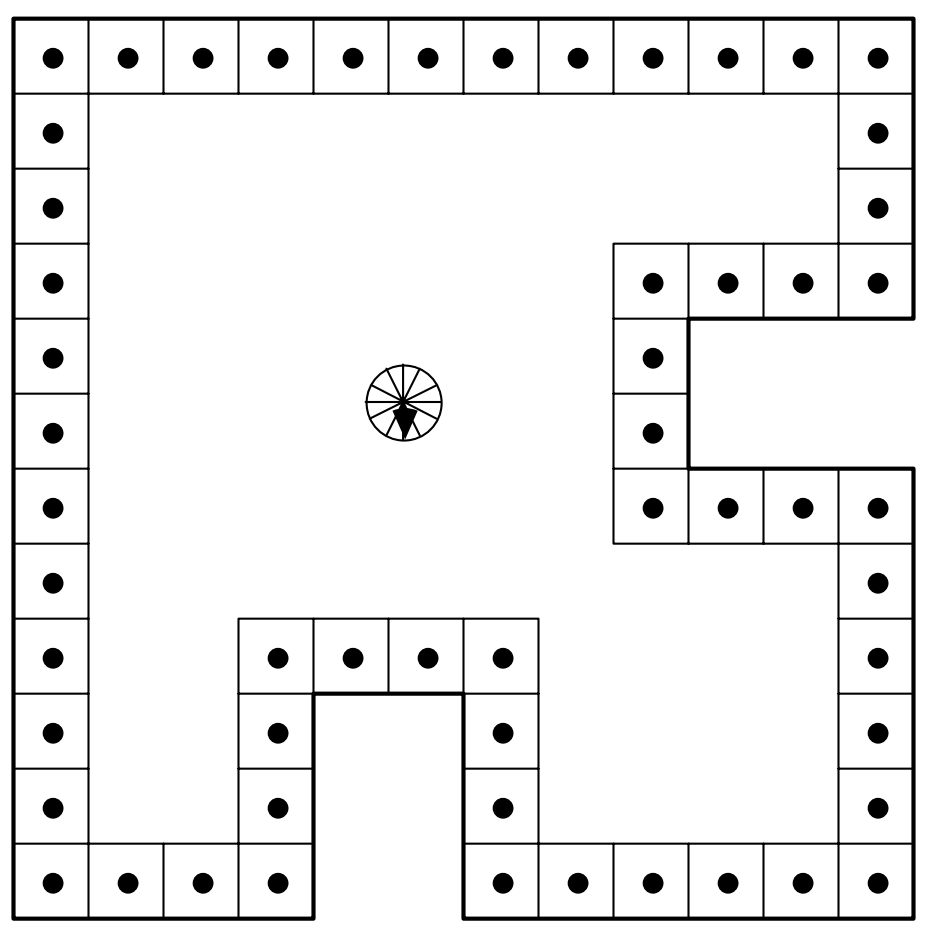




\section{WALL-FOLLOWING PROBLEM BEST PROGRAM OF GENERATION 57}

- Scores 56 hits (out of 56)

- 145point program tree

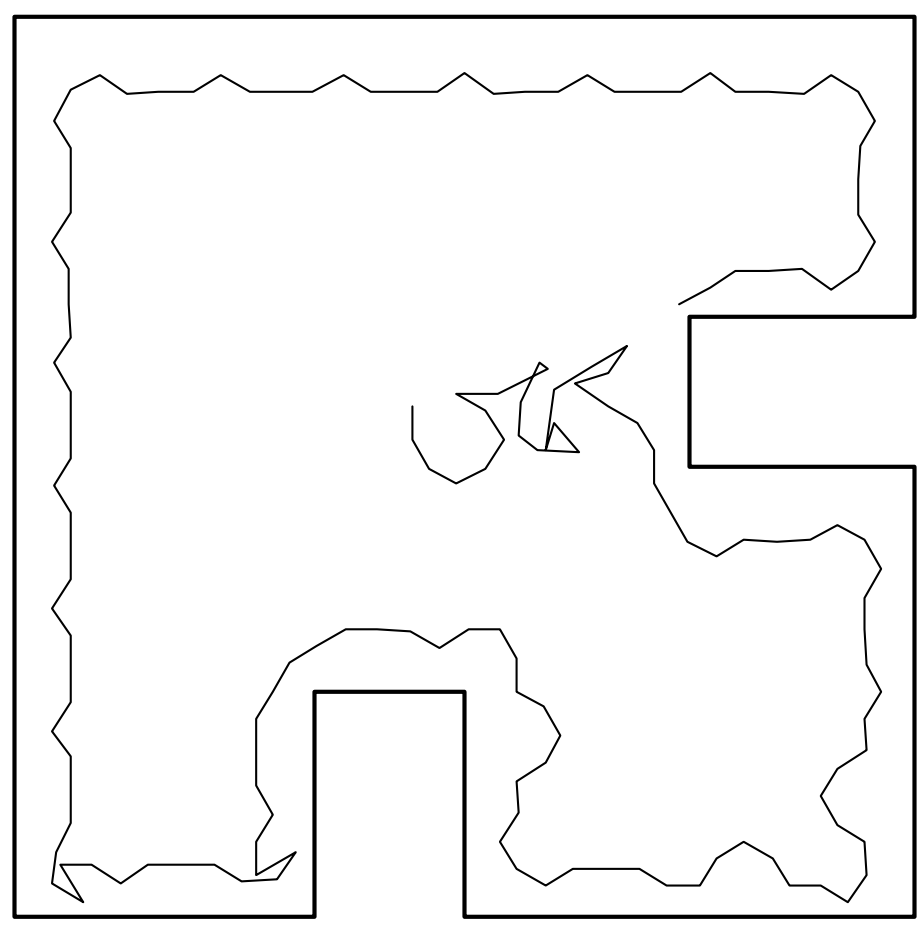




\section{PROBLEMS SHOWN IN 1992 VIDEOTAPE \\ GENETIC PROGRAMMING: THE MOVIE \\ (KOZA AND RICE 1992)}

- Symbolic Regression

- Intertwined Spirals

- Artificial Ant

- Truck Backer Upper

- Broom Balancing

- Wall Following

- Box Moving

- Discrete Pursuer-Evader Game

- Differential Pursuer-Evader Game

- Co-Evolution of Game-Playing Strategies

- Inverse Kinematics

- Emergent Collecting

- Central Place Foraging

- Block Stacking

- Randomizer

- 1-D Cellular Automata

- 2-D Cellular Automata

- Task Prioritization

- Programmatic Image Compression

- Finding $3 \sqrt{ } 2$

- Econometric Exchange Equation

- Optimization (Lizard)

- Boolean 11-Multiplexer

- 11-Parity-Automatically Defined Functions 


\section{AUTOMATICALLY DEFINED FUNCTIONS (ADFs, SUBROUTINES)}

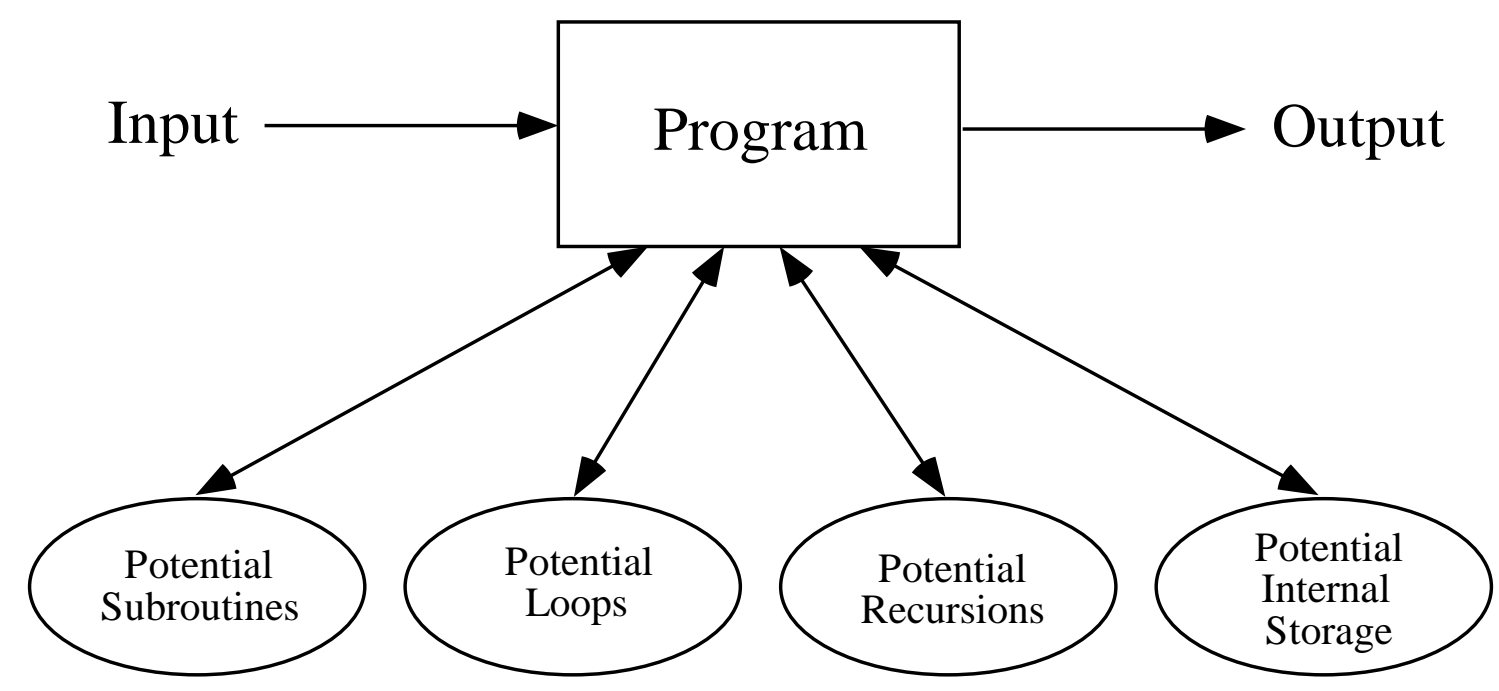

- Subroutines provide one way to REUSE code - possibly with different instantiations of the dummy variables (formal parameters)

- Loops (and iterations) provide a $2^{\text {nd }}$ way to REUSE code - Recursion provide a $3^{\text {rd }}$ way to REUSE code

- Memory provides a $4^{\text {th }}$ way - to REUSE the results of executing code 


\section{AUTOMATICALLY DEFINED FUNCTIONS (ADFs, SUBROUTINES)}

10 FITNESS-CASES SHOWING THE VALUE OF THE DEPENDENT VARIABLE, $D$, ASSOCIATED WITH THE VALUES OF THE SIX INDEPENDENT VARIABLES, $L_{0}, W_{0}, H_{0}, L_{1}, W_{1}, H_{1}$

\begin{tabular}{|l|l|l|l|l|l|l|r|}
\hline $\begin{array}{l}\text { Fitness } \\
\text { case }\end{array}$ & $L_{0}$ & $W_{0}$ & $H_{0}$ & $L_{1}$ & $W_{1}$ & $H_{1}$ & $\begin{array}{r}\text { Dependent } \\
\text { variable } \boldsymbol{D}\end{array}$ \\
\hline $\mathbf{1}$ & 3 & 4 & 7 & 2 & 5 & 3 & $\mathbf{5 4}$ \\
\hline $\mathbf{2}$ & 7 & 10 & 9 & 10 & 3 & 1 & $\mathbf{6 0 0}$ \\
\hline $\mathbf{3}$ & 10 & 9 & 4 & 8 & 1 & 6 & $\mathbf{3 1 2}$ \\
\hline $\mathbf{4}$ & 3 & 9 & 5 & 1 & 6 & 4 & $\mathbf{1 1 1}$ \\
\hline $\mathbf{5}$ & 4 & 3 & 2 & 7 & 6 & 1 & $\mathbf{- 1 8}$ \\
\hline $\mathbf{6}$ & 3 & 3 & 1 & 9 & 5 & 4 & $\mathbf{- 1 7 1}$ \\
\hline $\mathbf{7}$ & 5 & 9 & 9 & 1 & 7 & 6 & $\mathbf{3 6 3}$ \\
\hline $\mathbf{8}$ & 1 & 2 & 9 & 3 & 9 & 2 & $\mathbf{- 3 6}$ \\
\hline $\mathbf{9}$ & 2 & 6 & 8 & 2 & 6 & 10 & $\mathbf{- 2 4}$ \\
\hline $\mathbf{1 0}$ & 8 & 1 & 10 & 7 & 5 & 1 & $\mathbf{4 5}$ \\
\hline
\end{tabular}




\section{AUTOMATICALLY DEFINED \\ FUNCTIONS (ADFs, SUBROUTINES)}

\section{SOLUTION WITHOUT ADFs}

$\left(\begin{array}{lllll}(* & (* \text { WO } & \text { LO }) & \text { HO }\end{array}\right)$
$(*$ (* W1 L1)

$D=W 0 * L 0 * H 0-W 1 * L 1 * H 1$
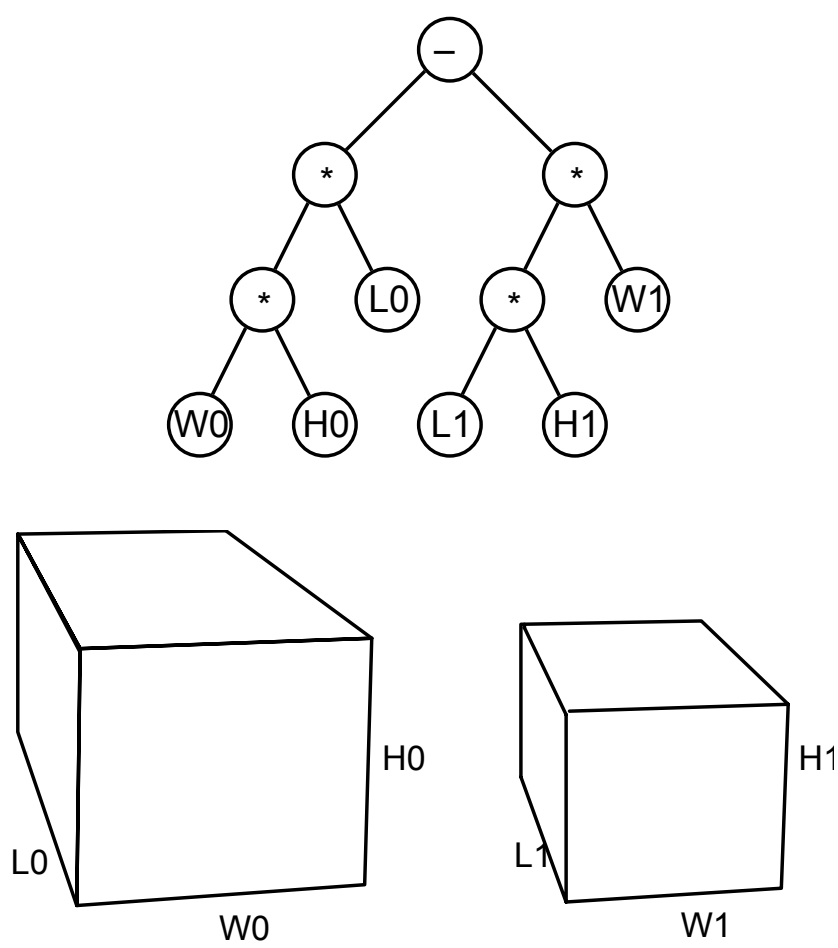


\section{AUTOMATICALLY DEFINED FUNCTIONS (ADFs, SUBROUTINES)}

AN OVERALL COMPUTER PROGRAM CONSISTING OF ONE FUNCTIONDEFINING BRANCH (ADF, SUBROUTINE) AND ONE RESULTPRODUCING BRANCH (MAIN PROGRAM)

(progn

(defun volume (arg0 arg1 arg2) (values

(* $\arg 0(* \arg 1 \arg 2))))$

(values (- (volume LO WO HO) (volume L1 W1 H1))))

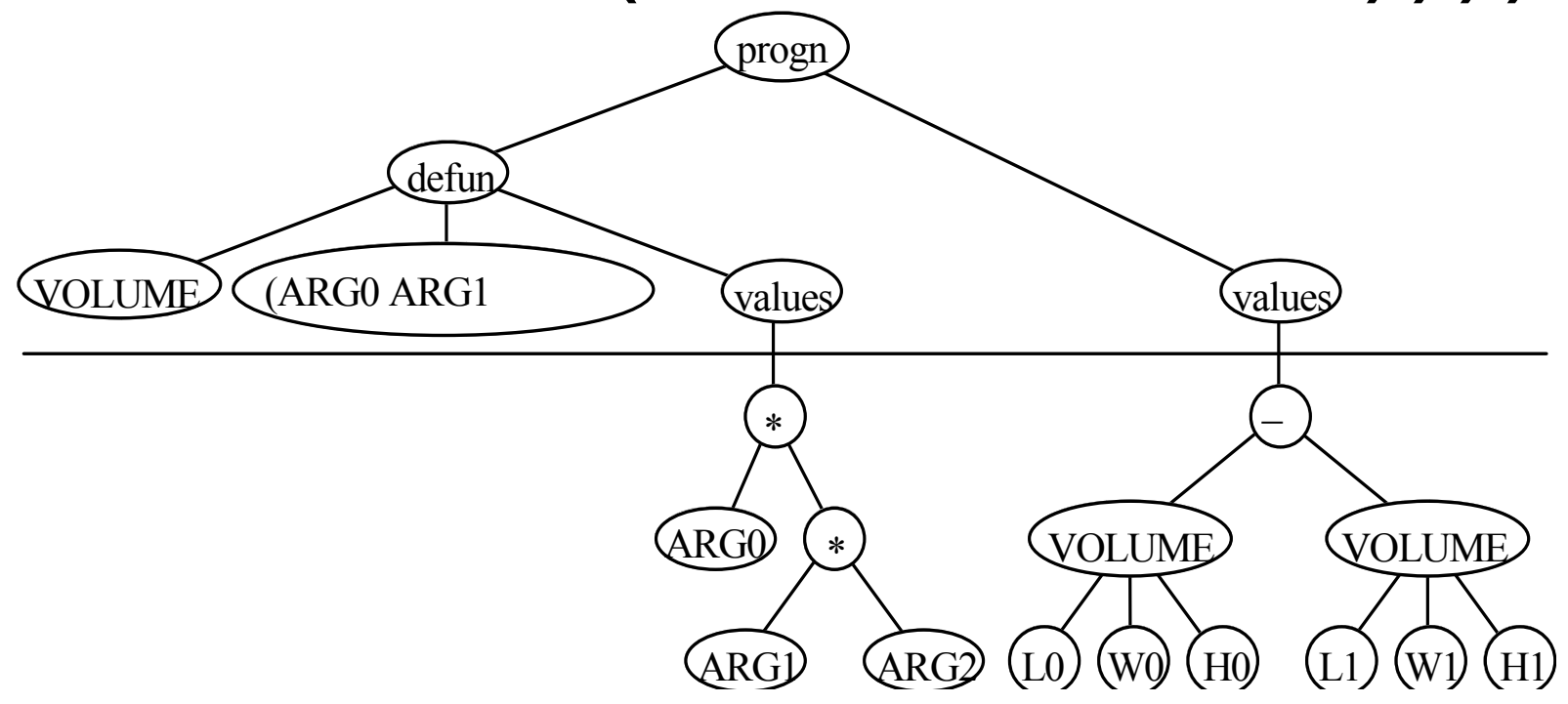




\section{AUTOMATICALLY DEFINED FUNCTIONS (ADFs, SUBROUTINES)}

IF WE ADD TWO NEW VARIABLES FOR VOLUME ( $V_{0}$ AND $\left.V_{1}\right)$, THE 6DIMENSIONAL NON-LINEAR REGRESSION PROBLEM BECOMES AN 8-DIMENSIONAL PROBLEM

\begin{tabular}{|l|l|l|l|l|l|l|l|l|l|}
\hline $\begin{array}{l}\text { Fitness } \\
\text { case }\end{array}$ & $L_{0}$ & $W_{0}$ & $H_{0}$ & $L_{1}$ & $W_{1}$ & $H_{1}$ & $\boldsymbol{V}_{\mathbf{0}}$ & $\boldsymbol{V}_{\mathbf{1}}$ & $\boldsymbol{D}$ \\
\hline $\mathbf{1}$ & 3 & 4 & 7 & 2 & 5 & 3 & $\mathbf{8 4}$ & $\mathbf{3 0}$ & $\mathbf{5 4}$ \\
\hline $\mathbf{2}$ & 7 & 10 & 9 & 10 & 3 & 1 & $\mathbf{6 3 0}$ & $\mathbf{3 0}$ & $\mathbf{6 0 0}$ \\
\hline $\mathbf{3}$ & 10 & 9 & 4 & 8 & 1 & 6 & $\mathbf{3 6 0}$ & $\mathbf{4 8}$ & $\mathbf{3 1 2}$ \\
\hline $\mathbf{4}$ & 3 & 9 & 5 & 1 & 6 & 4 & $\mathbf{1 3 5}$ & $\mathbf{2 4}$ & $\mathbf{1 1 1}$ \\
\hline $\mathbf{5}$ & 4 & 3 & 2 & 7 & 6 & 1 & $\mathbf{2 4}$ & $\mathbf{4 2}$ & $\mathbf{- 1 8}$ \\
\hline $\mathbf{6}$ & 3 & 3 & 1 & 9 & 5 & 4 & $\mathbf{9}$ & $\mathbf{1 8 0}$ & $\mathbf{- 1 7 1}$ \\
\hline $\mathbf{7}$ & 5 & 9 & 9 & 1 & 7 & 6 & $\mathbf{4 0 5}$ & $\mathbf{4 2}$ & $\mathbf{3 6 3}$ \\
\hline $\mathbf{8}$ & 1 & 2 & 9 & 3 & 9 & 2 & $\mathbf{1 8}$ & $\mathbf{5 4}$ & $\mathbf{- 3 6}$ \\
\hline $\mathbf{9}$ & 2 & 6 & 8 & 2 & 6 & 10 & $\mathbf{9 6}$ & $\mathbf{1 2 0}$ & $\mathbf{- 2 4}$ \\
\hline $\mathbf{1 0}$ & 8 & 1 & 10 & 7 & 5 & 1 & $\mathbf{8 0}$ & $\mathbf{3 5}$ & $\mathbf{4 5}$ \\
\hline
\end{tabular}

- However, the problem can now be approached as a 2dimensional LINEAR regression problem. 


\section{AUTOMATICALLY DEFINED FUNCTIONS (ADFs, SUBROUTINES)}

\section{TOP-DOWN VIEW OF THREE STEP HIERARCHICAL PROBLEM-SOLVING PROCESS}

\section{DIVIDE AND CONQUER}

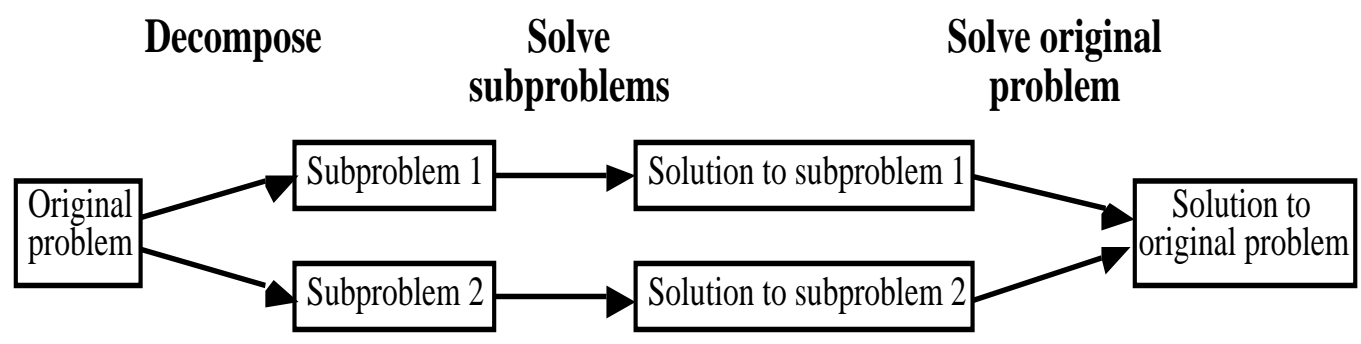

- Decompose a problem into subproblems

- Solve the subproblems

- Assemble the solutions of the subproblems into a solution for the overall problem 


\section{AUTOMATICALLY DEFINED FUNCTIONS (ADFs, SUBROUTINES)}

\section{BOTTOM-UP VIEW OF THREE STEP HIERARCHICAL PROBLEM-SOLVING PROCESS}

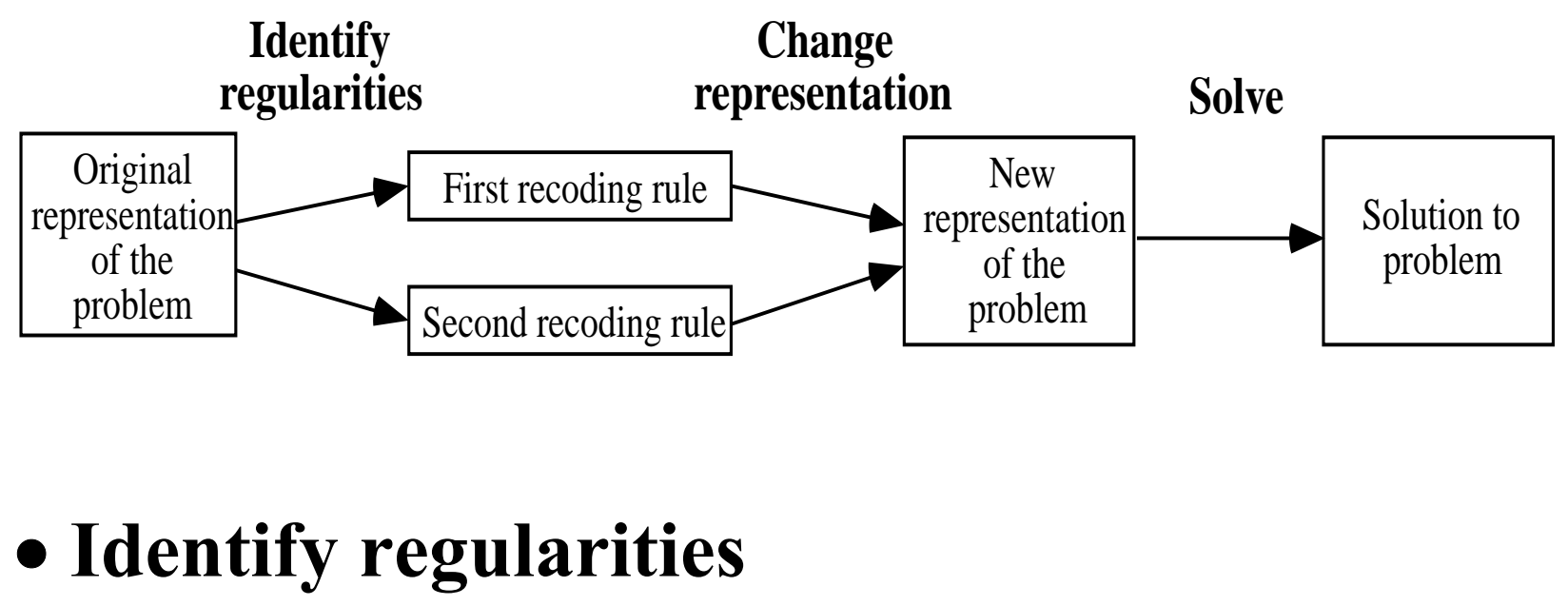

- Change the representation

- Solve the overall problem 


\section{AUTOMATICALLY DEFINED FUNCTIONS (ADFs, SUBROUTINES)}

- In generation 0, we create a population of programs, each consisting of a main result-producing branch (RPB) and one or more function-defining branches (automatically defined functions, ADFs, subroutines)

- Different ingredients for RPB and ADFs

- The terminal set of an ADF typically contains dummy arguments (formal parameters), such as ARG0, ARG1, ...

- The function set of the RPB contains ADF $0, \ldots$

- ADFs are private and associated with a particular individual program in the population

- The entire program is executed and evaluated for fitness

- Genetic operation of reproduction is the same as before

- Mutation operation starts (as before) by picking a mutation point from either RPB or an ADF and deleting the subtree rooted at that point. As before, a subtree is then grown at the point. The new subtree is composed of the allowable ingredients for that point - so that the result is a syntactically valid executable program.

- Crossover operation starts (as before) by picking a crossover point from either RPB or an ADF of one parent. The choice of crossover point in the second parent is then restricted (e.g., to the RPB or to the ADF) - so that when the subtrees are swapped, the result is a syntactically valid executable program. 


\section{AUTOMATICALLY DEFINED \\ FUNCTIONS (ADFS, SUBROUTINES)}

\section{MAIN POINTS FROM BOOK GENETIC PROGRAMMING II: AUTOMATIC DISCOVERY OF REUSABLE PROGRAMS (KOZA 1994)}

- ADFs work.

- ADFs do not solve problems in the style of human programmers.

- ADFs reduce the computational effort required to solve a problem.

- ADFs usually improve the parsimony of the solutions to a problem.

- As the size of a problem is scaled up, the size of solutions increases more slowly with ADFs than without them.

- As the size of a problem is scaled up, the computational effort required to solve a problem increases more slowly with ADFs than without them.

- The advantages in terms of computational effort and parsimony conferred by ADFs increase as the size of the problem is scaled up. 


\section{REUSE}

\section{MEMORY AND STORAGE}

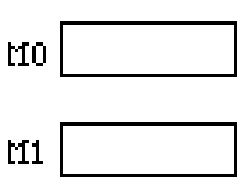

(A)

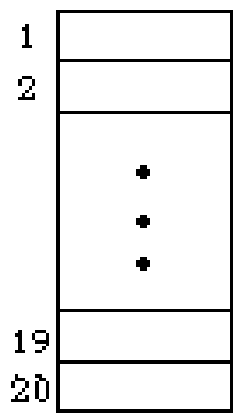

(B)

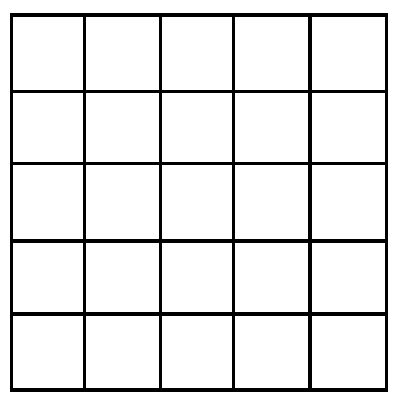

(C)

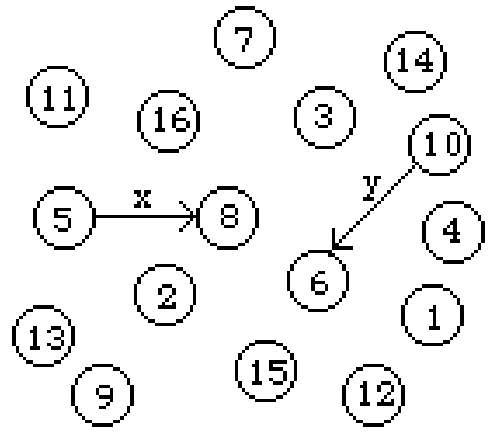

(D)

- (A) Settable (named) variables (Genetic Programming, Koza 1992) using setting (writing) functions (SETMO $X$ ) and (SETM1 $Y$ ) and reading by means of terminals $M O$ and M1.

- (B) Indexed memory similar to linear (vector) computer memory (Teller 1994) using (READ K) and (WRITE X K)

-(C) Matrix memory (Andre 1994)

- (D) Relational memory (Brave 1995, 1996)

\section{LANGDON'S DATA STRUCTURES}

- Stacks

- Queues

- Lists

- Rings 


\section{REUSE}

\section{AUTOMATICALLY DEFINED ITERATIONS (ADIS)}

- Overall program consisting of an automatically defined function $A D F 0$, an iteration-performing branch IPBO, and a result-producing branch $R P B O$.

- Iteration is over a known, fixed set

- protein or DNA sequence (of varying length

- time-series data

- two-dimensional array of pixels 


\section{REUSE}

\section{TRANSMEMBRANE SEGMENT IDENTIFICATION PROBLEM}

- Goal is to classify a given protein segment as being a transmembrane domain or non-transmembrane area of the protein

- Generation 20 - Run 3 - Subset-creating version

- in-sample correlation of 0.976

- out-of-sample correlation of 0.968

- out-of-sample error rate $1.6 \%$

(progn

(defun ADFO ()

(ORN (ORN (ORN (I?) (H?)) (ORN (P?) (G?))) (ORN (ORN

$(\operatorname{ORN}(Y ?) \quad(N ?)) \quad(\operatorname{ORN}(T ?) \quad(Q ?)))$ (ORN (A?) (H?))))))

(defun ADF1 ()

(values (ORN (ORN (ORN (A?) (I?)) (ORN (L?) (W?)))

(ORN (ORN (T?) (L?)) (ORN (T?) (W?))))))

(defun ADF2 ()

(values (ORN (ORN (ORN (ORN (ORN (D?) (E?)) (ORN (ORN (ORN (D?) (E?)) (ORN (ORN (T?) (W?)) (ORN (Q?)

$(\mathrm{D} ?))))$ (ORN (K?) (P?)))) (ORN (K?) (P?))) (ORN (T?)

$($ W?)) ) (ORN (ORN (E?) (A?)) (ORN (N?) (R?))))))

(progn (loop-over-residues

$\left.\left.\begin{array}{llll}(\operatorname{SETMO} & (+(-(\operatorname{ADF} 1) & (\mathrm{ADF} 2)) & (\operatorname{SETM} 3 \mathrm{MO})\end{array}\right)\right)$

(values (\% (\% M3 M0) (\% ( $\%$ (\% $(-$ L -0.53$)$ (* M0

M0) ) (+ (\% (\% M3 M0) ( $\%$ (+ MO M3) (\% M1 M2))) M2)) (\% M3 MO) )) )) ) 


\section{REUSE}

\section{EXAMPLE OF A PROGRAM WITH A FOUR-BRANCH AUTOMATICALLY DEFINED LOOP (ADLO) AND A RESULT- PRODUCING BRANCH}

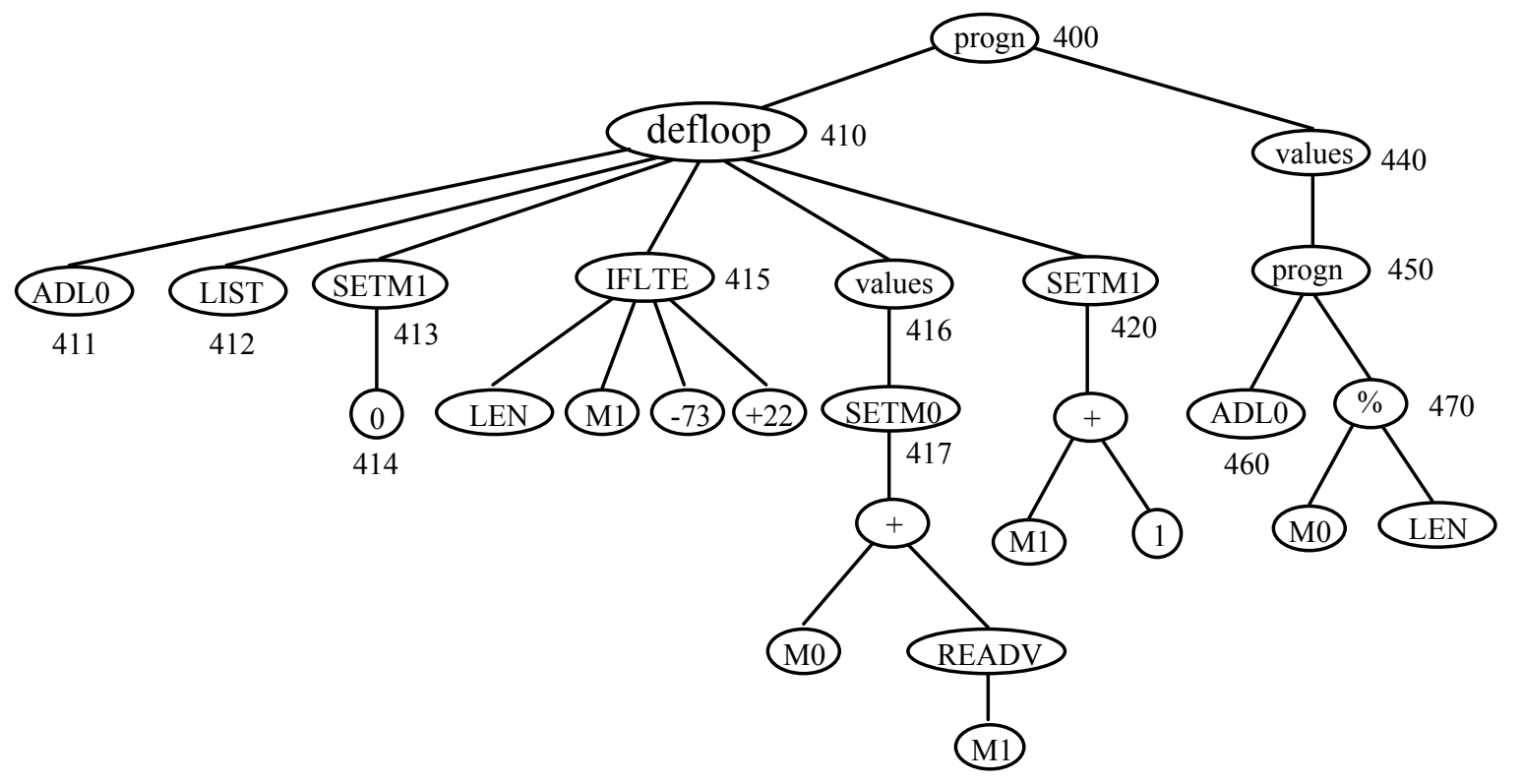




\section{REUSE}

\section{AUTOMATICALLY DEFINED RECURSION (ADRO) AND A RESULT- PRODUCING BRANCH}

- a recursion condition branch, $\mathrm{RCB}$

- a recursion body branch, $R B B$

- a recursion update branch, RUB

- a recursion ground branch, RGB

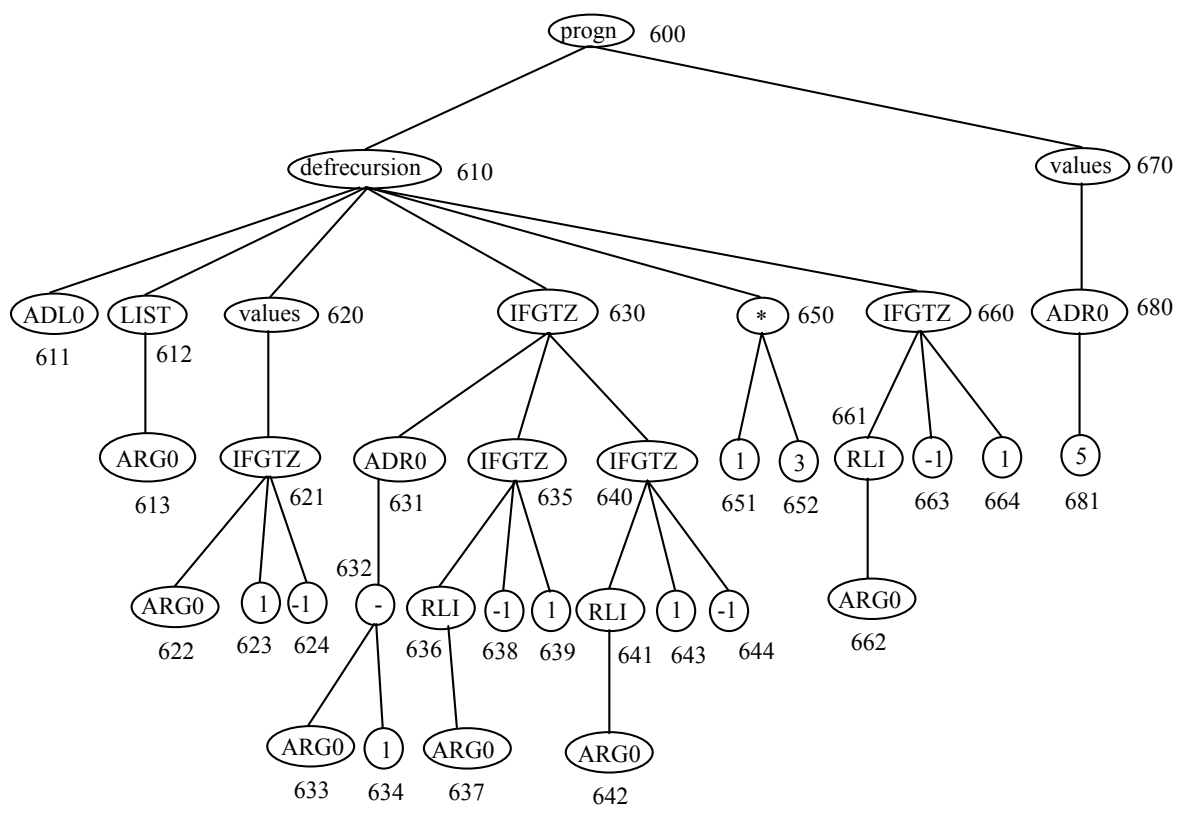




\section{GP TECHNIQUES}

- control structures involving multiple result-producing branches (Luke and Spector 1996a Bennett 1996a Svingen 1997)

- adaptive self-modifying ontogenetic genetic programming (Spector and Stoffel 1996a 1996b)

- cultural storage and transmission (Spector and Luke 1996a 1996b)

- hierarchical problem solving (Rosca and Ballard 1994a 1994b; Rosca 1995; Rosca 1997)

- modules (Angeline and Pollack 1993 1994; Angeline 1993 1994; Kinnear 1994b)

- logic grammars (Wong and Leung 1995a 1995b 1995c 1995d 1995e 1995f 1997)

- cellular encoding (developmental genetic programming) for evolving neural networks (Gruau 1992a 1992b 1993 1994a 1994b; Gruau and Whitley 1993; Esparcia-Alcazar and Sharman 1997)

- developmental methods for evolving finite automata using genetic programming (Brave 1996a)

- developmental methods for shape optimization (Kennelly 1997)

- evolving graphs and networks (Luke and Spector 1996b)

- using a grammar to represent bias and background knowledge (Whigham 1995a 1995b 1996)

- developmental methods for fuzzy logic systems (Tunstel and Jamshidi 1996) 


\section{GP TECHNIQUES — CONTINUED}

- diploidy and dominance (Greene 1997a 1997b)

- Turing completeness of genetic programming (Teller 1994c; Nordin and Banzhaf 1995)

- evolution of chemical topological structures (Nachbar 1997 1998)

- interactive fitness measures (Poli and Cagnoni 1997;) and in particular in graphics and art (Sims 1991a 1991b 1992a 1992b 1993)

- variations in crossover operations (Poli and Langdon 1997)

- distributed processes and multi-agent systems (Haynes Sen Schoenefeld and Wainwright 1995; Ryan 1995; Luke and Spector 1996a; Iba 1996; Iba Nozoe and Ueda 1997; Qureshi 1996; Crosbie and Spafford 1995)

- complexity-based fitness measures using minimum description length (Iba Kurita de Garis and Sato 1993; Iba deGaris and Sato 1994)

- co-evolution (Reynolds 1994c)

- steady state genetic programming (Reynolds 1993 1994a 1994b)

- use of noise in fitness cases (Reynolds 1994d)

- balancing parsimony and accuracy (Zhang and Muhlenbein 19931994 1995; Blickle 1997)

- automatically defined features using genetic algorithms in conjunction with genetic programming (Andre 1994a) - grammatical evolution (Conor Ryan and Michael O'Neill) 


\section{GP TECHNIQUES - CONTINUED}

- graphical program structures and neural programming (Teller and Veloso 1996, 1997; Teller 1998; Poli 1997a, 1997b)

- automatically defined macros (ADMs) for simultaneous evolution of programs and their control structures (Spector 1996)

- libraries (Koza 1990a; Koza and Rice 1991; Koza 1992a, section 6.5.4; Angeline and Pollack 1993, 1994; Angeline 1993, 1994; Kinnear 1994b)

- strong typing (Montana 1995; Montana and Czerwinski 1996; Janikow 1996; Yu and Clack 1997a) and constrained syntactic structures (Koza 1992a)

- explicit pointers (Andre 1994c)

- evolution of machine code (Nordin 1994, 1997) and linear genomes (Banzhaf, Nordin, Keller, and Francone 1998) 


\section{ARCHITECTURE-ALTERING OPERATIONS}

\section{PROTEIN ALIGNMENT OF "A" AND "B" PROTEINS}

First.protein Second.protein

First.protein Second.protein

First.protein Second.protein

First.protein Second.protein

First.protein Second.protein

First.protein second.protein
MRIKFLVVLA VI LFAHYAS ASGMGGDKKP KDAPKPKDAP KPKAVKPVBA MRIKFLVVLA VIFLLAHYAS ASGMGGDKKP KDAPKPKDAP KPKFVKPVBA

FSSEYEIEVI KHQKEKTEKK E⿵ DSSEYEIEVI KHQKEKTEKK EK 4 KKAHVEI IKKIKNKEKK EPCSEIMRIO

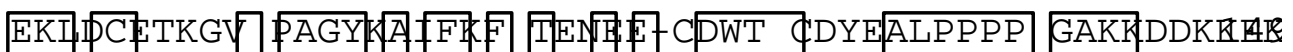

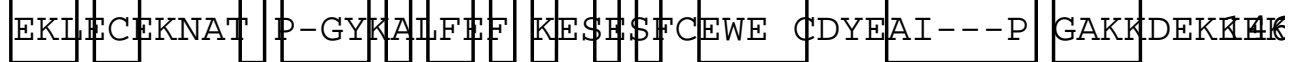

IVK KYVKYLKPPK EKPP KRPRKE CSGEKVIKFQ NCLVKIRGLI AFGDKTKN⿴囗十

KKFAKLVQGK QKKGAKKAKG G4KAAPKPGH RPGPK-Я--ф ADKP---Z3؛

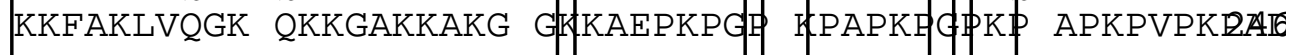

-- KDAKK

244 KHKDAKK 


\section{ARCHITECTURE-ALTERING OPERATIONS}

\section{PROGRAM WITH 1 TWO-ARGUMENT AUTOMATICALLY DEFINED FUNCTION (ADF0) AND 1 RESULT-PRODUCING BRANCH - ARGUMENT MAP OF $\{2\}$}

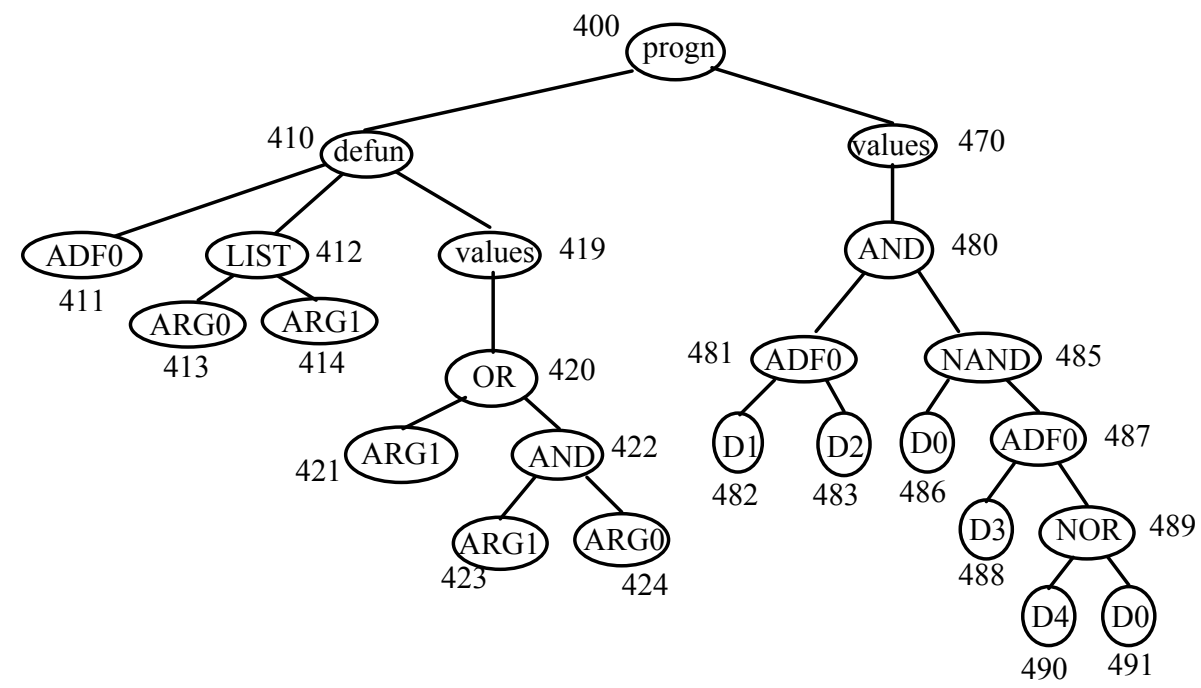




\section{ARCHITECTURE-ALTERING OPERATIONS}

\section{PROGRAM WITH ARGUMENT MAP OF $\{2,2\}$ CREATED USING THE OPERATION OF BRANCH DUPLICATION}

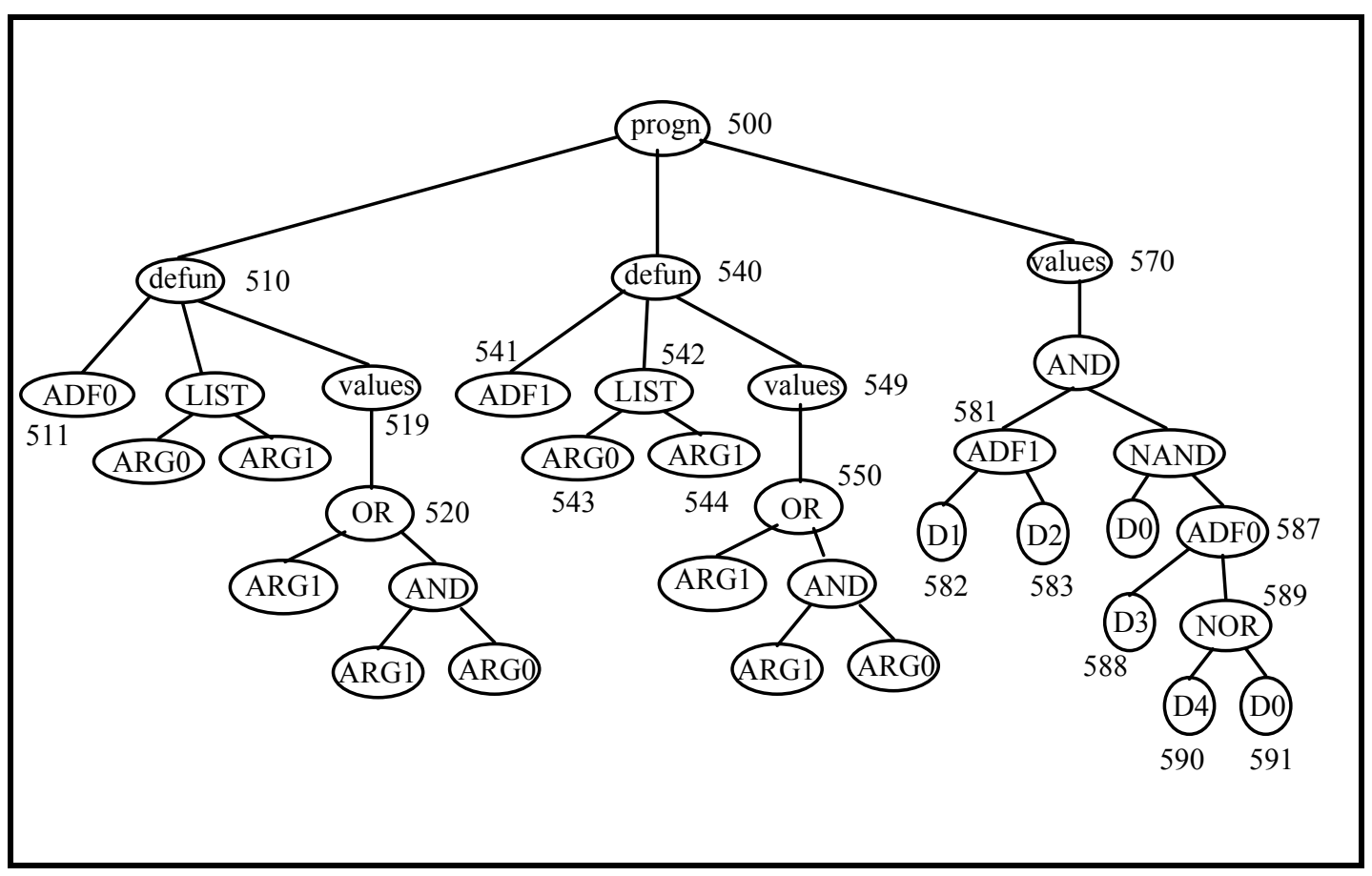




\section{ARCHITECTURE-ALTERING OPERATIONS}

\section{PROGRAM WITH ARGUMENT MAP OF \{3\} CREATED USING THE OPERATION OF ARGUMENT DUPLICATION}

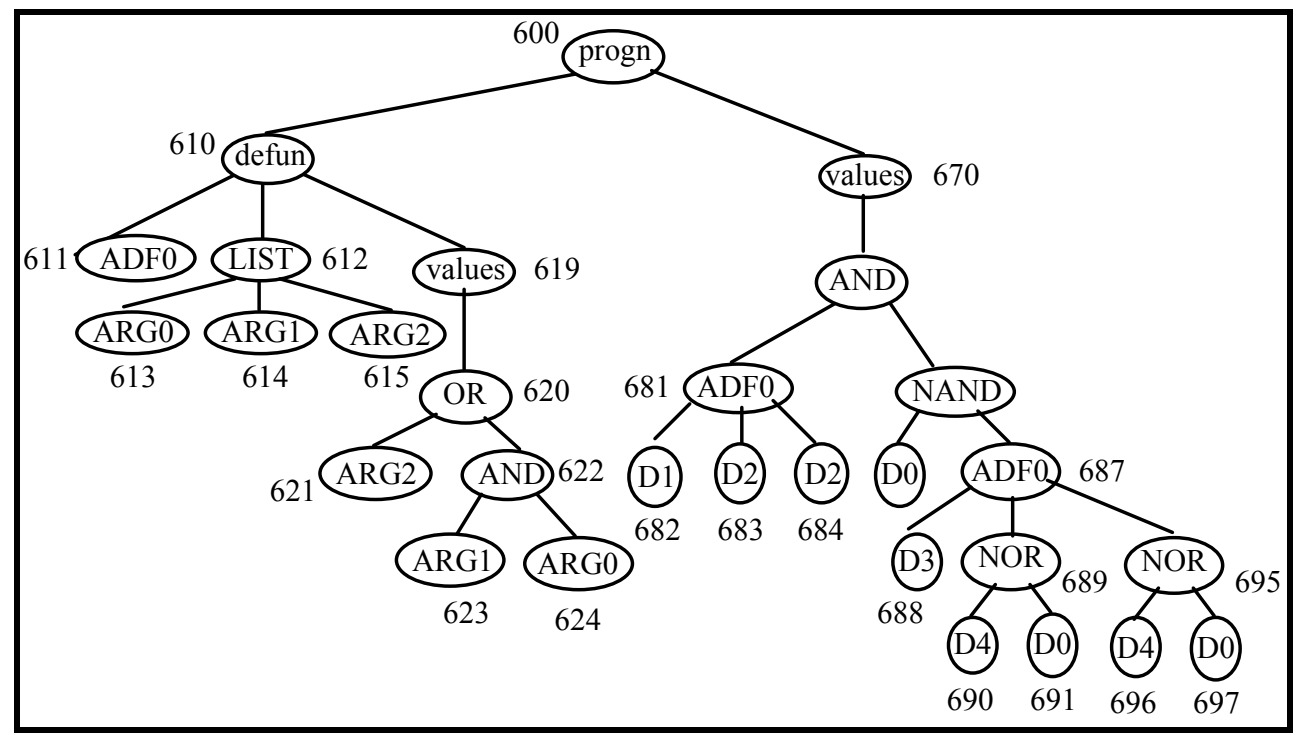




\section{ARCHITECTURE-ALTERING OPERATIONS}

\section{SPECIALIZATION - REFINEMENT - CASE SPLITTING}

- Branch duplication

- Argument duplication

- Branch creation

- Argument creation

\section{GENERALIZATION}

- Branch deletion

- Argument deletion 


\section{ATTRIBUTES OF A SYSTEM FOR AUTOMATICALLY CREATING COMPUTER PROGRAMS}

1 - Starts with "What needs to be done"

2 - Tells us "How to do it"

3 - Produces a computer program

4 - Automatic determination of program size

5 - Code reuse

6 - Parameterized reuse

7 - Internal storage

8 - Iterations, loops, and recursions

9 - Self-organization of hierarchies

10 - Automatic determination of program architecture

11 - Wide range of programming constructs

12 - Well-defined

13 - Problem-independent

14 - Wide applicability

15 - Scalable

16 - Competitive with human-produced results 


\section{ARCHITECTURE-ALTERING OPERATIONS}

\section{GENETIC PROGRAMMING PROBLEM SOLVER (GPPS) - VERSION 2.0}

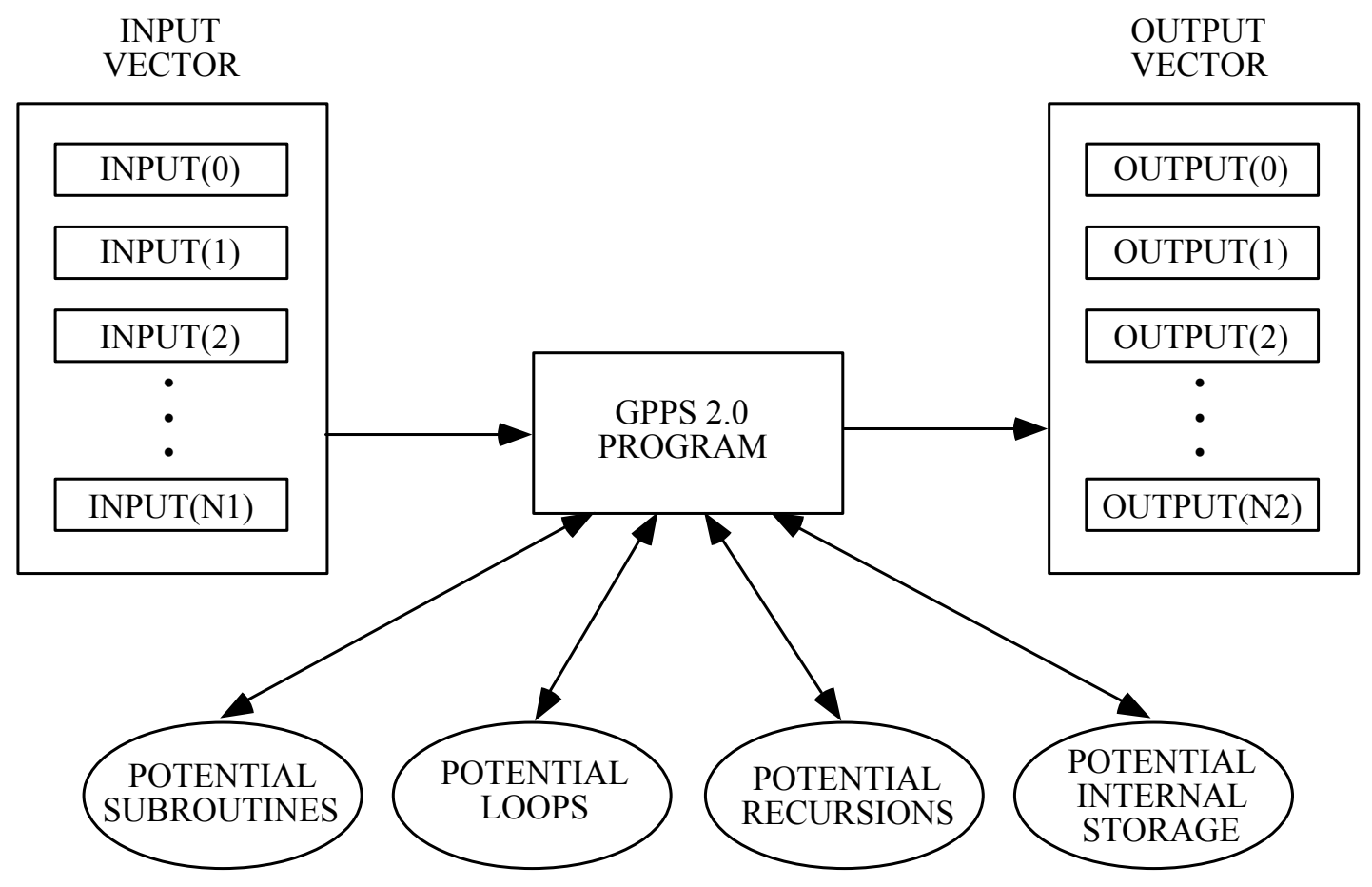




\section{IMPLEMENTATION OF GP IN \\ ASSEMBLY CODE - COMPILED \\ GENETIC PROGRAMMING SYSTEM \\ (NORDIN 1994)}

- Nordin, Peter. 1997. Evolutionary Program Induction of Binary Machine Code and its Application. Munster, Germany: Krehl Verlag.

- Opportunity to speed up GP that is done by slowly INTERPRETING GP program trees.

Instead of interpreting the GP program tree, EXECUTE this sequence of assembly code.

- Can identify small set of primitive functions that is useful for large group of problems, such as,,+- , $\frac{\circ}{\circ}$ and also use some conditional operations (IFLTE), some logical functions (AND, OR, XOR, XNOR) and perhaps others (e.g., SRL, SLI, SETHI from Sun 4).

- Then, generate random sequence of assembly code instructions at generation 0 from this small set of machine code instructions (referring to certain registers).

- If ADFs are involved, generate fixed header and footer of function and appropriate function call.

- Perform crossover possibly so as to preserve the integrity of subtrees.

- If ADFs are involved, perform crossover so as to preserve the integrity of the header and footer of function and the function call. 


\section{DESIGN OF QUANTUM COMPUTER CIRCUITS USING GP (SPECTOR ET AL.)}

- Spector, Lee, Barnum, Howard, and Bernstein, Herbert J. 1998. Genetic programming for quantum computers. In Koza, John R., Banzhaf, Wolfgang, Chellapilla, Kumar, Deb, Kalyanmoy, Dorigo, Marco, Fogel, David B., Garzon, Max H., Goldberg, David E., Iba, Hitoshi, and Riolo, Rick. (editors). 1998. Genetic Programming 1998: Proceedings of the Third Annual Conference. San Francisco, CA: Morgan Kaufmann. Pages 365 - 373.

- Spector, Lee, Barnum, Howard, and Bernstein, Herbert J. 1999. Quantum computing applications of genetic programming. In Spector, Lee, Langdon, William B., O'Reilly, Una-May, and Angeline, Peter (editors). 1999. Advances in Genetic Programming 3. Cambridge, MA: The MIT Press. Pages 135-160.

- Spector, Lee, Barnum, Howard, Bernstein, Herbert J., and Swamy, N. 1999. Finding a better-than-classical quantum AND/OR algorithm using genetic programming. In IEEE. Proceedings of 1999 Congress on Evolutionary Computation. Piscataway, NJ: IEEE Press. Pages 2239-2246.

- Barnum, H., Bernstein, H.J. and Spector, Lee. 2000. Quantum circuits for OR and AND of ORs. Journal of Physics A: Mathematical and General. 33 (45) 8047-8057. November 17, 2000).

- Spector, Lee, and Bernstein, Herbert J. 2003. Communication capacities of some quantum gates, discovered in part through genetic programming. In Shapiro, Jeffery H. and Hirota, Osamu (editors). Proceedings of the Sixth International Conference on Quantum Communication, Measurement, and Computing. Princeton, NJ: Rinton Press. Pages 500-503. 


\section{CELLULAR ENCODING (DEVELOPMENTAL GENETIC PROGRAMMING)}

- Gruau, Frederic. 1992b. Cellular Encoding of Genetic Neural Networks. Technical report 92-21. Laboratoire de l'Informatique du Parallélisme. Ecole Normale Supérieure de Lyon. May 1992.

- Also: Gruau 1992a 1992b 1993 1994a 1994b; Gruau and Whitley 1993; Esparcia-Alcazar and Sharman 1997)

- Applied by Gruau and Whitley (1995) to 2-pole-balancing problem

- Applied by Gruau to six-legged walking creature

- Applied by Brave $(1995,1996)$ to Finite Automata 


\section{AUTOMATIC PARALLELIZATION OF SERIAL PROGRAMS USING GP}

- Ryan, Conor. 1999. Automatic Re-engineering of Software Using Genetic Programming. Amsterdam: Kluwer Academic Publishers.

- Start with working serial computer program (embryo)

- GP program tree contains validity-preserving functions that modify the current program. That is, the functions in the program tree side-effect the current program.

- Execution of the complete GP program tree progressively modifies the current program

- Fitness is based on execution time on the parallel computer system 


\section{DEVELOPMENTAL GP}

\section{THE INITIAL CIRCUIT}

- Initial circuit consists of embryo and test fixture

- Embryo has modifiable wires (e.g., Z0 AND Z1)

- Test fixture has input and output ports and usually has source resistor and load resistor. There are no modifiable wires (or modifiable components) in the test fixture.

- Circuit-constructing program trees consist of

- Component-creating functions

- Topology-modifying functions

- Development-controlling functions

- Circuit-constructing program tree has one resultproducing branch for each modifiable wire in embryo of the initial circuit

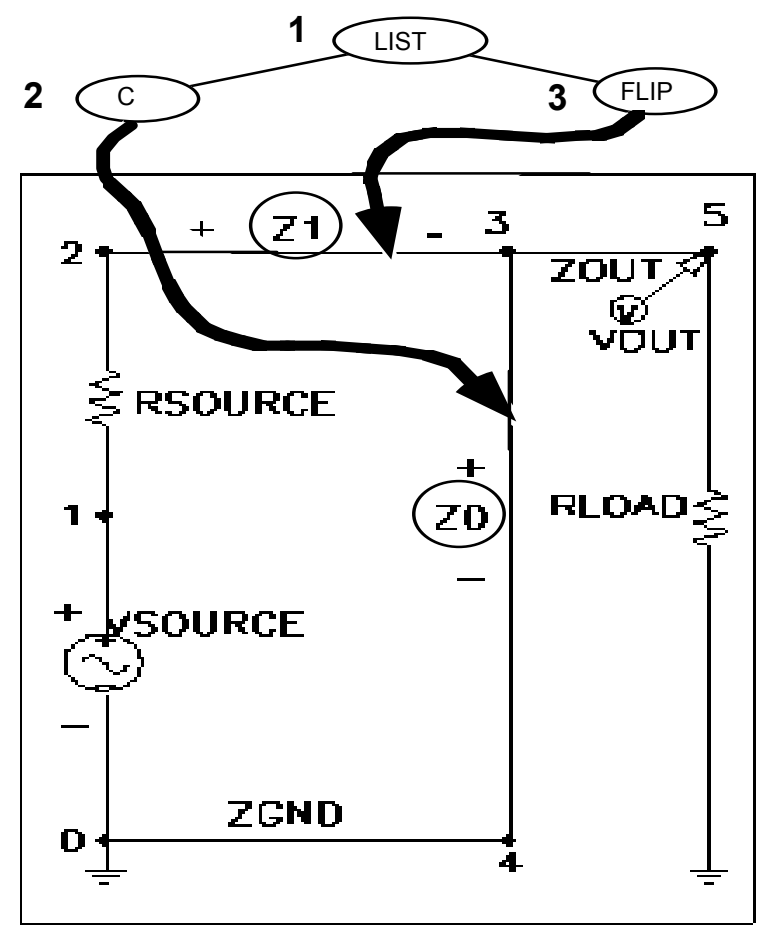




\section{DEVELOPMENTAL GP}

\section{DEVELOPMENT OF A CIRCUIT FROM A CIRCUIT-CONSTRUCTING PROGRAM TREE AND THE INITIAL CIRCUIT}

(LIST (C $(-0.963)(-\quad(-0.875$ -0.113 ) 0.880$)$ ) (series (flip end) (series (flip end) ( $L$ 0.277 end) end) ( $L$ ( -0.640 $0.749)(\mathrm{L}-0.123$ end)))) (flip $($ nop $(L-0.657$ end $)))))$

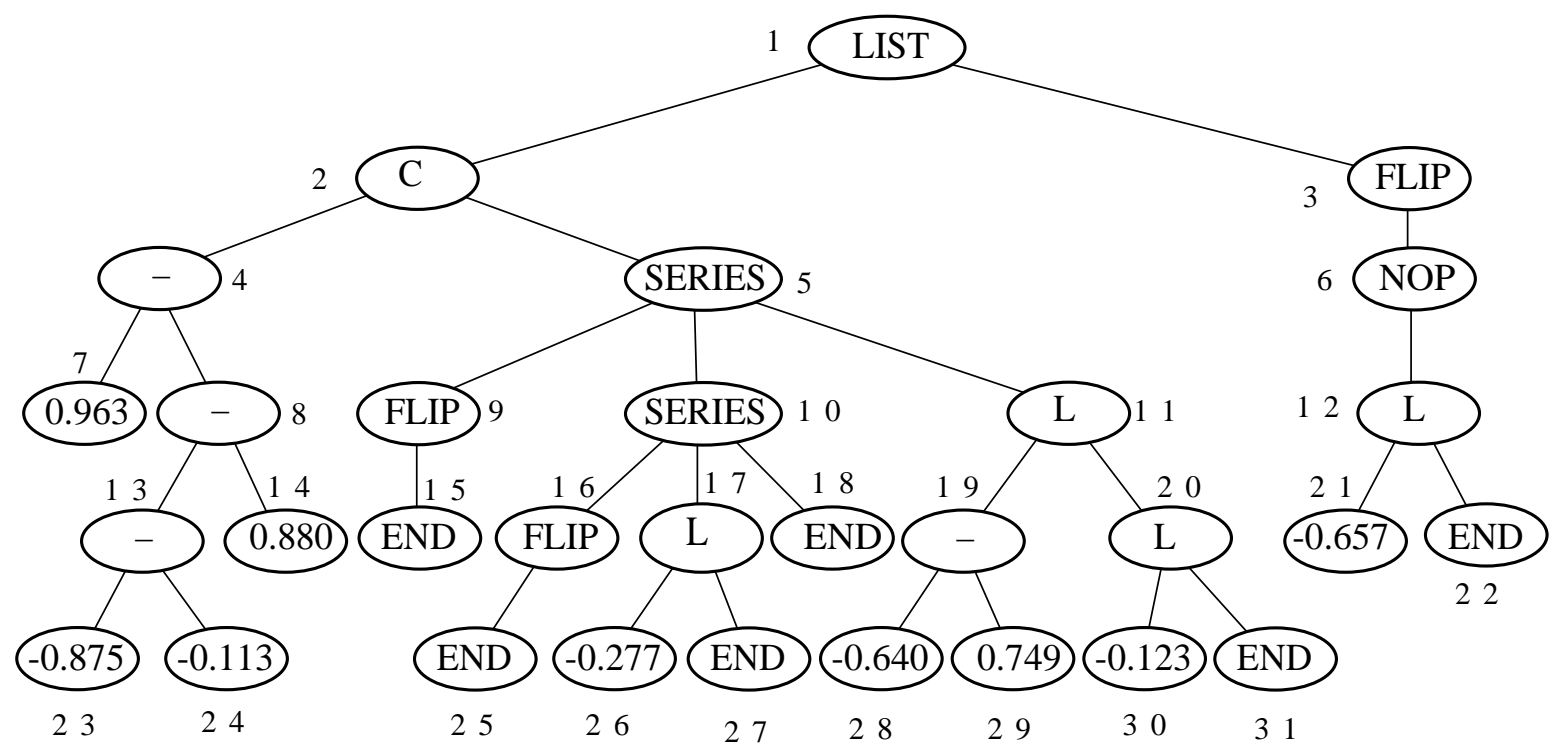




\section{DEVELOPMENTAL GP}

\section{RESULT OF THE C (2) FUNCTION}

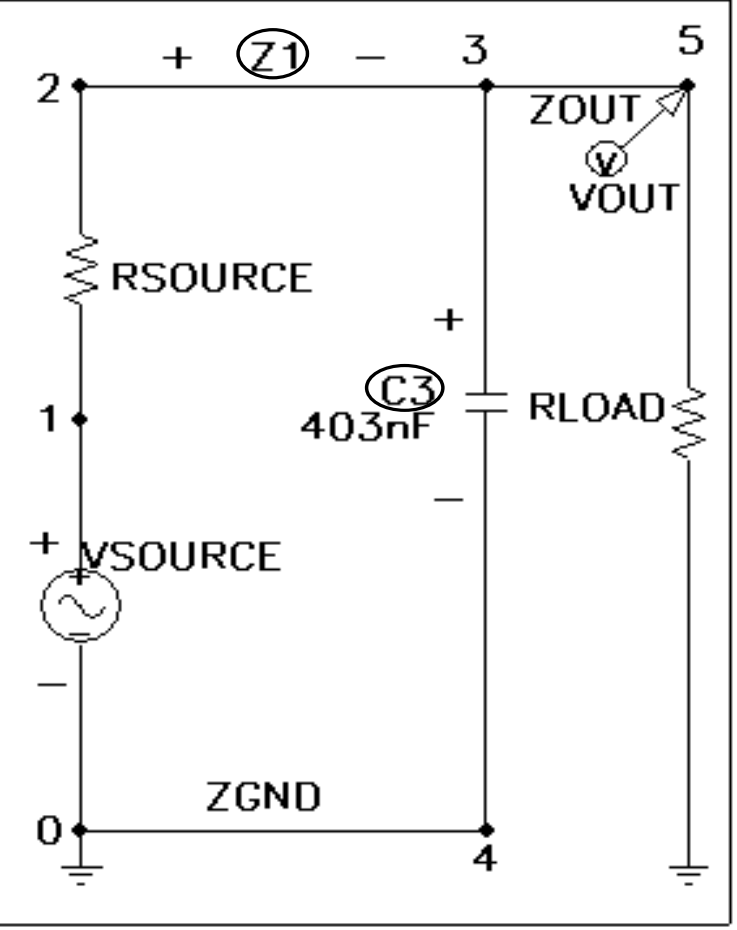

(IIST IC $(-0.963)(-\quad-0.875$

$-0.113) 0.880)$ ) (series (flip

end) (series (flip end) ( $L$ -

0.277 end) end) ( $\mathrm{L}(--0.640$

$0.749)(\mathrm{L}-0.123$ end $)))$ ) (flip

$($ nop $(L-0.657$ end) )) ))

NOTE: Interpretation of arithmetic value 


\section{DEVELOPMENTAL GP}

\section{RESULT OF SERIES (5) FUNCTION}

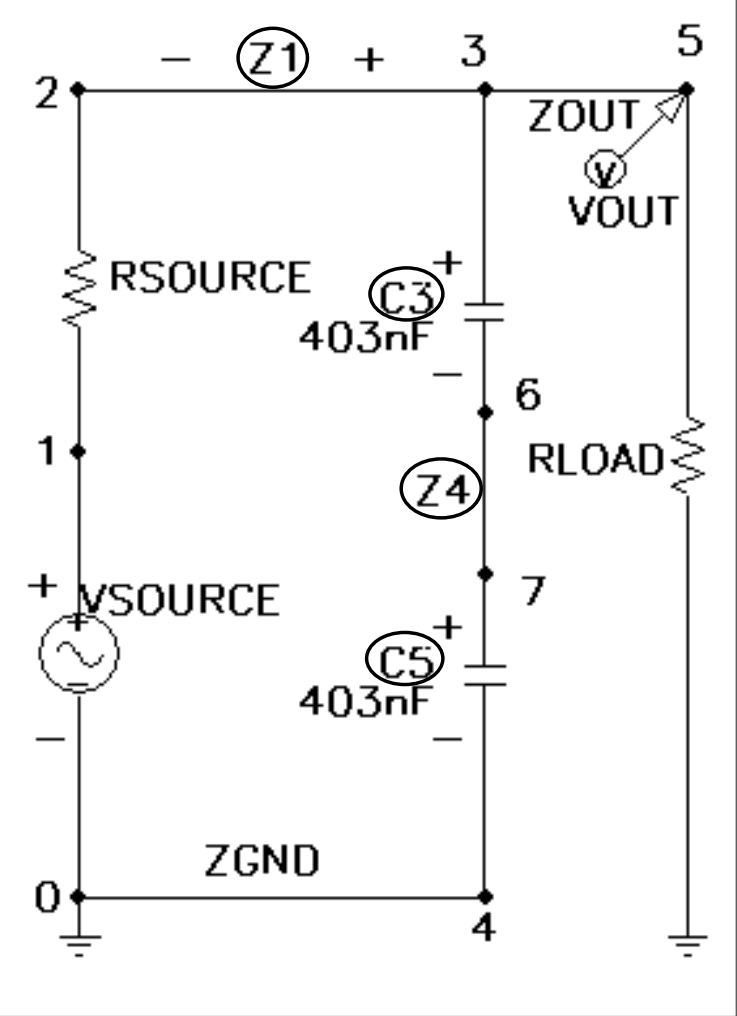

(LIST (C $(-0.963)(--0.875$

-0.113 ) 0.880$)$ ) (series (flip end) (series (flip end) ( $L$ 0.277 end) end) ( $\mathrm{L}(--0.640$ $0.749)(\mathrm{L}-0.123$ end $)))$ ) (flip $(\operatorname{nop}(\mathrm{L}-0.657$ end) )) )) 


\section{EVALUATION OF FITNESS OF A CIRCUIT}
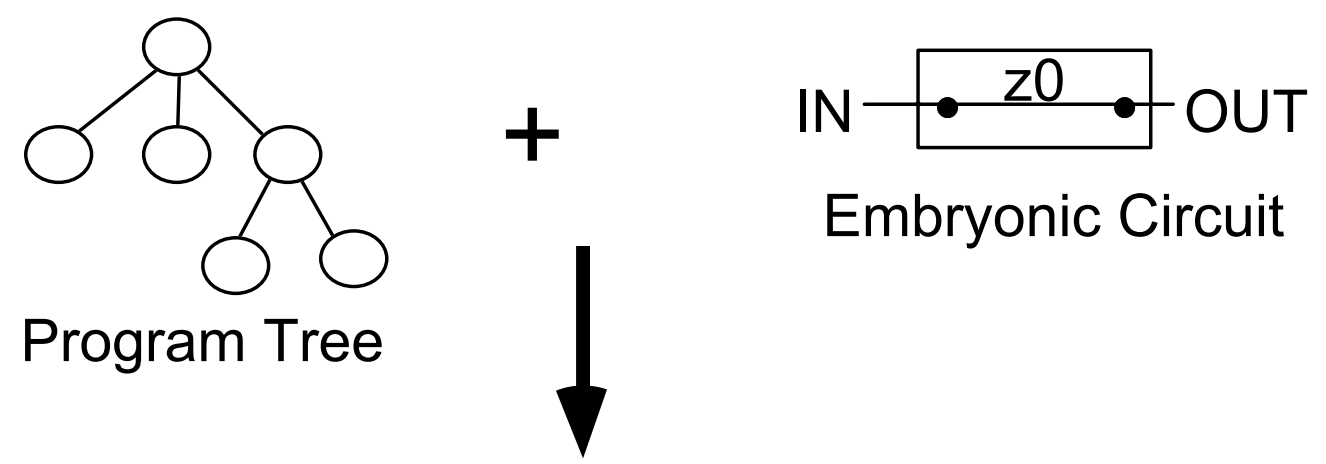

Embryonic Circuit

Fully Designed Circuit (NetGraph)

Circuit Netlist (ascii)

$\downarrow$

Circuit Simulator (SPICE)

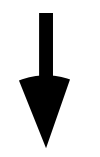

Circuit Behavior (Output)

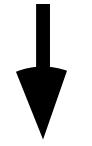

Fitness 


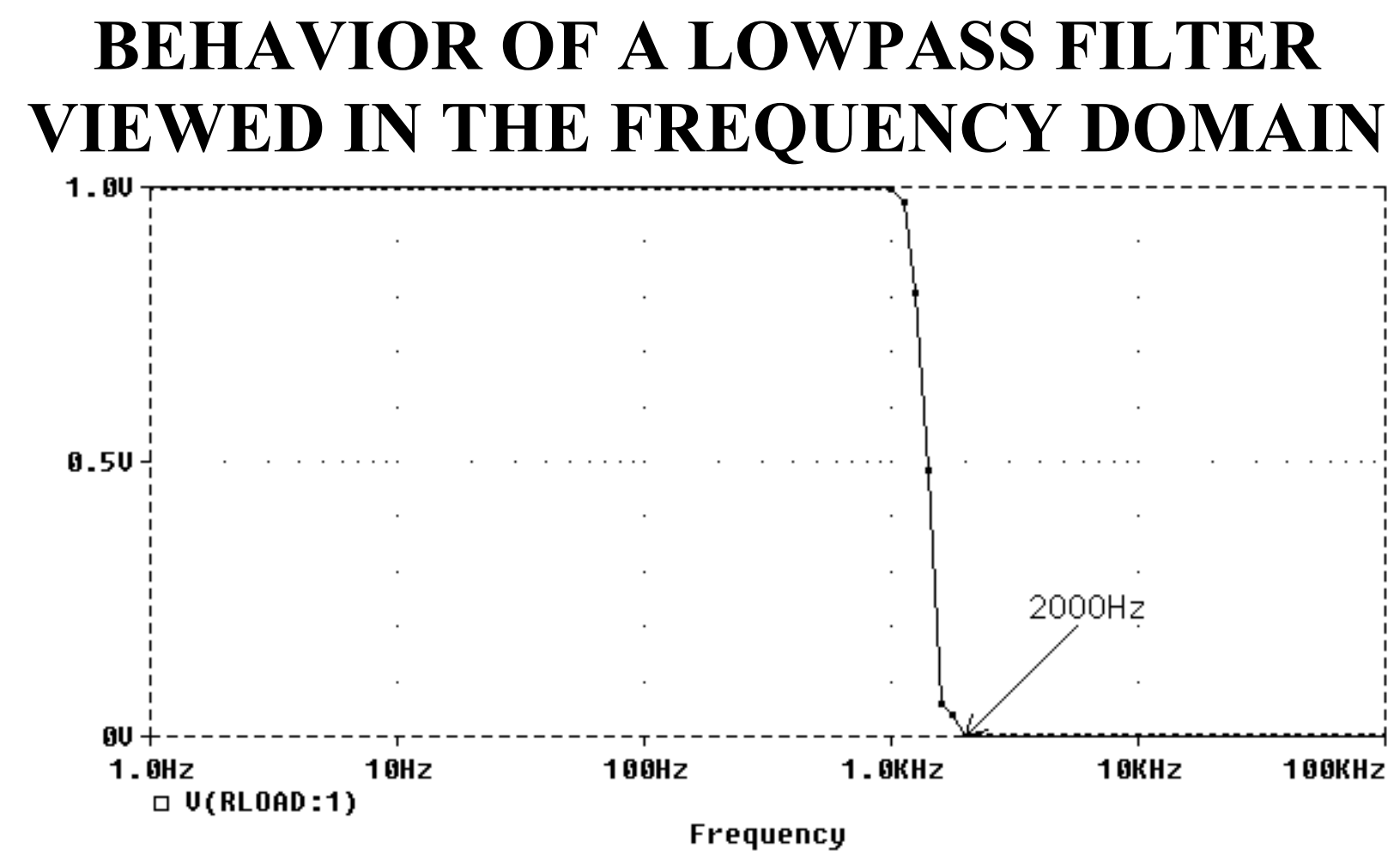

- Examine circuit's behavior for each of 101 frequency values chosen over five decades of frequency (from $1 \mathrm{~Hz}$ to $100,000 \mathrm{~Hz}$ ) with each decade divided into 20 parts (using a logarithmic scale). The fitness measure

- does not penalize ideal values

- slightly penalizes acceptable deviations

- heavily penalizes unacceptable deviations

- Fitness is sum $\boldsymbol{F}(\boldsymbol{t})=\sum_{i=0}^{100}\left[W\left(f_{i}\right) d\left(f_{i}\right)\right]$

- $f(i)$ is the frequency of fitness case $i$

$\bullet d(x)$ is the difference between the target and observed values at frequency of fitness case $i$

- $W(y, x)$ is the weighting at frequency $x$ 


\section{TABLEAU - LOWPASS FILTER (WITHOUT ADFS OR ARCHITECTURE- ALTERING OPERATIONS)}

\begin{tabular}{|c|c|}
\hline Objective: & $\begin{array}{l}\text { Design a lowpass filter composed of } \\
\text { inductors and capacitors with a } \\
\text { passband below } 1,000 \mathrm{~Hz} \text {, a stopband } \\
\text { above } 2,000 \mathrm{~Hz} \text {, a maximum allowable } \\
\text { passband deviation of } 30 \text { millivolts, and } \\
\text { a maximum allowable stopband } \\
\text { deviation of } 1 \text { millivolt. }\end{array}$ \\
\hline $\begin{array}{l}\text { Test fixture and } \\
\text { embryo: }\end{array}$ & $\begin{array}{l}\text { One-input, one-output initial circuit with } \\
\text { a source resistor, load resistor, and two } \\
\text { modifiable wires. }\end{array}$ \\
\hline $\begin{array}{l}\text { Program } \\
\text { architecture: }\end{array}$ & $\begin{array}{l}\text { Two result-producing branches, RPBO } \\
\text { and } R P B 1 \text { (i.e., one RPB per modifiable } \\
\text { wire in the embryo). }\end{array}$ \\
\hline $\begin{array}{l}\text { Initial function } \\
\text { set for the result- } \\
\text { producing } \\
\text { branches: }\end{array}$ & $\begin{array}{l}\text { For construction-continuing subtrees: } \\
\text { Fccs-rpb-initial = \{C, I, SERIES, } \\
\text { PARALLEL0, FLIP, NOP, TWO_GROUND, } \\
\text { TWO_VIA0, TWO_VIA1, TWO_VIA2, } \\
\text { TWO_VIA3, TWO_VIA4, TWO_VIA5, } \\
\text { TWO_VIA6, TWO_VIA7\}. } \\
\text { For arithmetic-performing subtrees: } \\
\text { Faps }=\{+,-\} .\end{array}$ \\
\hline $\begin{array}{l}\text { Initial terminal } \\
\text { set for the result- } \\
\text { producing } \\
\text { branches: }\end{array}$ & $\begin{array}{l}\text { For construction-continuing subtrees: } \\
\mathbf{T}_{\text {ccs-rpb-initial }}=\{\text { END }\} \text {. } \\
\text { For arithmetic-performing subtrees: } \\
\mathbf{T}_{\text {aps }}=\{\leftarrow \text { smaller-reals }\}\end{array}$ \\
\hline
\end{tabular}




\begin{tabular}{|c|c|}
\hline Fitness cases: & $\begin{array}{l}101 \text { frequency values in an interval of } \\
\text { five decades of frequency values between } \\
1 \mathrm{~Hz} \text { and } 100,000 \mathrm{~Hz} \text {. }\end{array}$ \\
\hline Raw fitness: & $\begin{array}{l}\text { Fitness is the sum, over the } 101 \text { sampled } \\
\text { frequencies (fitness cases), of the } \\
\text { absolute weighted deviation between the } \\
\text { actual value of the output voltage that is } \\
\text { produced by the circuit at the probe } \\
\text { point and the target value for voltage. } \\
\text { The weighting penalizes unacceptable } \\
\text { output voltages much more heavily than } \\
\text { deviating, but acceptable, voltages. }\end{array}$ \\
\hline $\begin{array}{l}\text { Standardized } \\
\text { fitness: }\end{array}$ & Same as raw fitness. \\
\hline Hits: & $\begin{array}{l}\text { The number of hits is defined as the } \\
\text { number of fitness cases (out of 101) for } \\
\text { which the voltage is acceptable or ideal } \\
\text { or that lie in the "don't care" band. }\end{array}$ \\
\hline Wrapper: & None. \\
\hline Parameters: & $\begin{array}{l}M=1,000 \text { to } 320,000 . G=1,001 . Q \\
=1,000 . D=64 . B=2 \% . N_{\text {rpb }}=2 . S_{\text {rpb }}= \\
200 .\end{array}$ \\
\hline $\begin{array}{l}\text { Result } \\
\text { designation: }\end{array}$ & Best-so-far pace-setting individual. \\
\hline $\begin{array}{l}\text { Success } \\
\text { predicate: }\end{array}$ & $\begin{array}{l}\text { A program scores the maximum number } \\
\text { (101) of hits. }\end{array}$ \\
\hline
\end{tabular}




\section{EVOLVED CAMPBELL FILTER \\ (7-RUNG LADDER)}

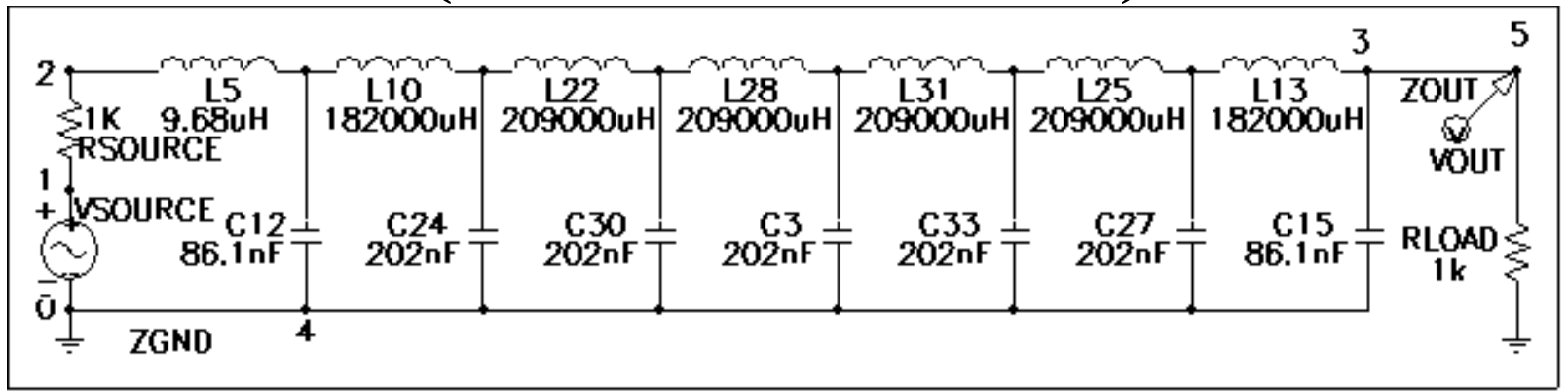

- This genetically evolved circuit infringes on U. S. patent 1,227,113 issued to George Campbell of American Telephone and Telegraph in 1917 (claim 2):

An electric wave filter consisting of a connecting line of negligible attenuation composed of a plurality of sections, each section including a capacity element and an inductance element, one of said elements of each section being in series with the line and the other in shunt across the line, said capacity and inductance elements having precomputed values dependent upon the upper limiting frequency and the lower limiting frequency of a range of frequencies it is desired to transmit without attenuation, the values of said capacity and inductance elements being so proportioned that the structure transmits with practically negligible attenuation sinusoidal currents of all frequencies lying between said two limiting frequencies, while attenuating and approximately extinguishing currents of neighboring frequencies lying outside of said limiting frequencies." 


\section{EVOLVED ZOBEL FILTER}

- Infringes on U. S. patent $1,538,964$ issued in 1925 to Otto Zobel of American Telephone and Telegraph Company for an " $M$-derived half section" used in conjunction with one or more "constant $K$ " sections.

- One $M$-derived half section (C2 and L11)

- Cascade of three symmetric T-sections

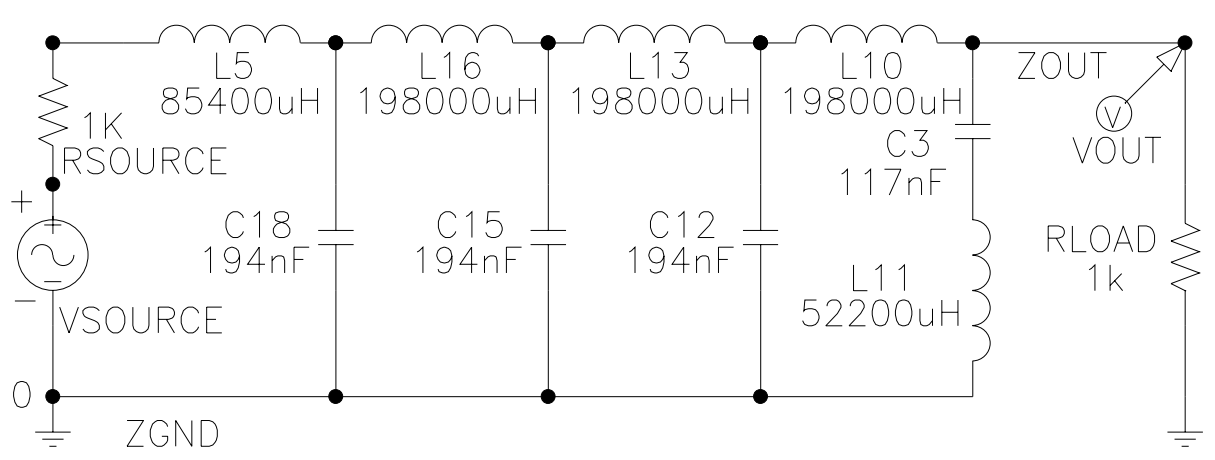




\section{GENETICALLY EVOLVED 10 DB AMPLIFIER FROM GENERATION 45}

\section{SHOWING THE VOLTAGE GAIN STAGE AND DARLINGTON EMITTER FOLLOWER SECTION}

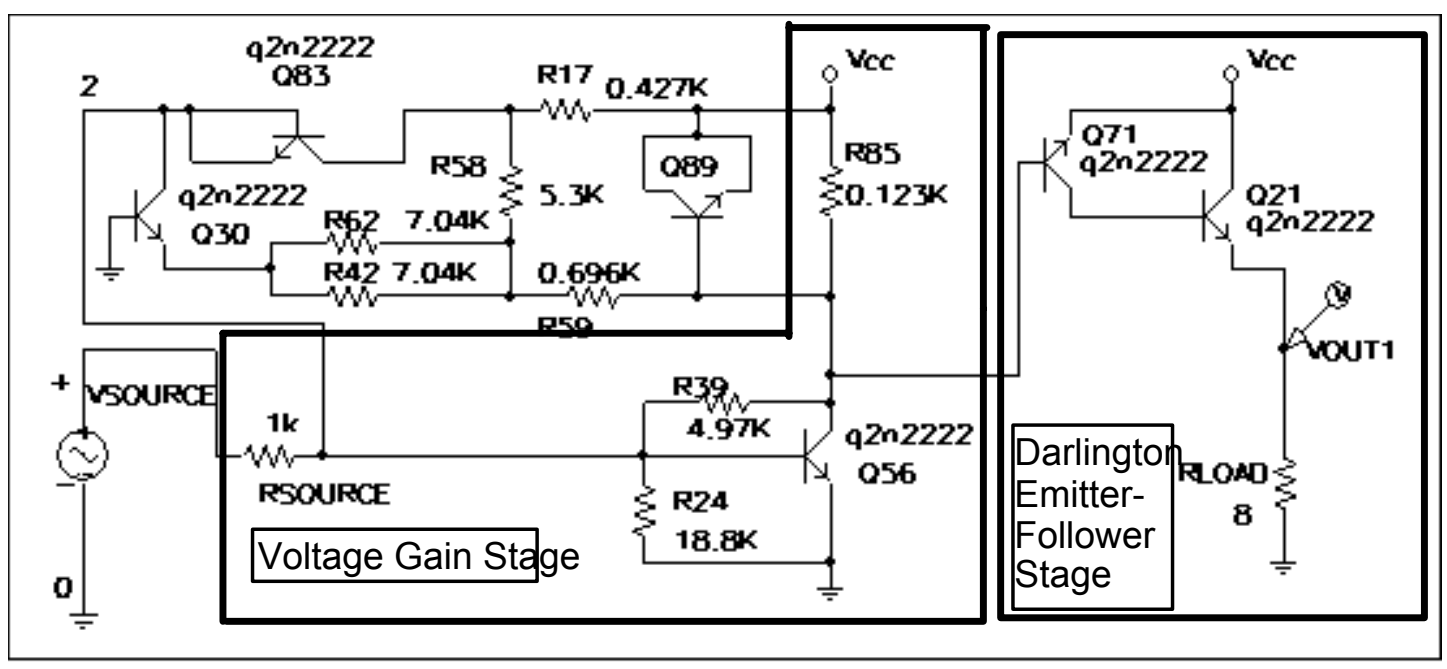


69

POST-2000 PATENTED INVENTIONS

HIGH CURRENT LOAD CIRCUIT BEST-OF-RUN FROM GENERATION 114

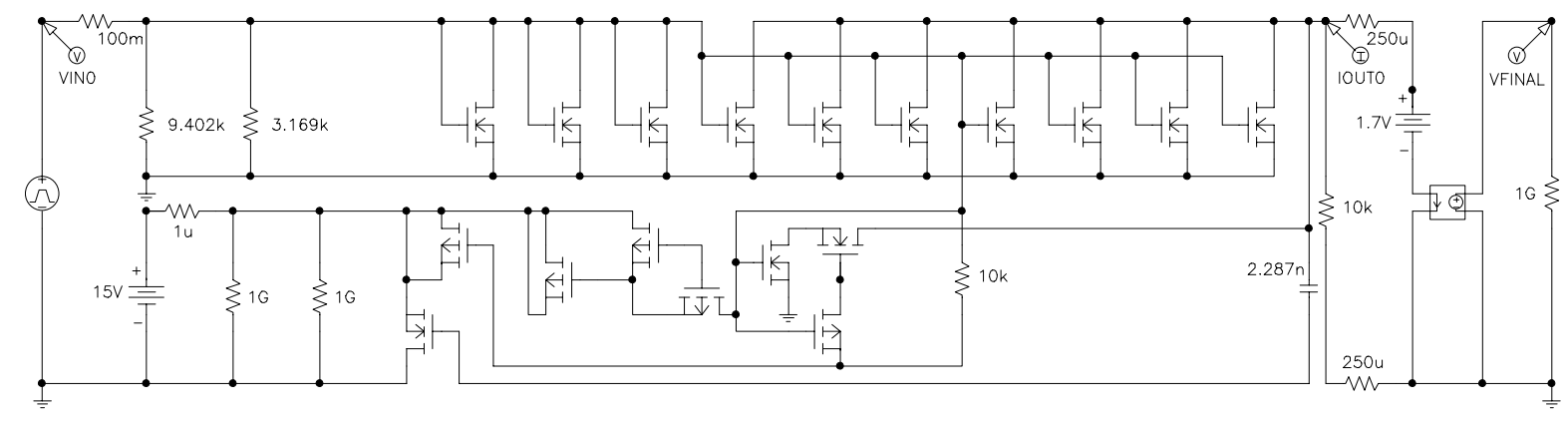




\section{POST-2000 PATENTED INVENTIONS}

\section{REGISTER-CONTROLLED CAPACITOR CIRCUIT}

\section{SMALLEST COMPLIANT FROM GENERATION 98}

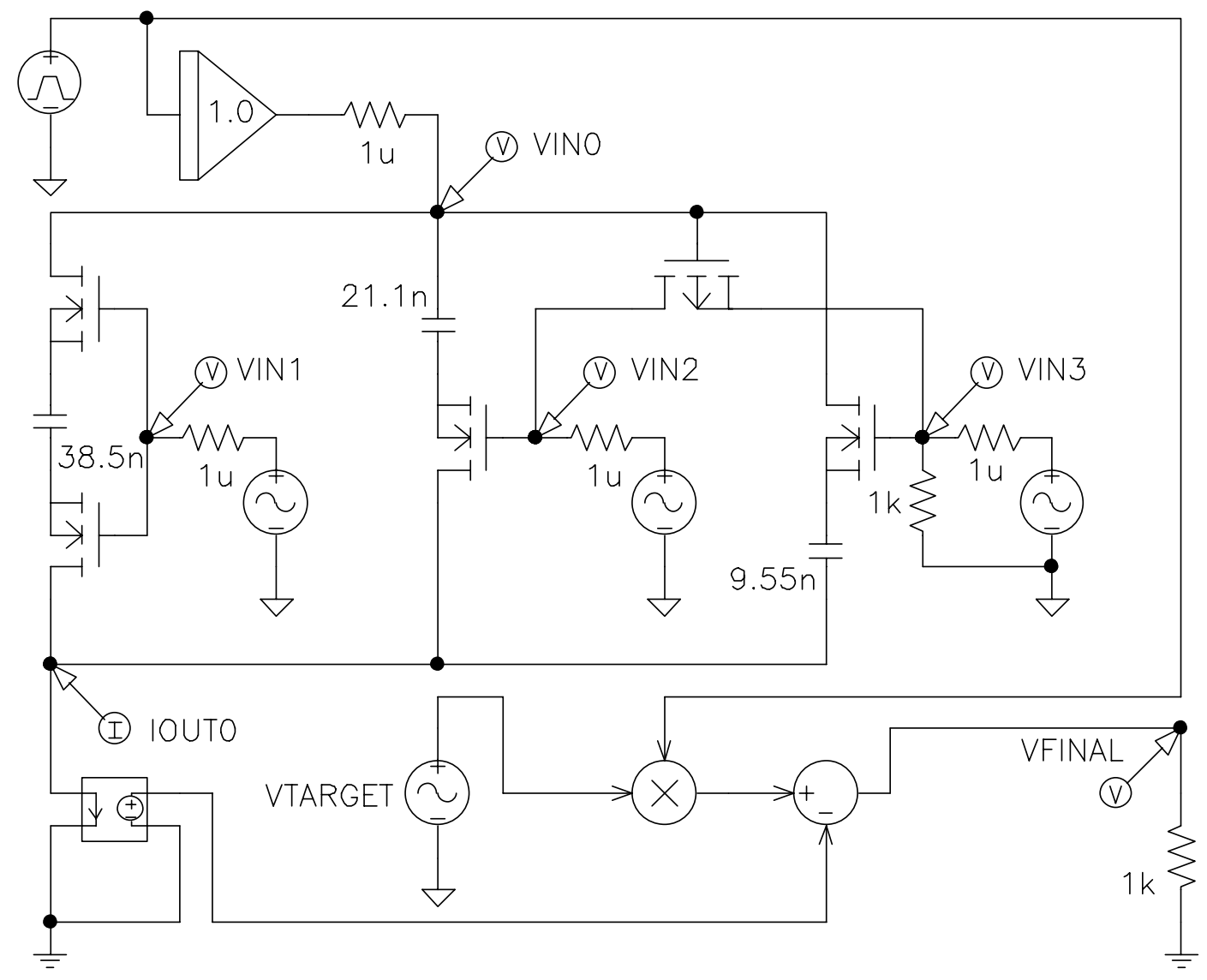




\section{POST-2000 PATENTED INVENTIONS}

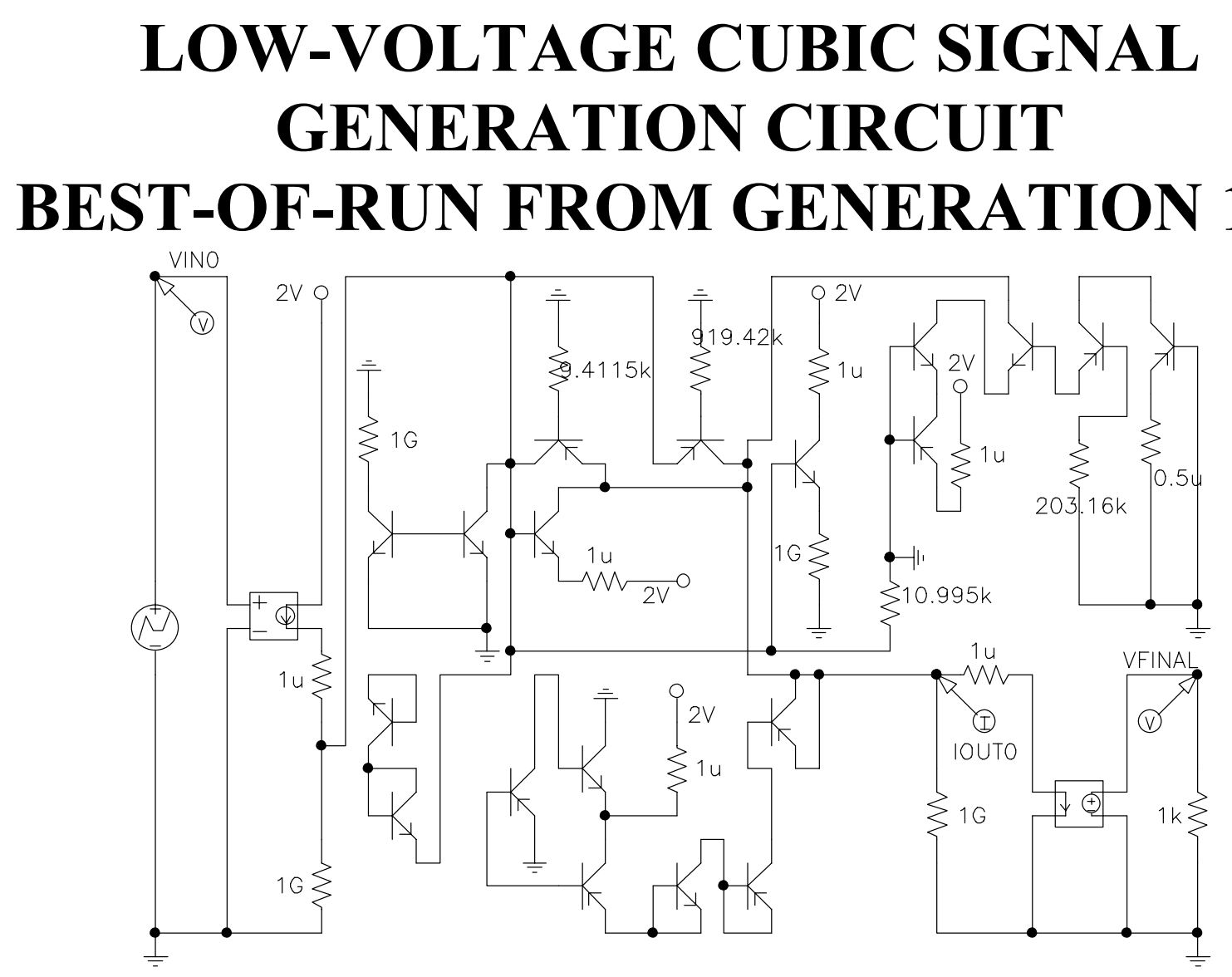




\section{POST-2000 PATENTED INVENTIONS}

\section{LOW-VOLTAGE BALUN CIRCUIT BEST EVOLVED FROM GENERATION 84}

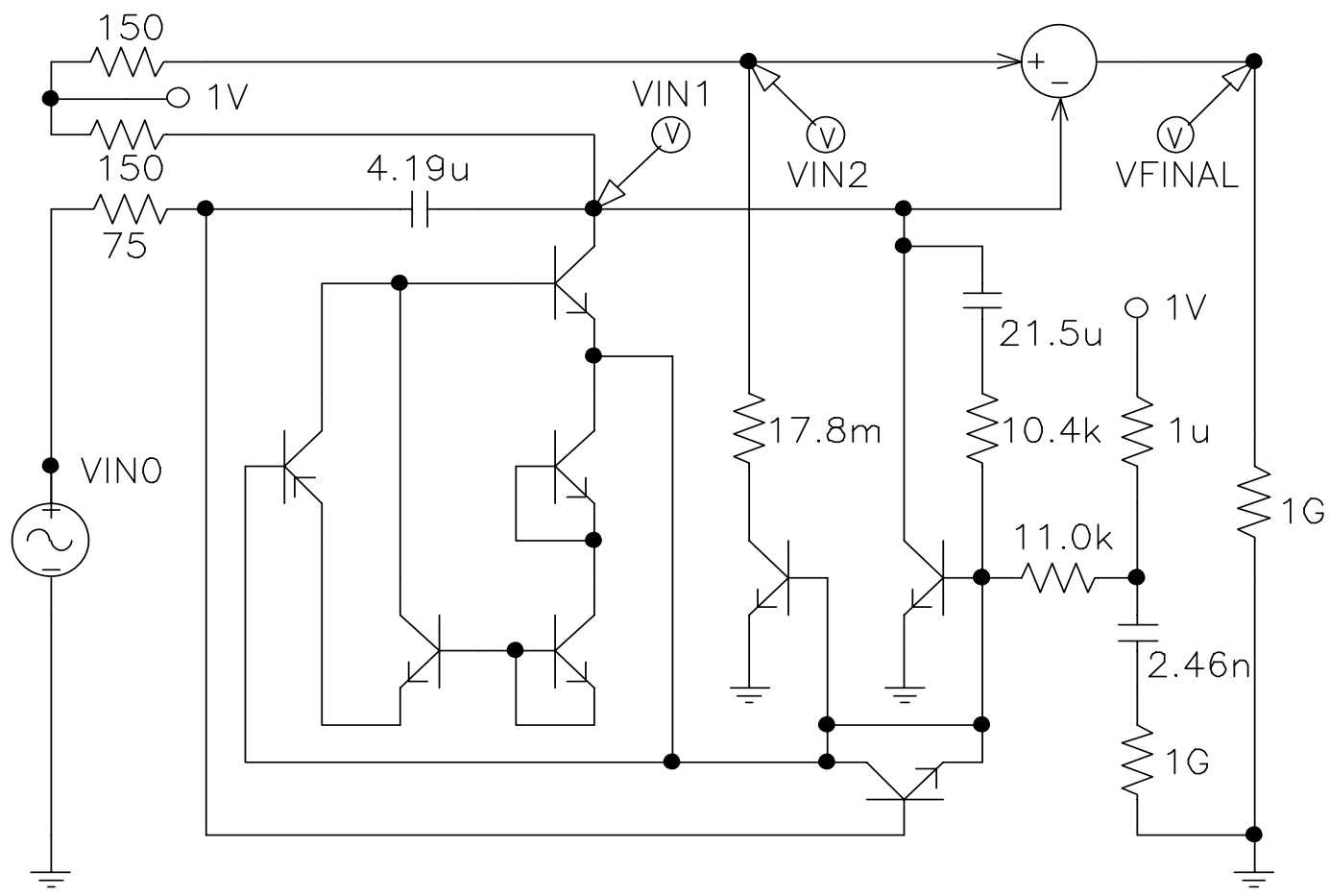




\section{POST-2000 PATENTED INVENTIONS}

\section{VOLTAGE-CURRENT-CONVERSION CIRCUIT}

BEST-OF-RUN FROM GENERATION 109

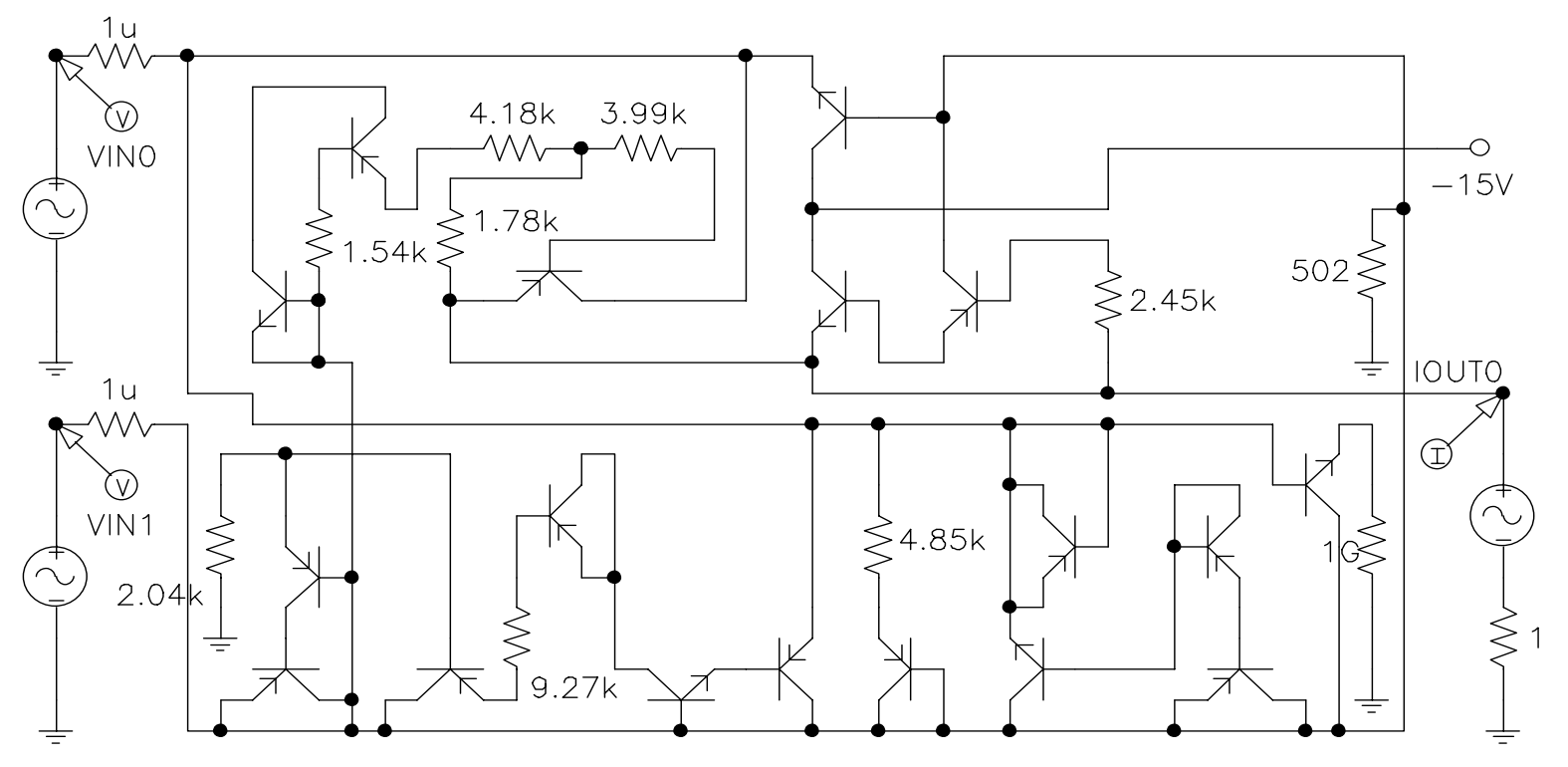




\section{POST-2000 PATENTED INVENTIONS}

\section{TUNABLE INTEGRATED ACTIVE FILTER - GENERATION 50}

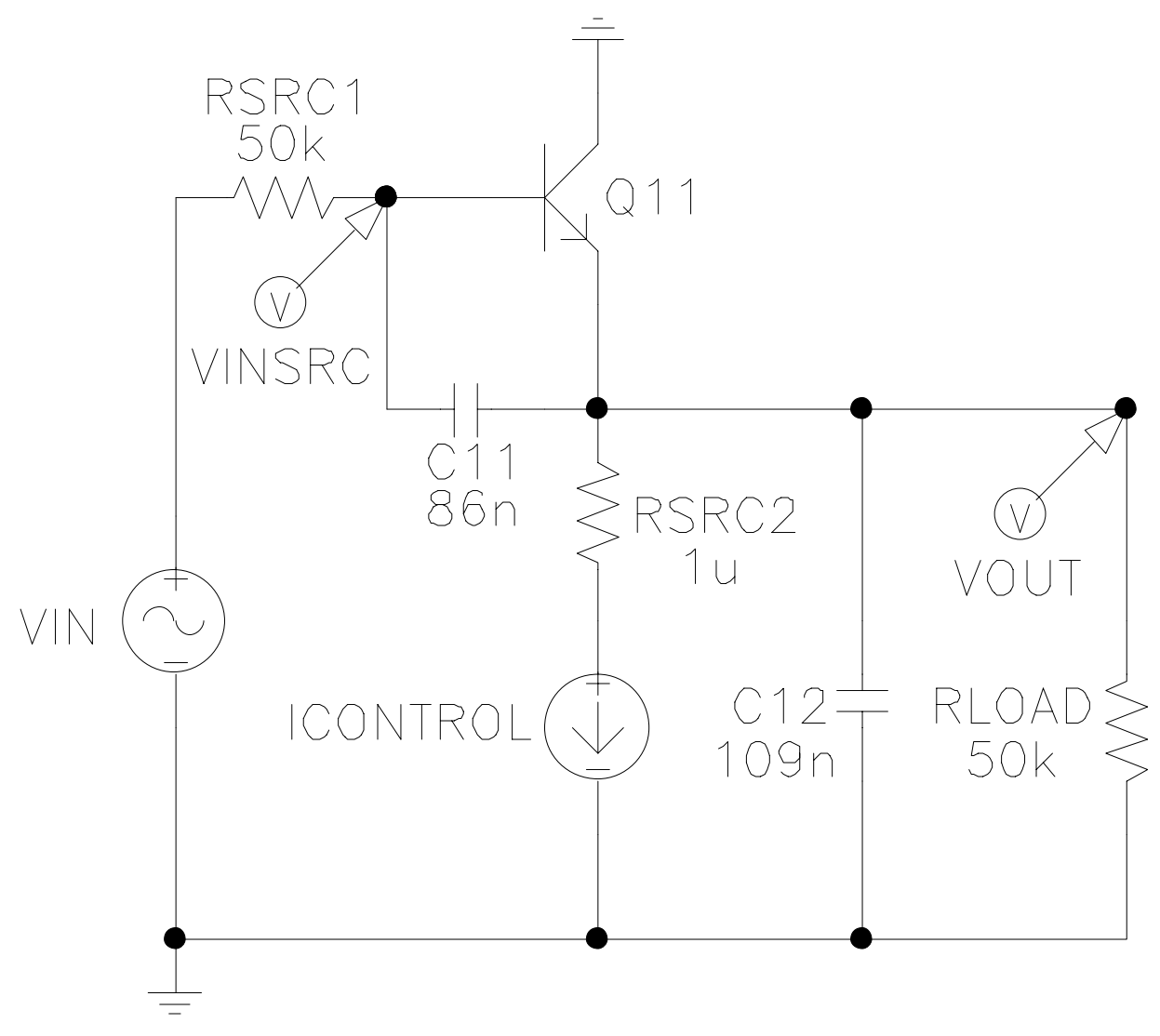


21 PREVIOUSLY PATENTED INVENTIONS REINVENTED BY GP

\begin{tabular}{|c|c|c|c|c|c|}
\hline & Invention & Date & Inventor & Place & Patent \\
\hline 1 & $\begin{array}{l}\text { Darlington } \\
\text { emitter- } \\
\text { follower } \\
\text { section } \\
\end{array}$ & 1953 & $\begin{array}{l}\text { Sidney } \\
\text { Darlington }\end{array}$ & $\begin{array}{l}\text { Bell Telephone } \\
\text { Laboratories }\end{array}$ & $2,663,806$ \\
\hline 2 & Ladder filter & 1917 & $\begin{array}{l}\text { George } \\
\text { Campbell }\end{array}$ & $\begin{array}{l}\text { American } \\
\text { Telephone and } \\
\text { Telegraph }\end{array}$ & $1,227,113$ \\
\hline 3 & $\begin{array}{l}\text { Crossover } \\
\text { filter }\end{array}$ & 1925 & $\begin{array}{l}\text { Otto Julius } \\
\text { Zobel }\end{array}$ & $\begin{array}{l}\text { American } \\
\text { Telephone and } \\
\text { Telegraph }\end{array}$ & $1,538,964$ \\
\hline 4 & $\begin{array}{l}\text { "M-derived } \\
\text { half section" } \\
\text { filter }\end{array}$ & 1925 & $\begin{array}{l}\text { Otto Julius } \\
\text { Zobel }\end{array}$ & $\begin{array}{l}\text { American } \\
\text { Telephone and } \\
\text { Telegraph }\end{array}$ & $1,538,964$ \\
\hline 5 & $\begin{array}{l}\text { Cauer } \\
\text { (elliptic) } \\
\text { topology for } \\
\text { filters }\end{array}$ & $\begin{array}{l}1934- \\
1936\end{array}$ & $\begin{array}{l}\text { Wilhelm } \\
\text { Cauer }\end{array}$ & $\begin{array}{l}\text { University of } \\
\text { Gottingen }\end{array}$ & $\begin{array}{l}1,958,742, \\
1,989,545\end{array}$ \\
\hline 6 & $\begin{array}{l}\text { Sorting } \\
\text { network }\end{array}$ & 1962 & $\begin{array}{l}\text { Daniel G. } \\
\text { O'Connor } \\
\text { and } \\
\text { Raymond J. } \\
\text { Nelson }\end{array}$ & $\begin{array}{l}\text { General Precision, } \\
\text { Inc. }\end{array}$ & $3,029,413$ \\
\hline 7 & $\begin{array}{l}\text { Computation } \\
\text { al circuits }\end{array}$ & $\begin{array}{l}\text { See } \\
\text { text }\end{array}$ & See text & See text & See text \\
\hline 8 & $\begin{array}{l}\begin{array}{l}\text { Electronic } \\
\text { thermometer }\end{array} \\
\end{array}$ & $\begin{array}{l}\text { See } \\
\text { text }\end{array}$ & See text & See text & See text \\
\hline 9 & $\begin{array}{l}\text { Voltage } \\
\text { reference } \\
\text { circuit }\end{array}$ & $\begin{array}{l}\text { See } \\
\text { text }\end{array}$ & See text & See text & See text \\
\hline 10 & $\begin{array}{l}60 \mathrm{~dB} \text { and } 96 \\
\mathrm{~dB} \text { amplifiers }\end{array}$ & $\begin{array}{l}\text { See } \\
\text { text }\end{array}$ & See text & See text & See text \\
\hline 11 & $\begin{array}{l}\text { Second- } \\
\text { derivative } \\
\text { controller }\end{array}$ & 1942 & Harry Jones & $\begin{array}{l}\text { Brown Instrument } \\
\text { Company }\end{array}$ & $2,282,726$ \\
\hline 12 & $\begin{array}{l}\text { Philbrick } \\
\text { circuit }\end{array}$ & 1956 & $\begin{array}{l}\text { George } \\
\text { Philbrick }\end{array}$ & $\begin{array}{l}\text { George A. } \\
\text { Philbrick } \\
\text { Researches }\end{array}$ & $2,730,679$ \\
\hline 13 & NAND circuit & 1971 & $\begin{array}{l}\text { David H. } \\
\text { Chung and } \\
\text { Bill H. }\end{array}$ & $\begin{array}{l}\text { Texas Instruments } \\
\text { Incorporated }\end{array}$ & $3,560,760$ \\
\hline
\end{tabular}




\begin{tabular}{|c|c|c|c|c|c|}
\hline & & & Terrell & & \\
\hline 14 & $\begin{array}{l}\text { PID } \\
\text { (proportional } \\
\text {, integrative, } \\
\text { and } \\
\text { derivative) } \\
\text { controller }\end{array}$ & 1939 & $\begin{array}{l}\text { Albert } \\
\text { Callender } \\
\text { and Allan } \\
\text { Stevenson }\end{array}$ & $\begin{array}{l}\text { Imperial Chemical } \\
\text { Limited }\end{array}$ & $2,175,985$ \\
\hline 15 & $\begin{array}{l}\text { Negative } \\
\text { feedback }\end{array}$ & 1937 & $\begin{array}{l}\text { Harold S. } \\
\text { Black }\end{array}$ & $\begin{array}{l}\text { American } \\
\text { Telephone and } \\
\text { Telegraph }\end{array}$ & $\begin{array}{l}2,102,670 \\
2,102,671\end{array}$ \\
\hline 16 & $\begin{array}{l}\text { Low-voltage } \\
\text { balun circuit }\end{array}$ & 2001 & $\begin{array}{l}\text { Sang Gug } \\
\text { Lee }\end{array}$ & $\begin{array}{l}\text { Information and } \\
\text { Communications } \\
\text { University }\end{array}$ & $6,265,908$ \\
\hline 17 & $\begin{array}{l}\text { Mixed } \\
\text { analog-digital } \\
\text { variable } \\
\text { capacitor } \\
\text { circuit } \\
\end{array}$ & 2000 & $\begin{array}{l}\text { Turgut } \\
\text { Sefket Aytur }\end{array}$ & $\begin{array}{l}\text { Lucent } \\
\text { Technologies Inc. }\end{array}$ & $6,013,958$ \\
\hline 18 & $\begin{array}{l}\text { High-current } \\
\text { load circuit }\end{array}$ & 2001 & $\begin{array}{l}\text { Timothy } \\
\text { Daun- } \\
\text { Lindberg } \\
\text { and Michael } \\
\text { Miller } \\
\end{array}$ & $\begin{array}{l}\text { International } \\
\text { Business Machines } \\
\text { Corporation }\end{array}$ & $6,211,726$ \\
\hline 19 & $\begin{array}{l}\text { Voltage- } \\
\text { current } \\
\text { conversion } \\
\text { circuit } \\
\end{array}$ & 2000 & $\begin{array}{l}\text { Akira } \\
\text { Ikeuchi and } \\
\text { Naoshi } \\
\text { Tokuda } \\
\end{array}$ & $\begin{array}{l}\text { Mitsumi Electric } \\
\text { Co., Ltd. }\end{array}$ & $6,166,529$ \\
\hline 20 & $\begin{array}{l}\text { Cubic } \\
\text { function } \\
\text { generator }\end{array}$ & 2000 & $\begin{array}{l}\text { Stefano } \\
\text { Cipriani and } \\
\text { Anthony A. } \\
\text { Takeshian } \\
\end{array}$ & $\begin{array}{l}\text { Conexant Systems, } \\
\text { Inc. }\end{array}$ & $6,160,427$ \\
\hline 21 & $\begin{array}{l}\text { Tunable } \\
\text { integrated } \\
\text { active filter }\end{array}$ & 2001 & $\begin{array}{l}\text { Robert } \\
\text { Irvine and } \\
\text { Bernd Kolb }\end{array}$ & $\begin{array}{l}\text { Infineon } \\
\text { Technologies AG }\end{array}$ & $6,225,859$ \\
\hline
\end{tabular}

\begin{tabular}{|l|l|l|l|}
\hline & Claimed invention & $\begin{array}{l}\text { Date of patent } \\
\text { application }\end{array}$ & Inventors \\
\hline 1 & $\begin{array}{l}\text { Improved general- } \\
\text { purpose tuning rules } \\
\text { for a PID controller }\end{array}$ & July 12, 2002 & $\begin{array}{l}\text { Martin A. Keane, John R. Koza, } \\
\text { and Matthew J. Streeter }\end{array}$ \\
\hline 2 & $\begin{array}{l}\text { Improved general- } \\
\text { purpose non-PID }\end{array}$ & July 12, 2002 & $\begin{array}{l}\text { Martin A. Keane, John R. Koza, } \\
\text { and Matthew J. Streeter }\end{array}$ \\
\hline
\end{tabular}


\begin{tabular}{|l|l|l|l|}
\hline & controllers & & \\
\hline
\end{tabular} 


\section{NOVELTY-DRIVEN EVOLUTION \\ EXAMPLE OF LOWPASS FILTER}

- Two factors in fitness measure

- Circuit's behavior in the frequency domain

- Largest number of nodes and edges (circuit components) of a subgraph of the given circuit that is isomorphic to a subgraph of a template representing the prior art. Graph isomorphism algorithm with the cost function being based on the number of shared nodes and edges (instead of just the number of nodes).
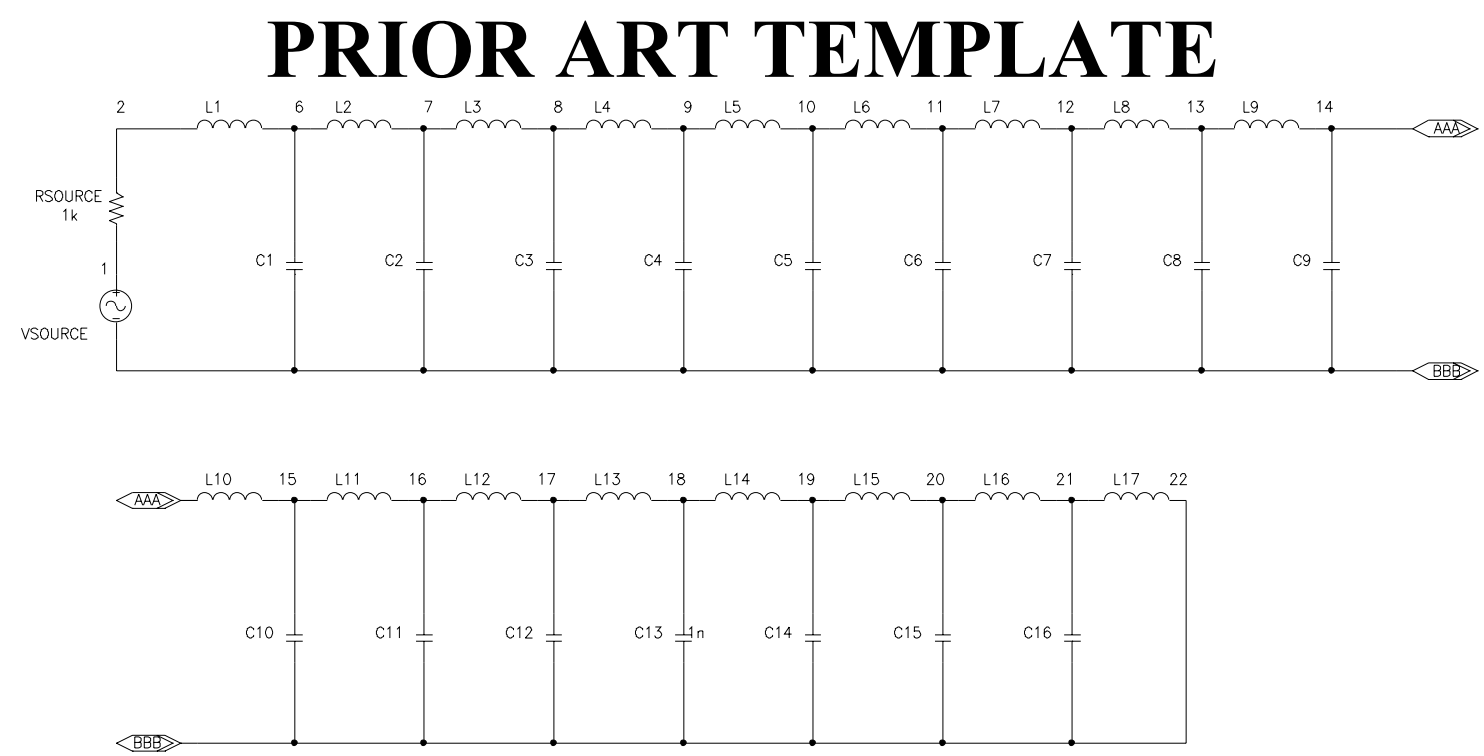


\section{NOVELTY-DRIVEN EVOLUTION - CONTINUED}

- For circuits not scoring the maximum number (101) of hits, the fitness of a circuit is the product of the two factors.

- For circuits scoring 101 hits (100\%-compliant individuals), fitness is the number of shared nodes and edges divided by 10,000 .

\section{FITNESS OF EIGHT 100\%-COMPLIANT CIRCUITS}

\begin{tabular}{|l|l|l|l|}
\hline Solution & $\begin{array}{l}\text { Frequency } \\
\text { factor }\end{array}$ & $\begin{array}{l}\text { Isomorphism } \\
\text { factor }\end{array}$ & Fitness \\
\hline 1 & 0.051039 & 7 & 0.357273 \\
\hline 2 & 0.117093 & 7 & 0.819651 \\
\hline 3 & 0.103064 & 7 & 0.721448 \\
\hline 4 & 0.161101 & 7 & 1.127707 \\
\hline 5 & 0.044382 & 13 & 0.044382 \\
\hline 6 & 0.133877 & 7 & 0.937139 \\
\hline 7 & 0.059993 & 5 & 0.299965 \\
\hline 8 & 0.062345 & 11 & 0.685795 \\
\hline
\end{tabular}




\section{LAYOUT - LOWPASS FILTER $100 \%$-COMPLIANT CIRCUITS}

GENERATION 25 WITH 5 CAPACITORS AND 11 INDUCTORS - AREA OF 1775.2

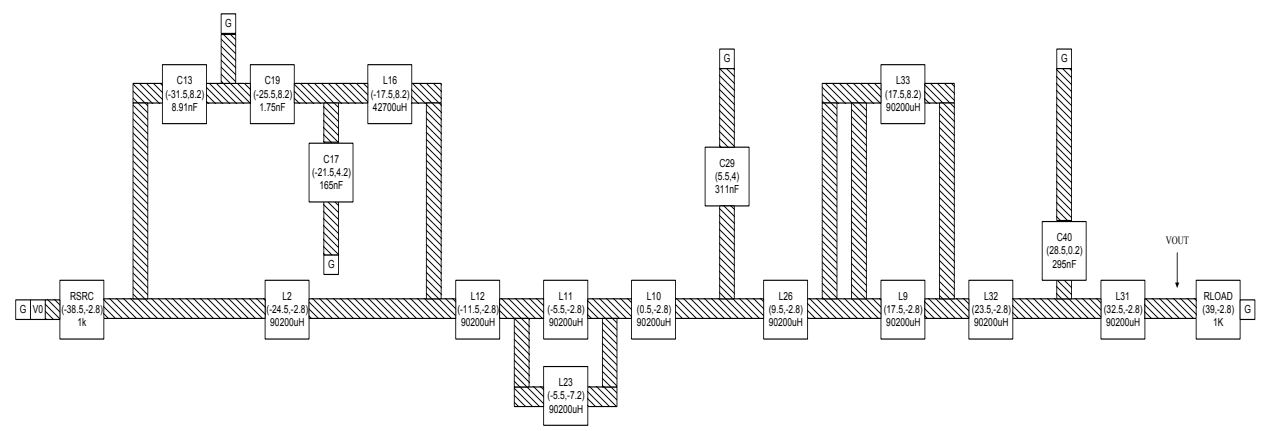

GENERATION 30 WITH 10 INDUCTORS AND 5 CAPACITORS - AREA OF 950.3

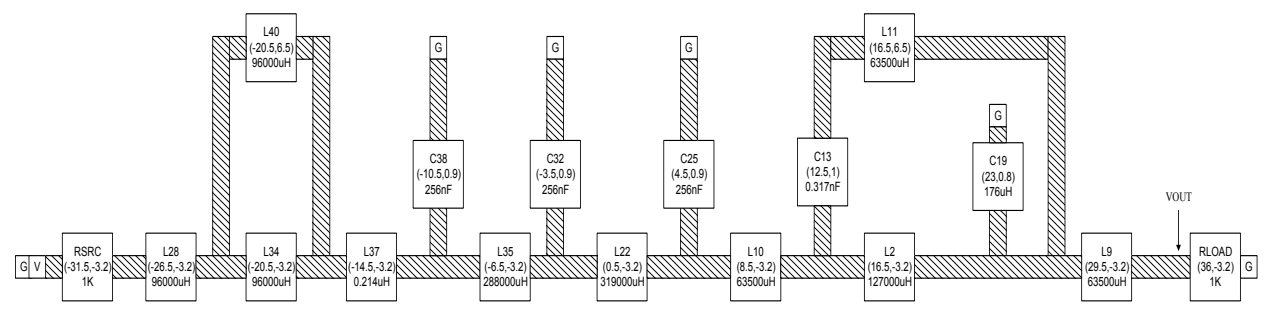

\section{BEST-OF-RUN CIRCUIT OF}

GENERATION 138 WITH 4 INDUCTORS

AND 4 CAPACITORS - AREA OF 359.4

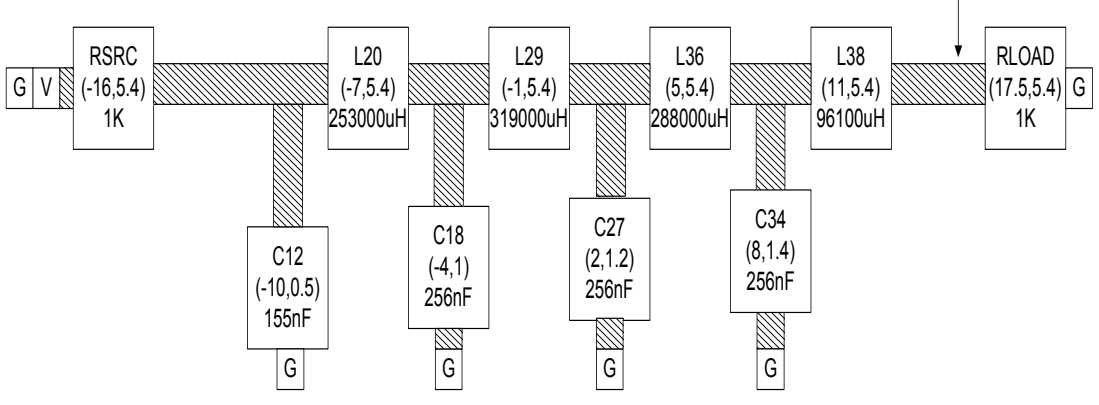




\section{LAYOUT — 60 DB AMPLIFIER (USING TRANSISTORS)}

COMPARISON

\begin{tabular}{|l|l|l|l|l|}
\hline Gen & $\begin{array}{l}\text { Component } \\
\text { s }\end{array}$ & Area & $\begin{array}{l}\text { Four } \\
\text { penalties }\end{array}$ & Fitness \\
\hline 65 & 27 & 8,234 & 33.034348 & 33.042583 \\
\hline 101 & 19 & 4,751 & 0.061965 & 0.004751 \\
\hline
\end{tabular}

BEST-OF-RUN CIRCUIT FROM GENERATION 101

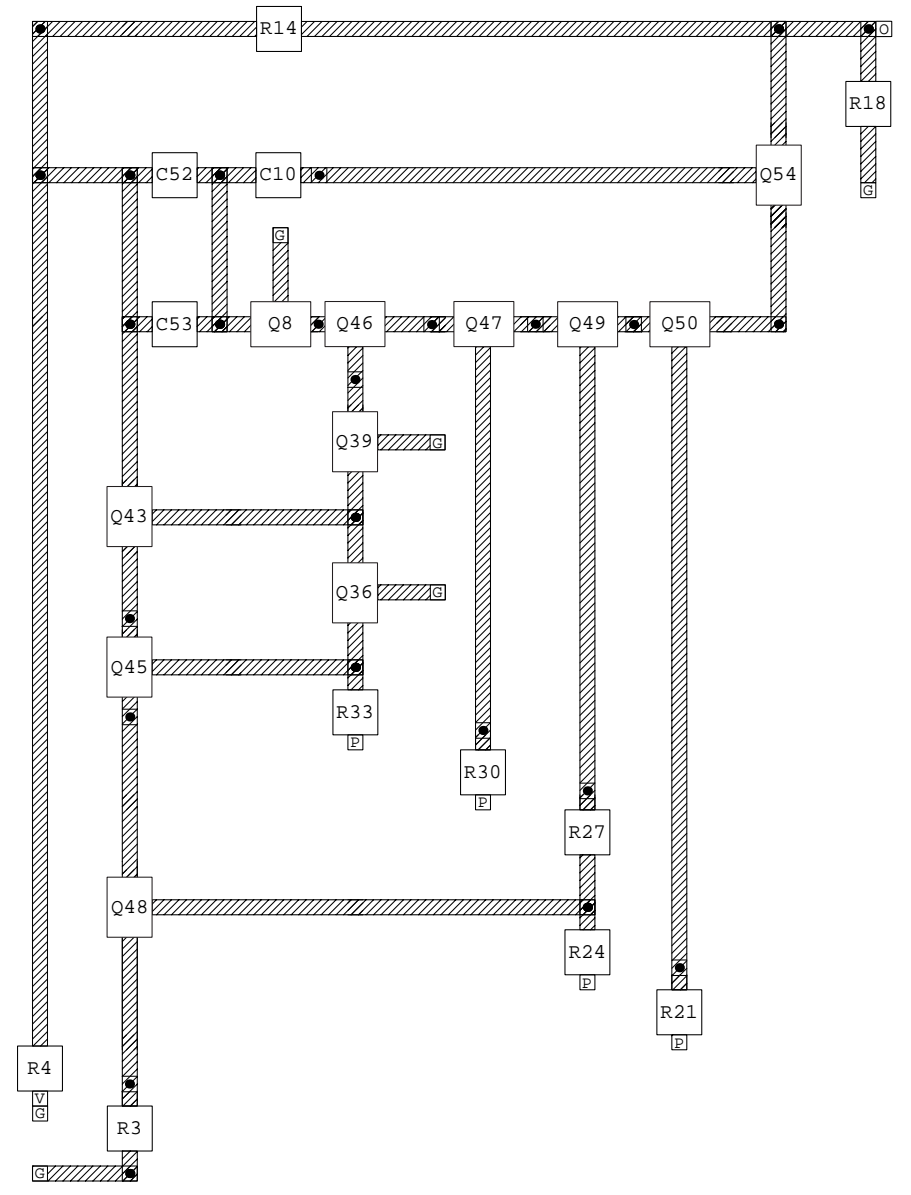




\section{PID CONTROLLER}

Block diagram of a plant and a PID controller composed of proportional (P), integrative (I), and derivative (D) blocks

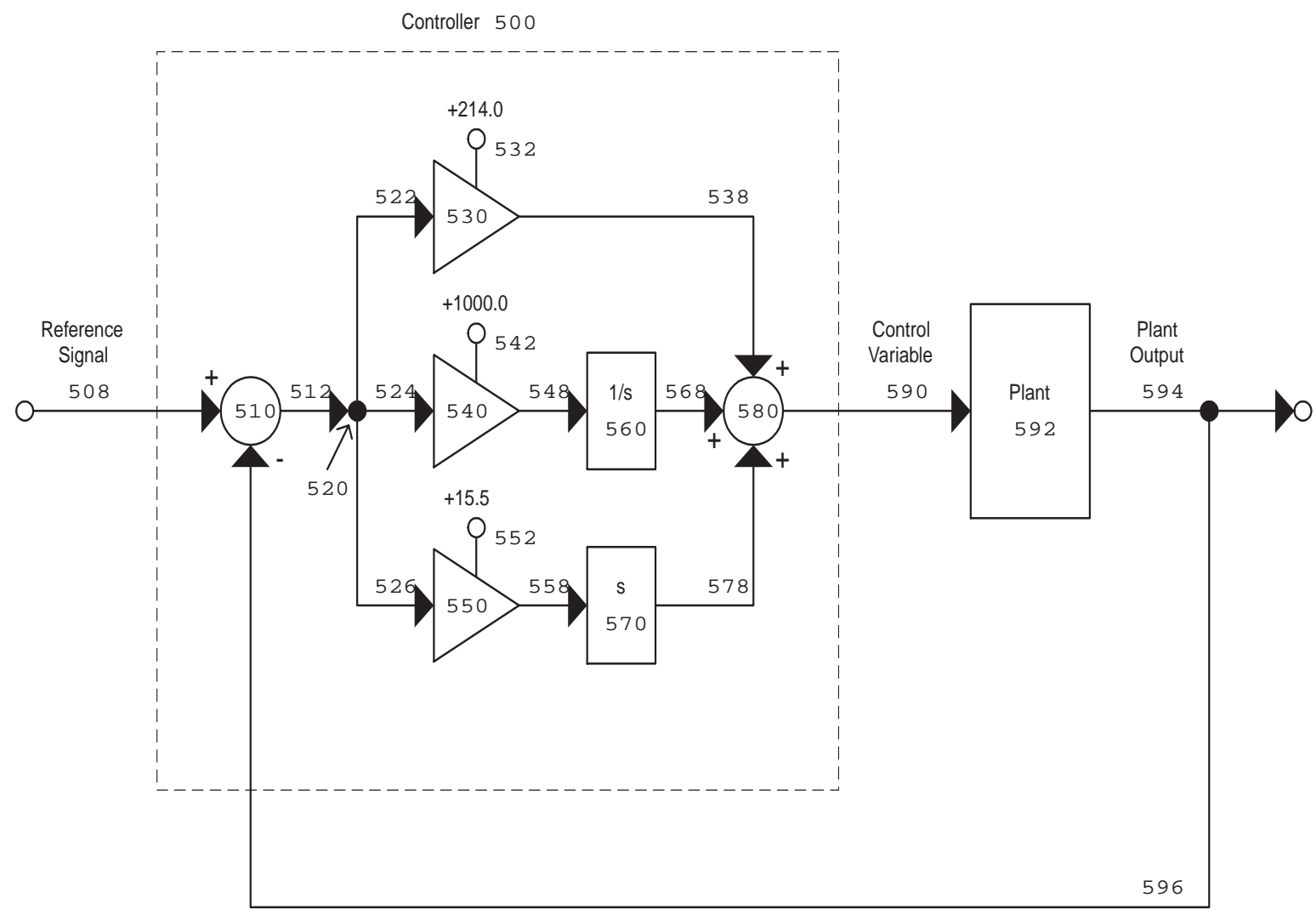




\section{PROGRAM TREE REPRESENTATION FOR PID CONTROLLER}

- ADF can be used for reuse.

- Automatically defined function ADFO takes the difference between the reference signal and the plant output and makes this difference available to three points in the resultproducing branch

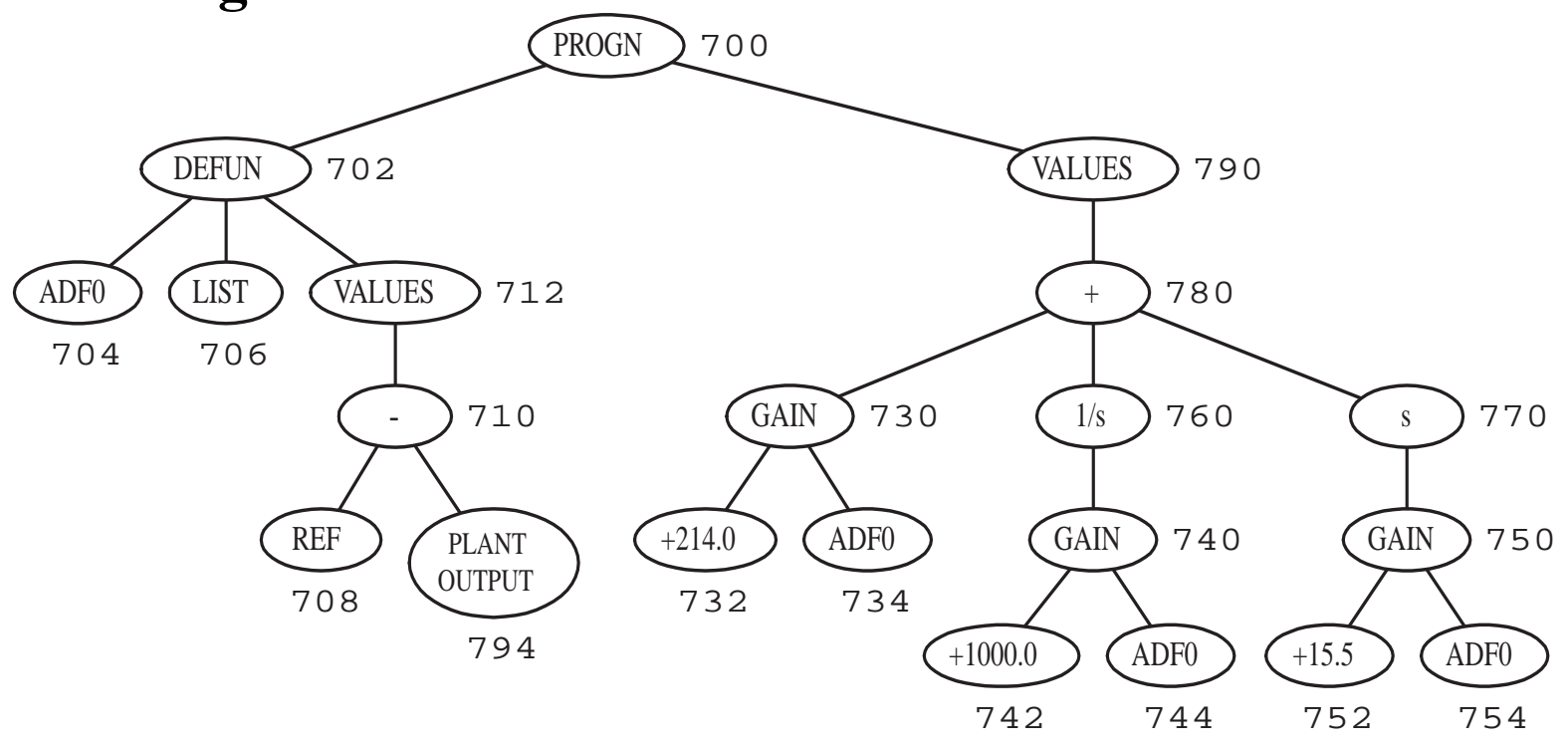

- ADF can be used for internal feedback

ADFO

Input

930

0

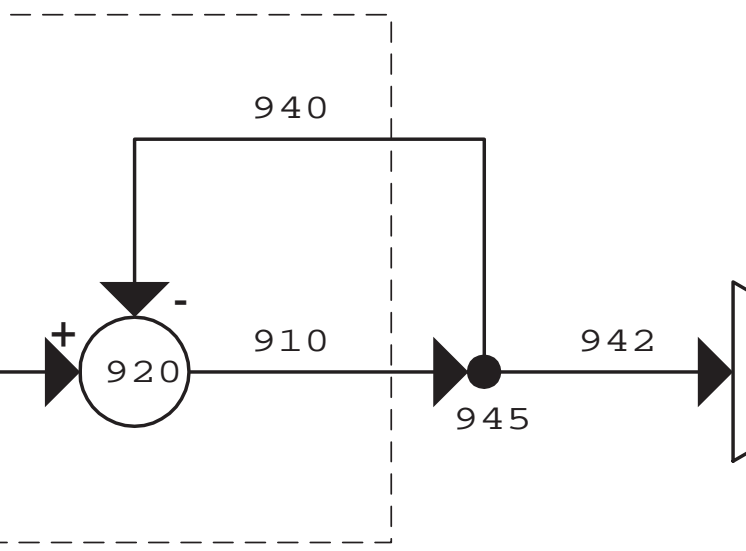

$+3.14$

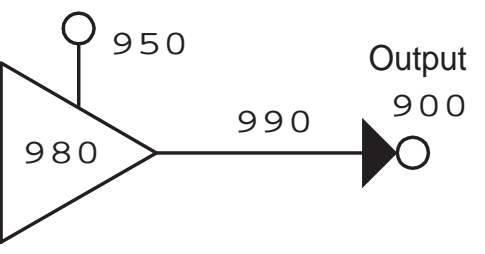




\section{FUNCTION SET AND TERMINAL SET FOR TWO-LAG PLANT PROBLEM}

- The function set, F (for every part of the result-producing branch and any automatically defined functions except the arithmetic-performing subtrees) is

$$
\begin{aligned}
F= & \text { \{GAIN, INVERTER, LEAD, IAG, LAG2, } \\
& \text { DIFFERENTIAL_INPUT_INTEGRATOR, } \\
& \text { DIFFERENTIATOR, ADD_SIGNAL, } \\
& \text { SUB_SIGNAL, ADD_3_SIGNAL, ADF0, } \\
& \text { ADF1, ADF2, ADF3, ADF 4 }
\end{aligned}
$$

- The terminal set, T, (for every part of the result-producing branch and any automatically defined functions except the arithmetic-performing subtrees) is

$$
\begin{aligned}
& T=\{\text { REFERENCE_SIGNAL, } \\
& \text { CONTROLIER_OUTPUT, PIANT_OUTPUT, } \\
& \text { CONSTANT_0\} }
\end{aligned}
$$




\section{ARITHMETIC-PERFORMING SUBTREES FOR THE TWO-LAG PLANT PROBLEM}

- Signal processing blocks such as GAIN, LEAD, LAG, and LAG2 possess numerical parameter(s)

- Parameter values can be established by an arithmeticperforming subtree

- A constrained syntactic structure enforces a different function and terminal set for the arithmetic-performing subtrees (as opposed to all other parts of the program tree).

- Terminal set, $T_{\text {aps }}$, for the arithmetic-performing subtrees $\mathbf{T}_{\text {aps }}=\{\mathfrak{R}\}$

where $\mathfrak{R}$ denotes constant numerical terminals in the range from -1.0 to +1.0

- Function set, $F_{\text {aps }}$, for the arithmetic-performing subtrees $F_{\text {aps }}=\{$ ADD_NUMERIC, SUB_NUMERIC $\}$ 


\section{FITNESS MEASURE FOR TWO-LAG PLANT}

- 10-element fitness measure

- The first eight elements of the fitness measure represent the eight choices of a particular one of two different values of the plant's internal gain, $K(1.0$ and 2.0$)$, in conjunction with a particular one of two different values of the plant's time constant $\tau(0.5$ and 1.0$)$, in conjunction with a particular one of two different values for the height of the reference signal. The two reference signals are step functions that rise from 0 to 1 volts (or 1 microvolts) at $t=$ 100 milliseconds.

- For each of these eight fitness cases, a transient analysis is performed in the time domain using the SPICE simulator. The contribution to fitness for each of these eight elements is

$$
\int_{t=0}^{9.6} t|e(t)| A(e(t)) B d t
$$

- $e(t)$ is difference between plant output and reference signal.

- Multiplication by $B\left(1^{6}\right.$. or 1$)$ makes both reference signals equally influential.

- Additional weighting function, $A$, heavily penalizes noncompliant amounts of overshoot. $A$ weights all variations up to $2 \%$ above the reference signal by 1.0 , but others by 10.0 .

- The $9^{\text {th }}$ element of the fitness measure exposes the controller to an extreme spiked reference signal.

- The $10^{\text {th }}$ element constrains the frequency of the control variable so as to avoid extreme high frequencies. 


\section{BEST-OF-RUN GENETICALLY EVOLVED CONTROLLER FROM GENERATION 32 FOR THE TWO-LAG PLANT}

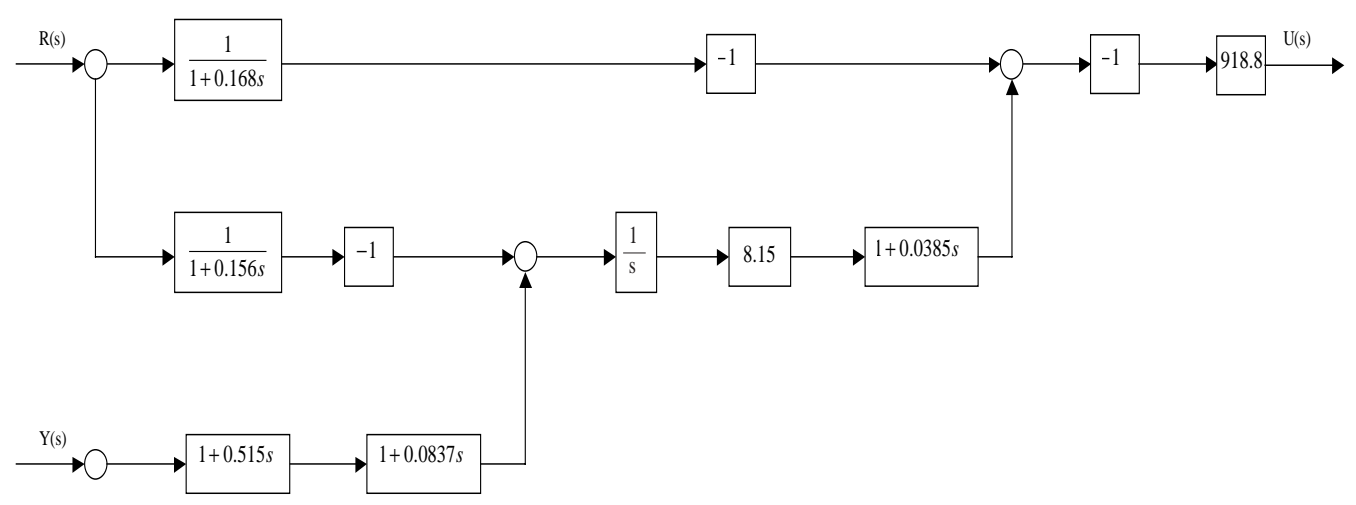




\section{COMPARISON OF THE TIME-DOMAIN RESPONSE TO 1-VOLT STEP INPUT FOR THE EVOLVED CONTROLLER (TRIANGLES) AND THE BISHOP AND DORF CONTROLLER (SQUARES) FOR THE TWO-LAG PLANT WITH $K=1$ AND $\tau=1$}

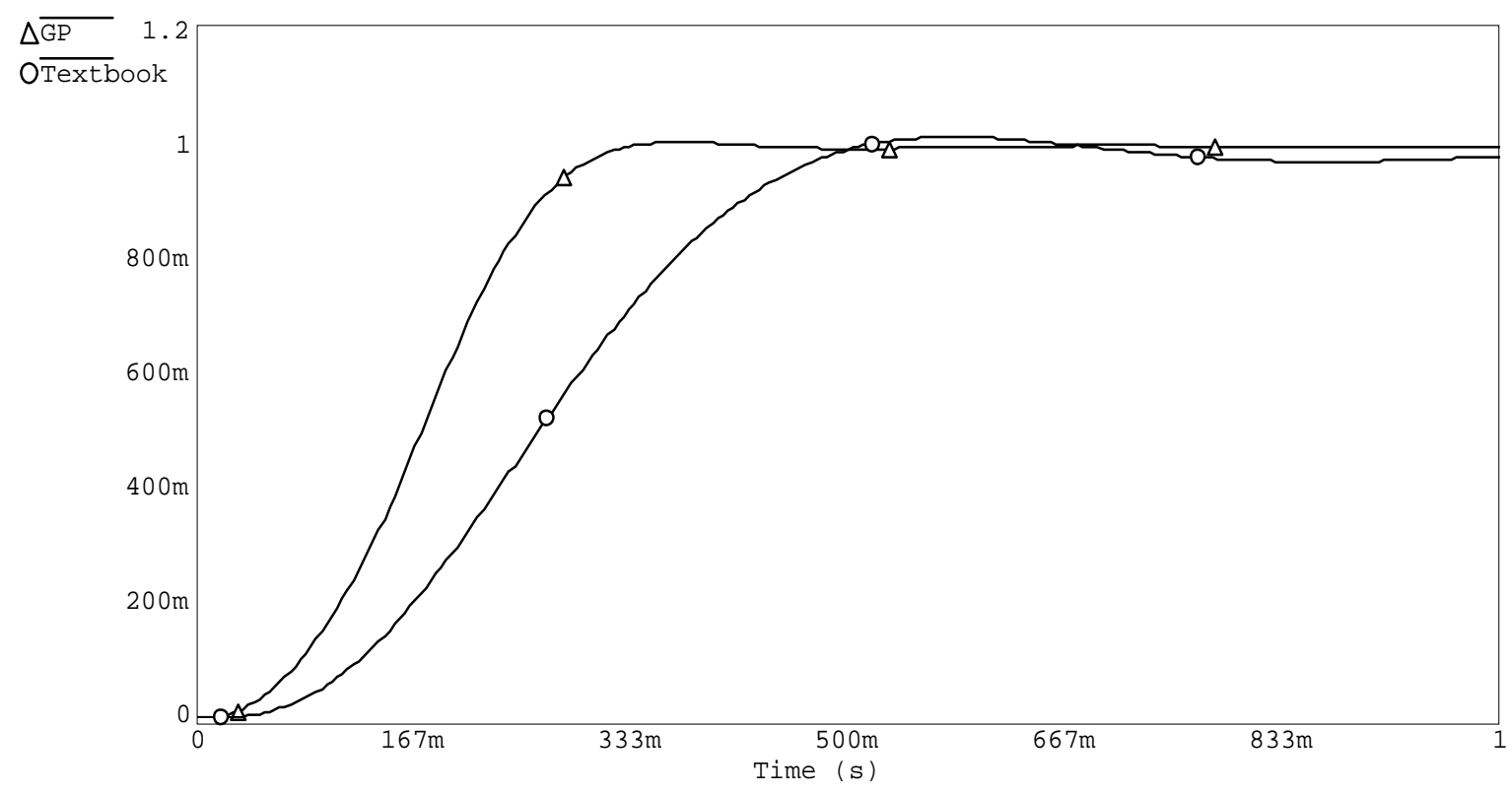

OVERALL MODEL

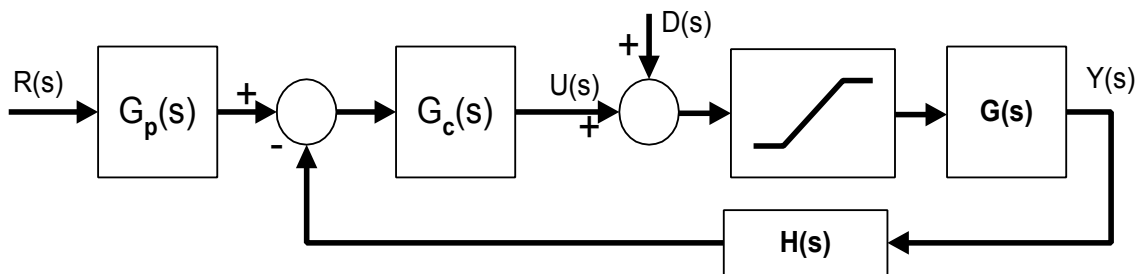




\section{COMPARISON OF THE TIME-DOMAIN} RESPONSE TO A 1-VOLT DISTURBANCE SIGNAL OF THE EVOLVED CONTROLLER(TRIANGLES) AND THE BISHOP AND DORF CONTROLLER (CIRCLES) FOR THE TWO-LAG PLANT WITH $K=1$ AND $\tau=1$

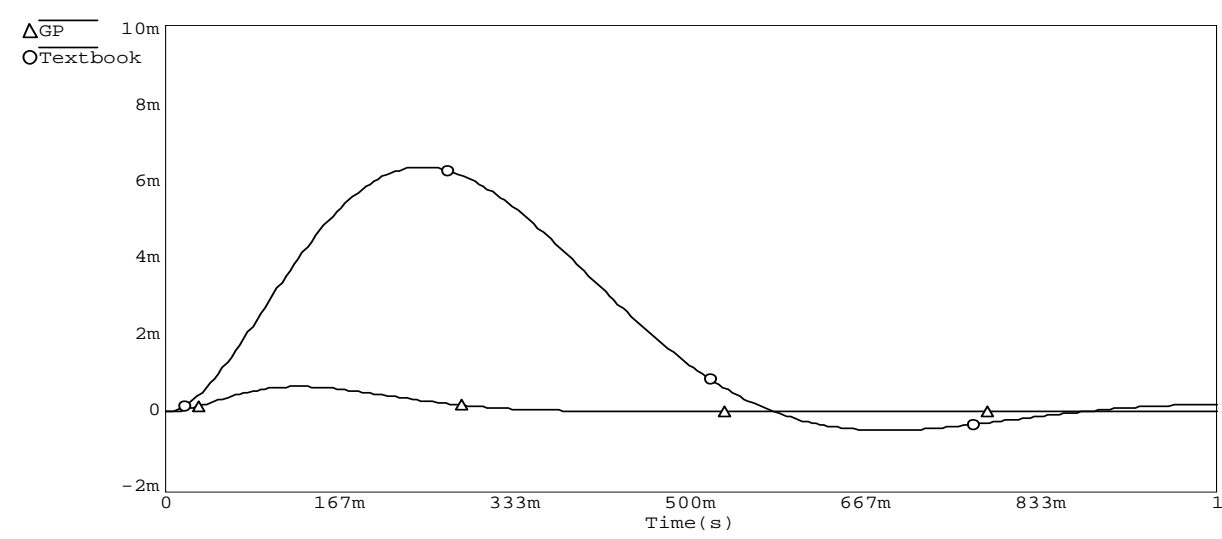




\section{REVERSE ENGINEERING OF METABOLIC PATHWAYS (4-REACTION NETWORK IN PHOSPHOLIPID CYCLE)}

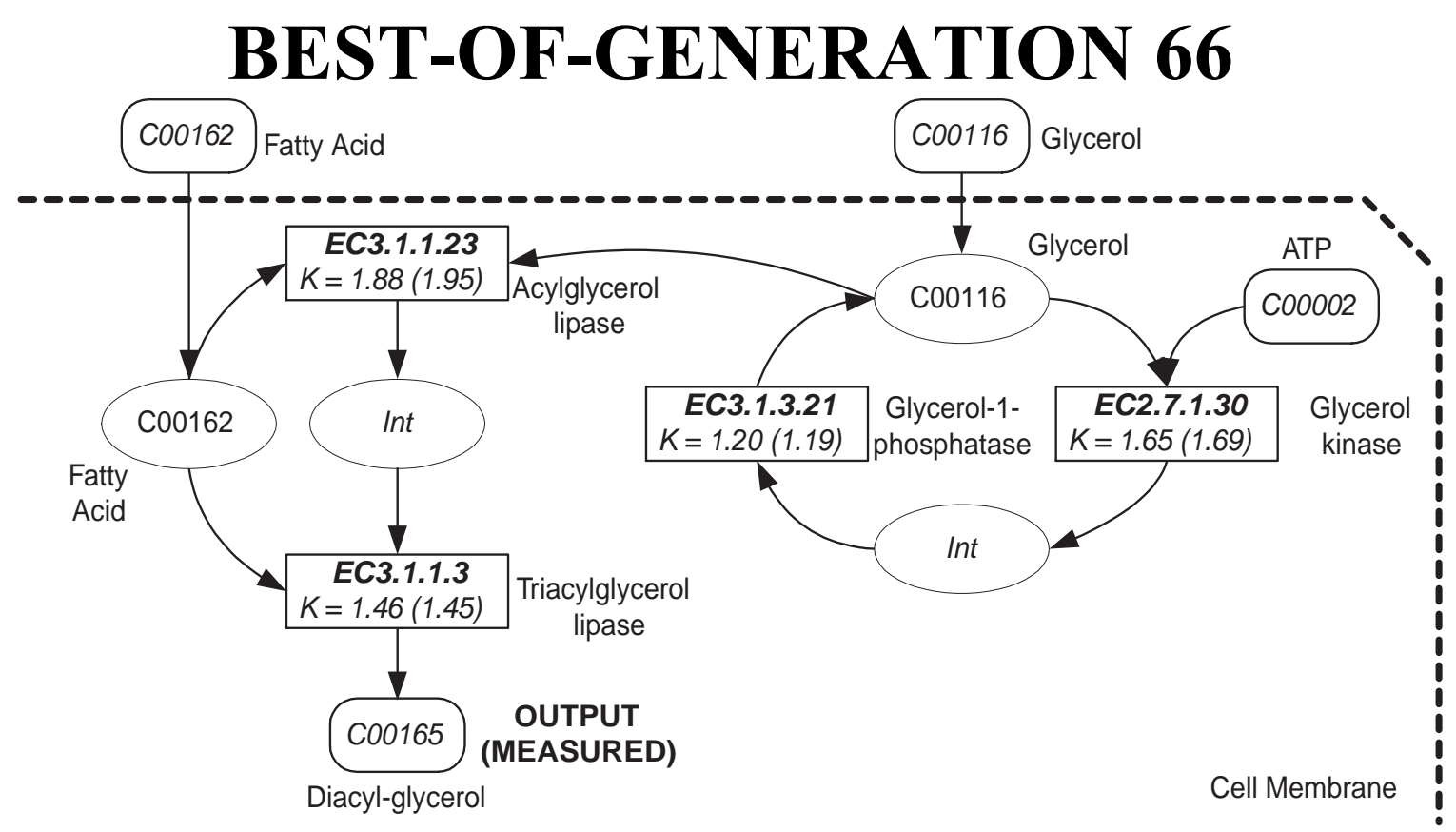

DESIRED

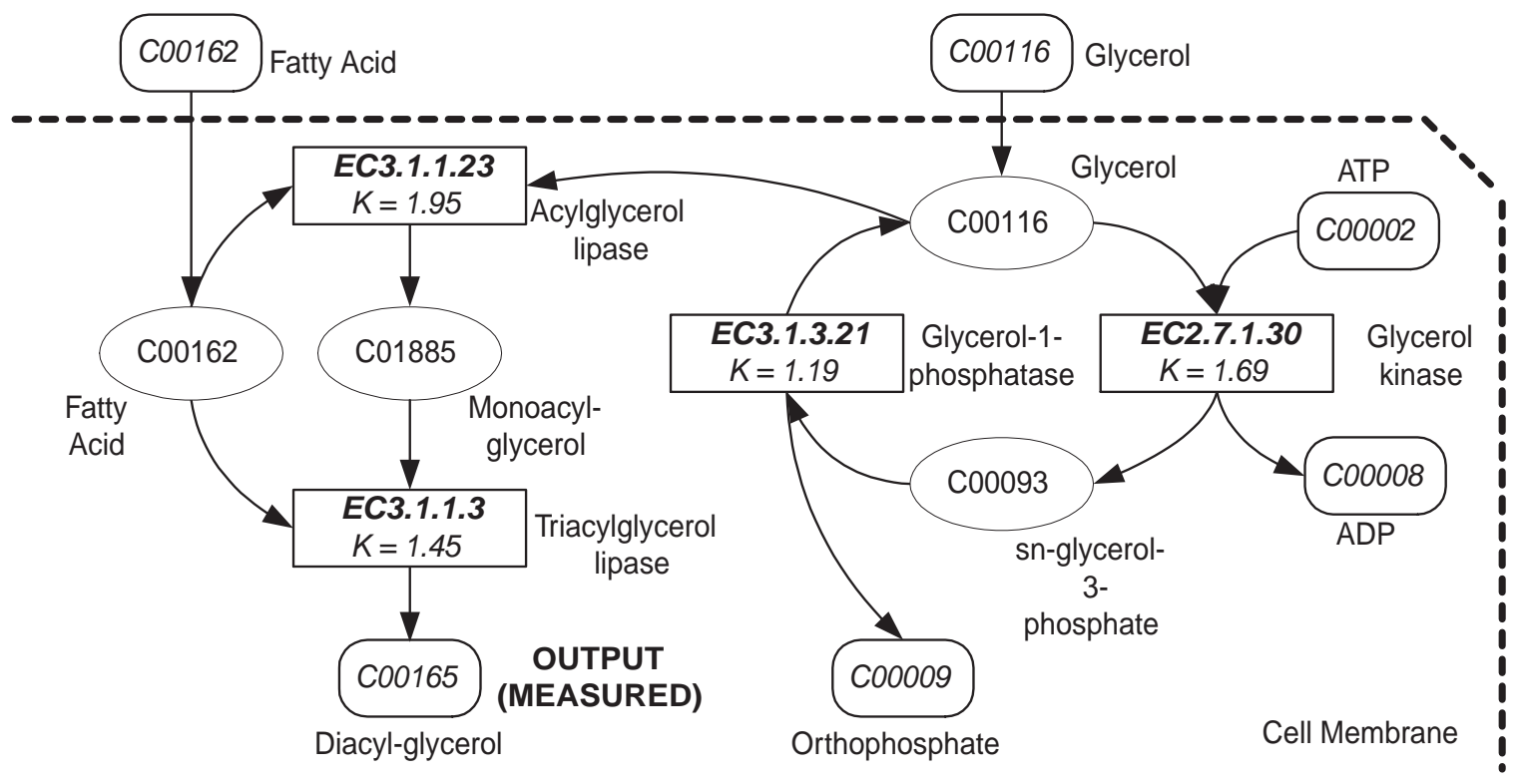




\section{CHARACTERISTICS SUGGESTING THE USE OF GENETIC PROGRAMMING}

(1) discovering the size and shape of the solution,

(2) reusing substructures,

(3) discovering the number of substructures,

(4) discovering the nature of the hierarchical references among substructures,

(5) passing parameters to a substructure,

(6) discovering the type of substructures (e.g., subroutines, iterations, loops, recursions, or storage),

(7) discovering the number of arguments possessed by a substructure,

(8) maintaining syntactic validity and locality by means of a developmental process, or

(9) discovering a general solution in the form of a parameterized topology containing free variables 


\section{MANY DIFFERENT GA/ES ENCODINGS HAVE BEEN SUCCESSFULLY USED}

A mixture of real-valued variables, integer-valued variables, and categorical variables are encoded in the chromosome

\begin{tabular}{|l|l|l|l|l|l|l|l|l|l|l|l|l|l|l|l|}
\hline $\mathbf{L}$ & .220 & 2 & 3 & $\mathbf{C}$ & 403. & 3 & 6 & $\mathbf{L}$ & .528 & 6 & 9 & $\mathbf{L}$ & .041 & 9 & 0 \\
\hline
\end{tabular}

- Bit-string chromosome

\begin{tabular}{|c|c|c|c|c|c|}
\hline Resistor & & & & & 5 \\
\hline \begin{tabular}{l|l}
0 & 1
\end{tabular} & 0 & 0 & 1 & 0 & 1 \\
\hline
\end{tabular}

- The component type (a categorical variable) is encoded as 2 bits $(01=$ resistor, etc. $)$

- The component value (real-valued number) is encoded as 8 bits

- The node (integer-valued variable) to which the component's $1^{\text {st }}$ lead is connected is encoded by 3 bits

- The node (integer-valued variable) to which the component's $2^{\text {nd }}$ lead is connected is encoded by 3 bits

- Note that the number of nodes is capped at 8 (or assumed to be 8) 


\section{IT IS OFTEN POSSIBLE TO USE THE GENETIC ALGORITHM (GA) OR EVOLUTION STRATEGIES EVEN WHEN THE SIZE AND SHAPE OF THE SOLUTION IS A MAJOR ISSUE}

- Variable-length genetic algorithm (VGA)

- Maintain constraints

Chromosome \#1

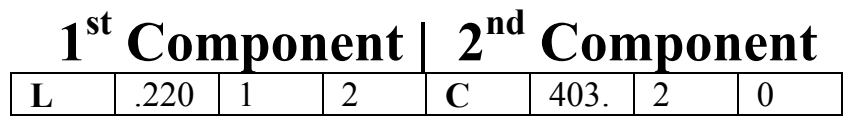

Chromosome \#2

$\mathbf{1}^{\text {st }}$ Component
\begin{tabular}{|l|l|l|l|l|l|l|}
\hline $\mathbf{R}$ & 250. & $\mathbf{2}^{\text {nd }}$ & \multicolumn{3}{|c|}{ Component } \\
\hline
\end{tabular}

Nominal Offspring \#1 is invalid $1^{\text {st }}$ Component $\mid 2^{\text {nd }}$ Component

\begin{tabular}{|l|l|l|l|l|l|l|l|}
\hline $\mathbf{L}$ & .220 & 1 & 2 & $\mathbf{C}$ & 100. & 1 & 2 \\
\hline
\end{tabular}

- Penalize (in fitness measure)

- Delete

- Repair (most common method)

- Inundate 


\section{STRONG INDICATIONS FOR USING GENETIC ALGORITHM (GA) OR EVOLUTION STRATEGIES (ES)}

- The size and shape of the solution is known or fixed

- Ascertaining numerical parameters is the major issue

- Simplicity is a major consideration

- On-chip evolution the algorithm's logic is implemented on the chip in hardware 


\section{AUTOMATIC SYNTHESIS OF A YAGI- UDA WIRE ANTENNA USING GENETIC ALGORITHM (LINDEN 1997)}

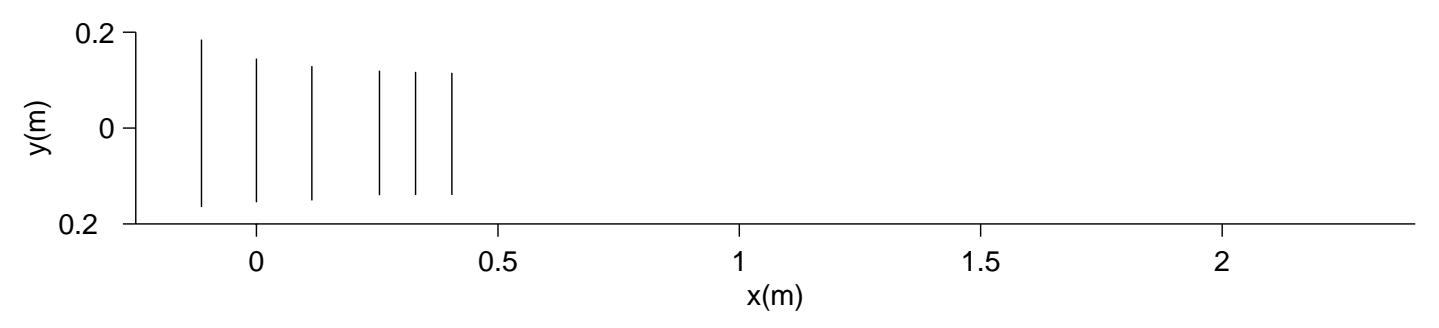

- When the genetic algorithm (GA) operating on fixedlength character strings was used to synthesize a particular Yagi-Uda wire antenna by Linden (1997), the chromosome was based on

- a particular number of reflectors (one) and -a particular number of directors.

The chromosome encoded

- the spacing between the parallel wires

- the length of each of the parallel wires 


\section{AUTOMATIC SYNTHESIS OF A YAGI- UDA WIRE ANTENNA USING GENETIC ALGORITHM (LINDEN 1997) - CONTINUED}

- When the genetic algorithm (GA) operating on fixedlength character strings was used to synthesize a Yagi-Uda wire antenna (Linden 1997), the following decisions were made by the human user prior to the start of the run:

(1) the number of reflectors (one),

(2) the number of directors,

(3) the fact that the driven element, the directors, and the reflector are all single straight wires,

(4) the fact that the driven element, the directors, and the reflector are all arranged in parallel,

(5) the fact that the energy source (via the transmission line) is connected only to single straight wire (the driven element) - that is, all the directors and reflectors are parasitically coupled

- Characteristics (3), (4), and (5) are essential characteristics of the Yagi-Uda antenna, namely an antenna with multiple parallel parasitically coupled straight-line directors, a single parallel parasitically coupled straight-line reflector, and a straight-line driven element. That it, the GA run assumed that the answer would be a Yagi-Uda antenna. 


\section{AUTOMATIC SYNTHESIS OF A WIRE ANTENNA}

\section{EXAMPLE OF TURTLE FUNCTIONS USED TO CREATE WIRE ANTENNA}

1 (PROGN3

2 (TURN-RIGHT 0.125 )

3 (LANDMARK

4

5

6

7

8

(REPEAT 2

(PROGN2

(DRAW 1.0 HALF-MM-WIRE)

(DRAW 0.5 NO-WIRE)))

(TRANSLATE-RIGHT 0.1250 .75$)$ )

$\triangle \quad \checkmark$

(a)

(b)

(c)

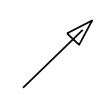

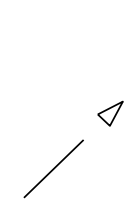

(d)

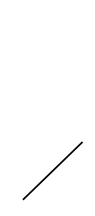

(e)

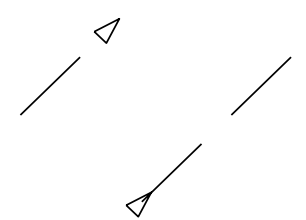

(f)

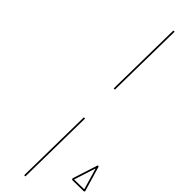

(g)

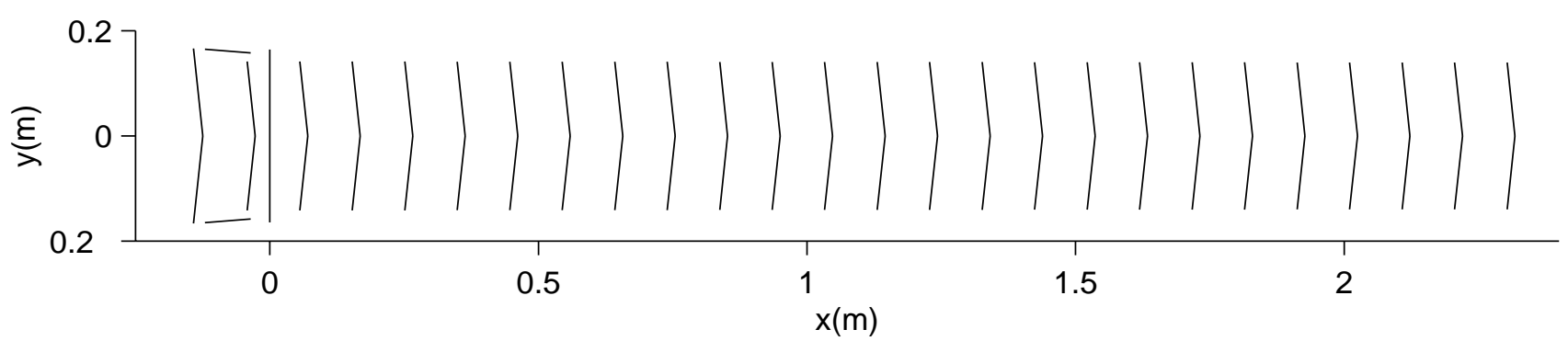




\section{BEST-OF-RUN ANTENNA FROM \\ GENERATION 90 \\ — FITNESS OF-16.04}

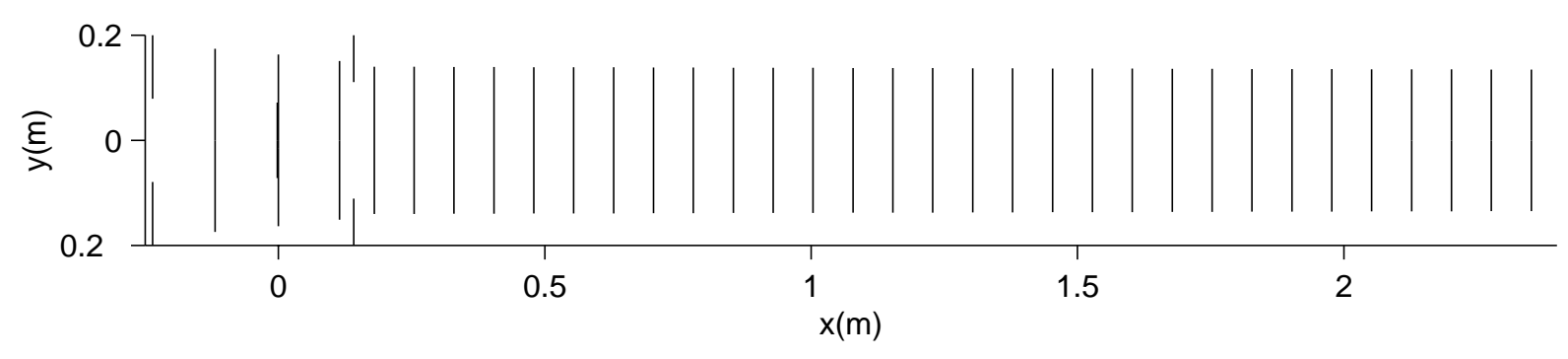

- The GP run discovered

(1) the number of reflectors (one),

(2) the number of directors,

(3) the fact that the driven element, the directors, and the reflector are all single straight wires,

(4) the fact that the driven element, the directors, and the reflector are all arranged in parallel,

(5) the fact that the energy source (via the transmission line) is connected only to single straight wire (the driven element) - that is, all the directors and reflectors are parasitically coupled

- Characteristics (3), (4), and (5) are essential characteristics of the Yagi-Uda antenna, namely an antenna with multiple parallel parasitically coupled straight-line directors, a single parallel parasitically coupled straight-line reflector, and a straight-line driven element. 


\section{REUSE LOWPASS FILTER USING ADFS}

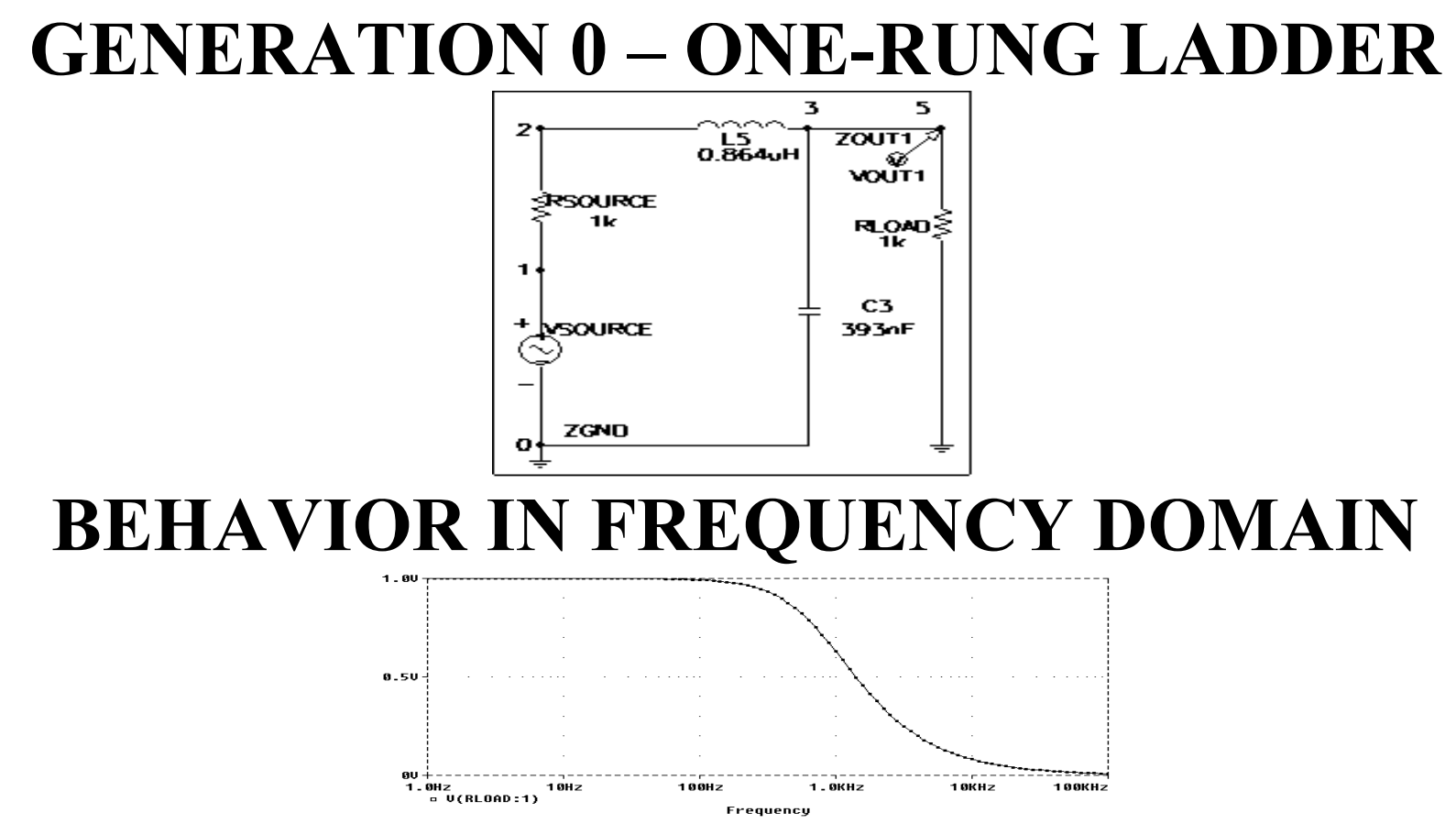




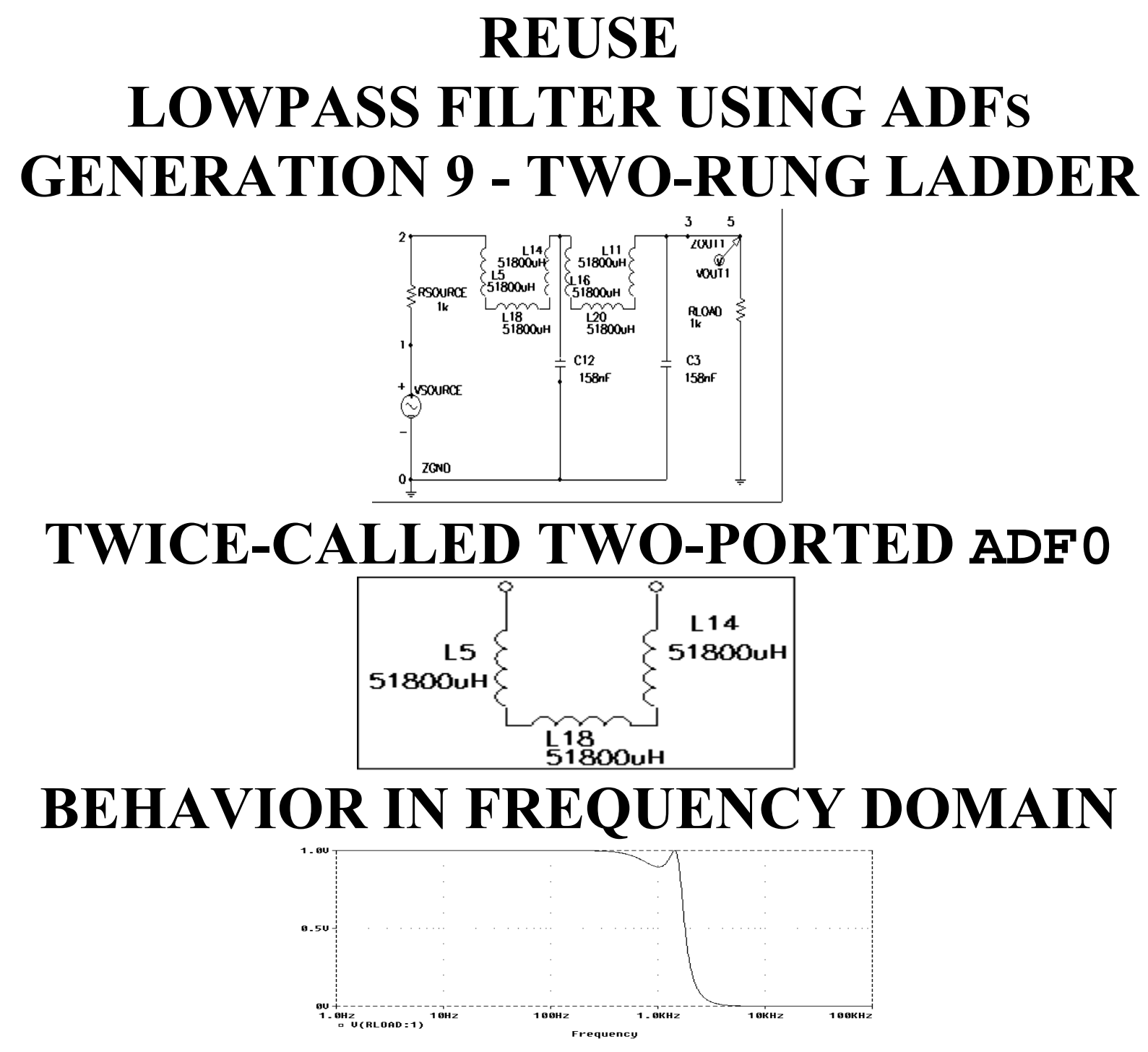



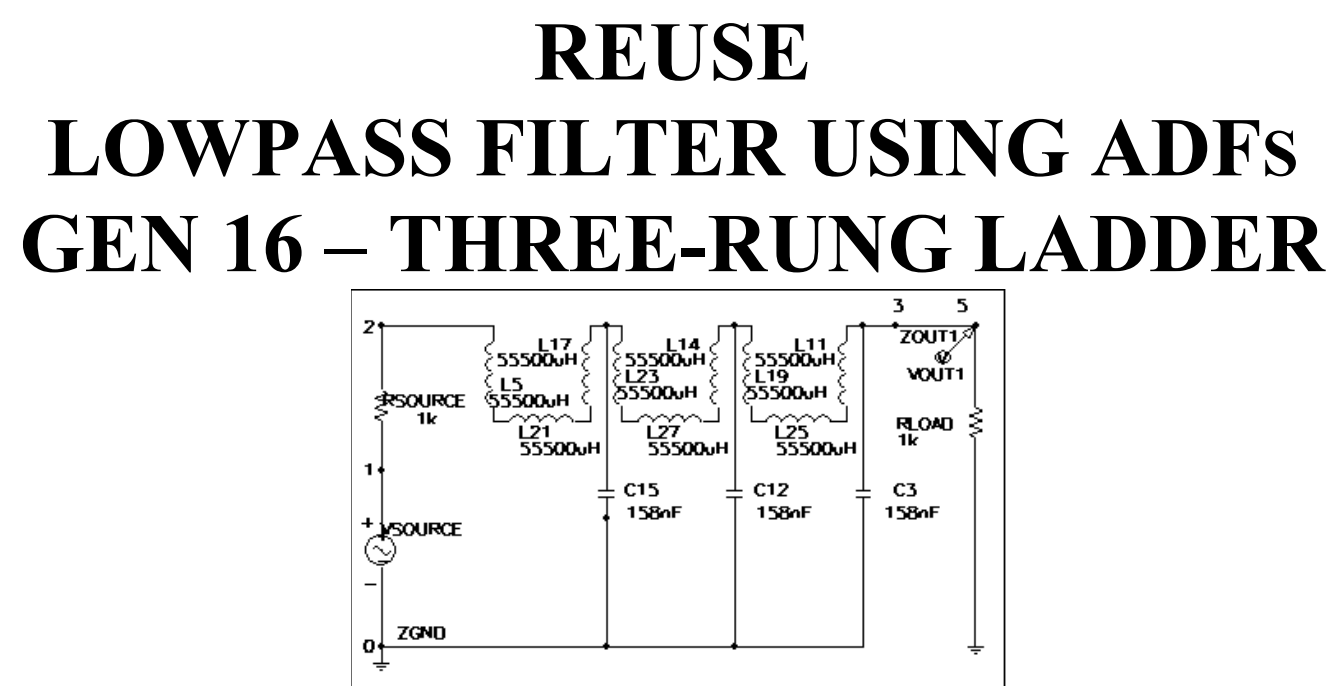

THRICE-CALLED TWO-PORTED ADFO

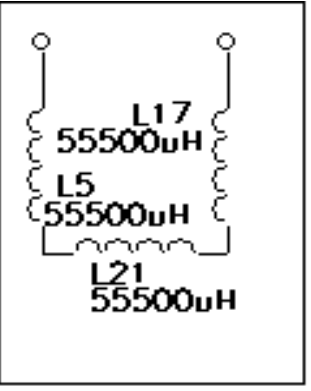

BEHAVIOR IN FREQUENCY DOMAIN

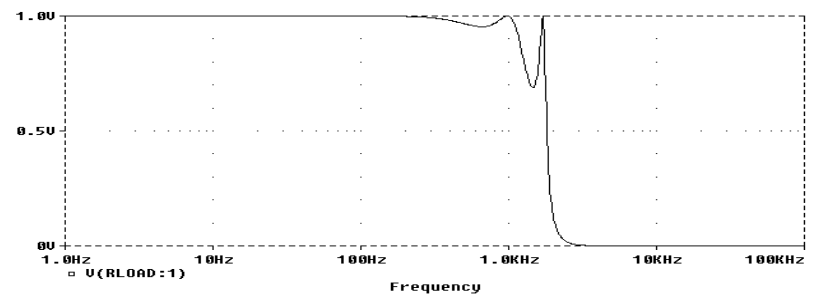


REUSE

\section{LOWPASS FILTER USING ADFS}

GEN 20 - FOUR-RUNG LADDER

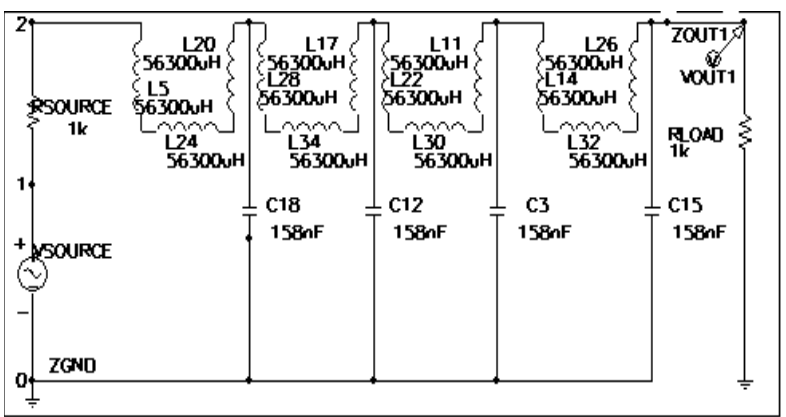

QUADRUPLY-CALLED TWO-PORTED

ADF 0

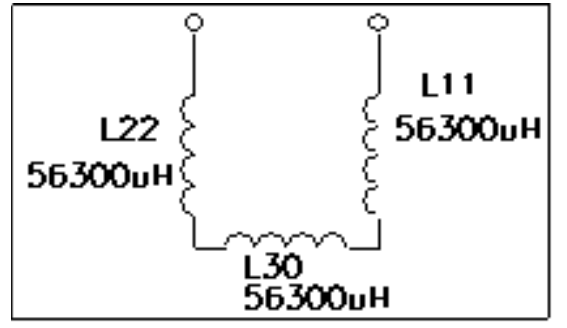

BEHAVIOR IN FREQUENCY DOMAIN

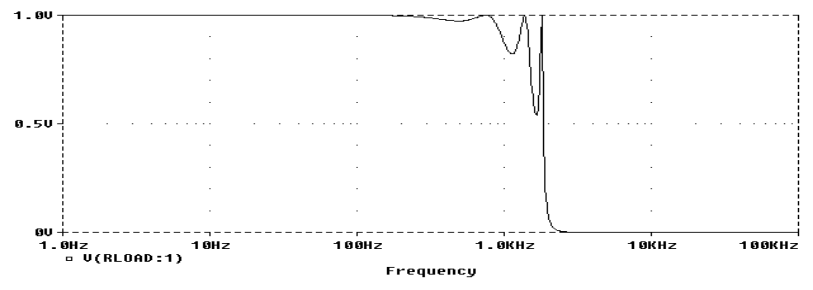




\section{REUSE}

\section{LOWPASS FILTER USING ADFS}

GENERATION 31 - TOPOLOGY OF

CAUER (ELLIPTIC) FILTER

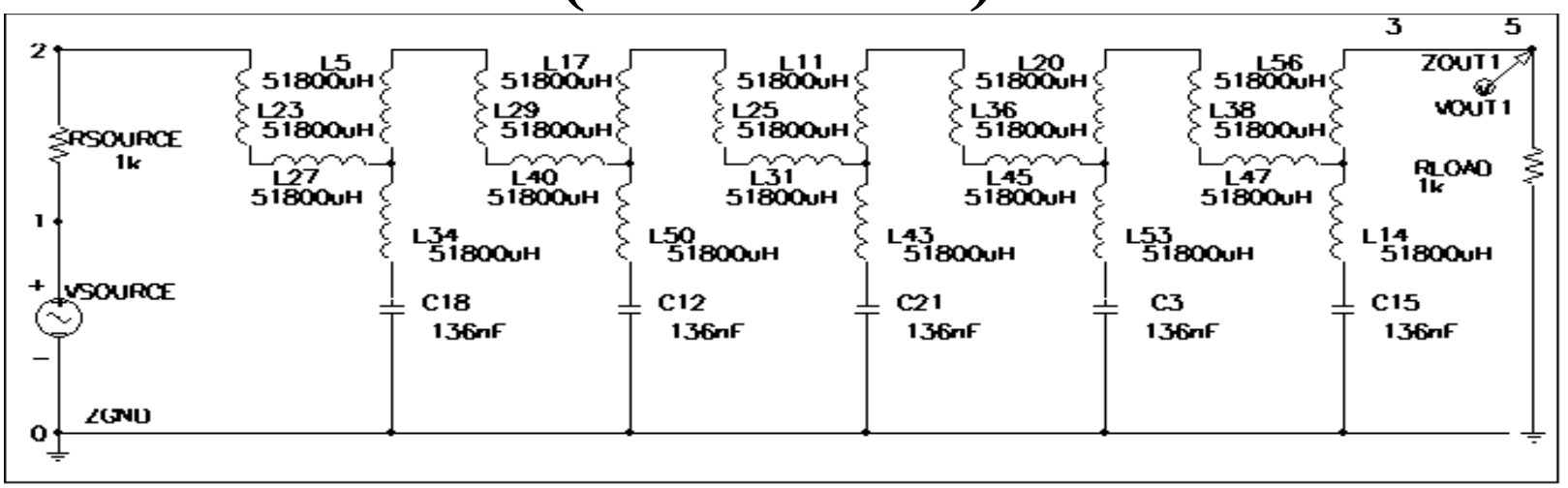

QUINTUPLY-CALLED THREE-PORTED ADF 0

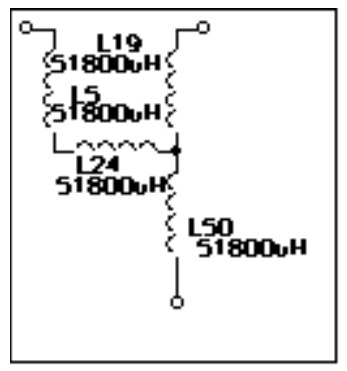

BEHAVIOR IN FREQUENCY DOMAIN

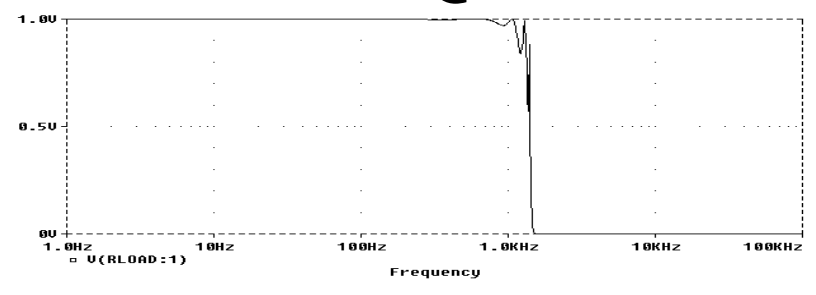




\section{PASSING A PARAMETER TO A SUBSTRUCTURE}

- The set of potential terminals for each constructioncontinuing subtree of an automatically defined function, Tccs-adf-potential, is

$T_{\text {ccs-adf-potential }}=\{$ ARGO $\}$

EMERGENCE OF A PARAMETERIZED

ARGUMENT IN A CIRCUIT SUBSTRUCTURE

HIERARCHY OF BRANCHES FOR THE BEST-OF-RUN CIRCUIT- FROM GENERATION 158

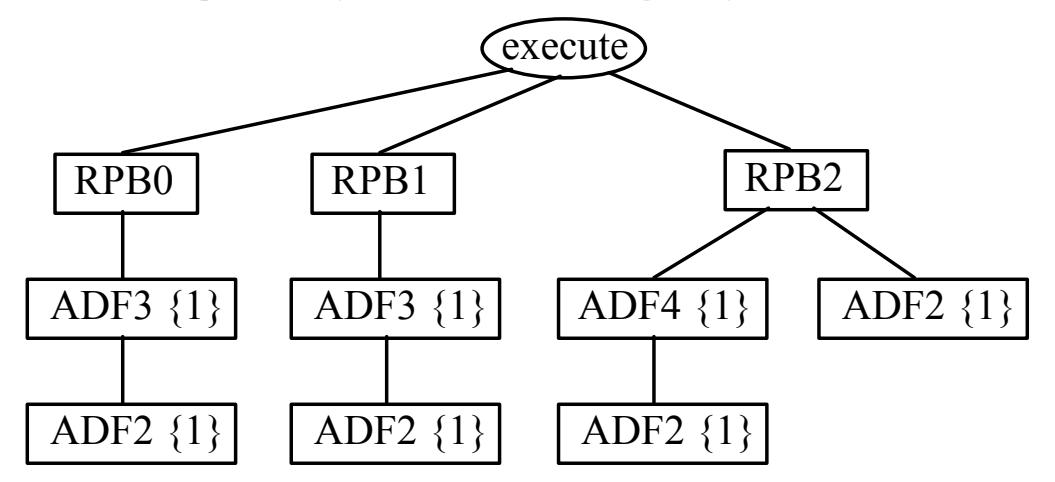




\section{PASSING A PARAMETER TO A SUBSTRUCTURE}

\section{BEST-OF-RUN CIRCUIT FROM GENERATION 158}

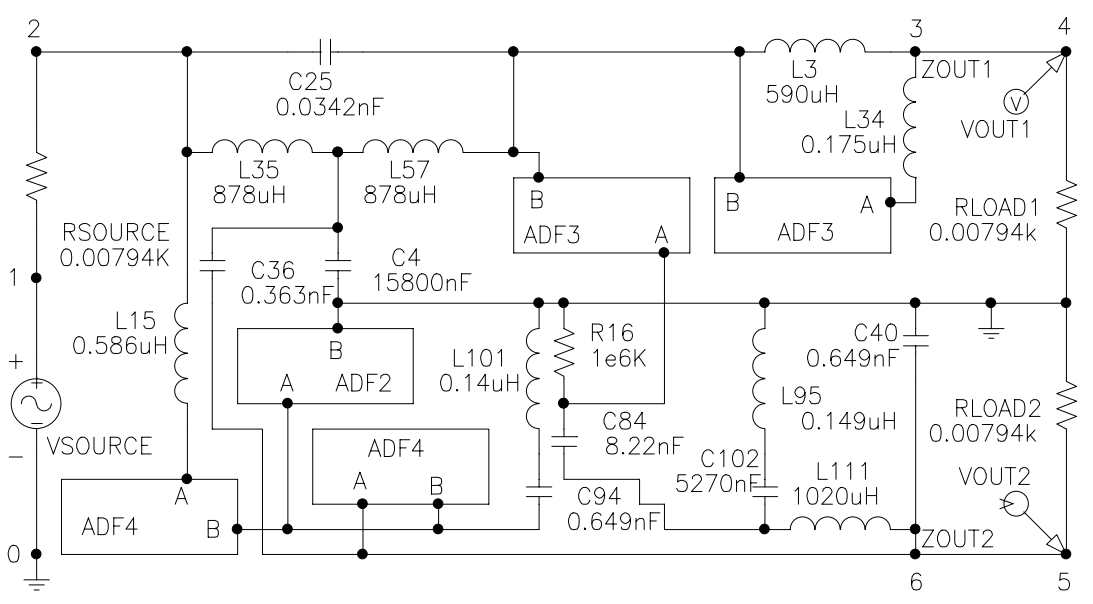




\section{THREE-PORTED AUTOMATICALLY DEFINED FUNCTION ADF 3 OF THE BEST-OF-RUN CIRCUIT FROM GENERATION 158}

\section{ADF 3 CONTAINS CAPACITOR C39 PARAMETERIZED BY DUMMY VARIABLE ARGO}

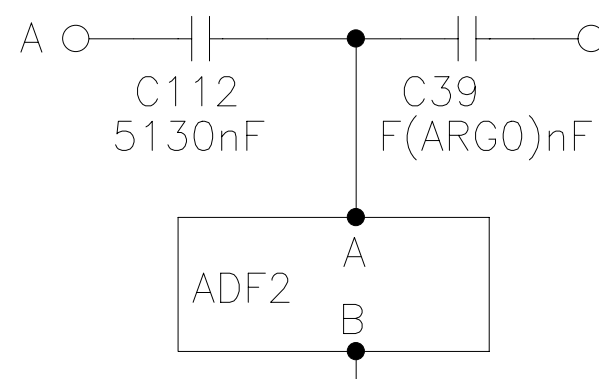




\section{THE FIRST RESULT-PRODUCING BRANCH, RPBO, CALLING ADF 3}

(PARALLELO (L $(+\quad(-1.883196 \mathrm{E}-01 \quad(--9.095883 \mathrm{E}-02$ 5.724576E$01))(-9.737455 \mathrm{E}-01-9.452780 \mathrm{E}-01))($ FLIP END)) (SERIES (C (+ $(+-6.668774 \mathrm{E}-01-8.770285 \mathrm{E}-01)$ 4.587758E-02) (NOP END)) (SERIES END END (PARALLEL1 END END END END)) (FLIP $(\mathrm{SAFE}$ _CUT $))$ ) (PAIR_CONNECT_0 END END END) (PAIR_CONNECT_0 (L $(+-7.220122 \mathrm{E}-01 \quad 4.896697 \mathrm{E}-01)$ END) $\quad(\mathrm{L} \quad(--7.195599 \mathrm{E}-01$ $3.651142 \mathrm{E}-02) \quad$ (SERIES (C $(+-5.111248 \mathrm{E}-01 \quad(-\quad(--6.137950 \mathrm{E}-01$ $-5.111248 \mathrm{E}-01)(-1.883196 \mathrm{E}-01 \quad(--9.095883 \mathrm{E}-02 \quad 5.724576 \mathrm{E}-$ 01)))) END) (SERIES END END (adf3 6.196514E-01)) (NOP END))) (NOP END)) )

\section{AUTOMATICALLY DEFINED FUNCTION ADF 3}

(C $1_{+}(-)_{+}(+(+5.630820 \mathrm{E}-01 \quad(-9.737455 \mathrm{E}-01$-9.452780E-01) $)$ (+ ARG0 6.953752E-02) $)(-(-5.627716 \mathrm{E}-02 \quad(+2.273517 \mathrm{E}-01 \quad(+$ $1.883196 \mathrm{E}-01(+9.346950 \mathrm{E}-02(+-7.220122 \mathrm{E}-01 \quad(+2.710414 \mathrm{E}-02$ $1.397491 \mathrm{E}-02)))))(-(+(-2.710414 \mathrm{E}-02-2.807583 \mathrm{E}-01) \quad(+-$ $6.137950 \mathrm{E}-01-8.554120 \mathrm{E}-01))(--8.770285 \mathrm{E}-01(--4.049602 \mathrm{E}-01$ $-2.192044 \mathrm{E}-02)))))(+(+1.883196 \mathrm{E}-01(+(+(+(+9.346950 \mathrm{E}-02$ $(+-7.220122 \mathrm{E}-01(+2.710414 \mathrm{E}-021.397491 \mathrm{E}-02)))(-4.587758 \mathrm{E}-$ $02-2.340137 \mathrm{E}-01)) 3.226026 \mathrm{E}-01)(+-7.220122 \mathrm{E}-01 \quad(-\quad-$

$9.131658 \mathrm{E}-016.595502 \mathrm{E}-01)))) 3.660116 \mathrm{E}-01)) 9.496355 \mathrm{E}-01)$ (THREE_GROUND_0 (C $(+(-)(+(+5.630820 \mathrm{E}-01)(-9.737455 \mathrm{E}-01$ $-9.452780 \mathrm{E}-01))(+(-(--7.195599 \mathrm{E}-013.651142 \mathrm{E}-02) \quad-$ $9.761651 \mathrm{E}-01) \quad(-(+(-(--7.195599 \mathrm{E}-013.651142 \mathrm{E}-02) \quad-$ $9.761651 \mathrm{E}-01) 6.953752 \mathrm{E}-02) 3.651142 \mathrm{E}-02)))(-(-5.627716 \mathrm{E}-02$ $(-1.883196 \mathrm{E}-01 \quad(--9.095883 \mathrm{E}-025.724576 \mathrm{E}-01)))(-(+(-$ $2.710414 \mathrm{E}-02-2.807583 \mathrm{E}-01)(+-6.137950 \mathrm{E}-01$ (+ ARG0 6.953752E-02) $))(--8.770285 \mathrm{E}-01$ (- -4.049602E-01 -2.192044E$02))))(+(+1.883196 \mathrm{E}-01-7.195599 \mathrm{E}-01) \quad 3.660116 \mathrm{E}-01))$ 9.496355E-01) (NOP (FLIP (PAIR_CONNECT_0 END END END)))) (FLIP (SERIES (FLIP (FLIP (FLIP END) )) (C $(-(+6.238477 \mathrm{E}-01$ $6.196514 \mathrm{E}-01)(+(+(-(-4.037348 \mathrm{E}-014.343444 \mathrm{E}-01) \quad(+-$ $7.788187 \mathrm{E}-01 \quad(+(+)-8.786904 \mathrm{E}-011.397491 \mathrm{E}-02) \quad(--$ $6.137950 \mathrm{E}-01 \quad(-(+)(-2.710414 \mathrm{E}-02-2.807583 \mathrm{E}-01) \quad(+-$ $6.137950 \mathrm{E}-01-8.554120 \mathrm{E}-01))(--8.770285 \mathrm{E}-01 \quad(--4.049602 \mathrm{E}-01$ $-2.192044 \mathrm{E}-02)))))(+(+7.215142 \mathrm{E}-031.883196 \mathrm{E}-01) \quad(+$ $7.733750 \mathrm{E}-014.343444 \mathrm{E}-01))))(-(--9.389297 \mathrm{E}-01$ 5.630820E$01)(+-5.840433 \mathrm{E}-02 \quad 3.568947 \mathrm{E}-01)))-8.554120 \mathrm{E}-01))$ (NOP END)) $E N D))(\operatorname{FLIP}(\operatorname{adf2} 9.737455 \mathrm{E}-01))))$ 


\section{ADF 3 DOES THREE THINGS}

- The structure that develops out of $A D F 3$ includes a capacitor $\mathrm{C} 112$ whose value $(5,130 \mathrm{uF})$ is not a function of its dummy variable, ARGO.

- The structure that develops out of ADF3 has one hierarchical reference to $A D F 2$. As previously mentioned, the invocation of $A D F 2$ is done with a constant $(9.737455 E-$ 01) so this invocation of $A D F 2$ produces a $259 \mu \mathrm{H}$ inductor.

- Most importantly, the structure that develops out of $A D F 3$ creates a capacitor (C39) whose sizing, $F(A R G 0)$, is a function of the dummy variable, ARGO, of automatically defined function $A D F 3$. Capacitor C39 has different sizing on different invocations of automatically defined function ADF 3.

- The combined effect of $A D F 3$ is to insert the following three components:

- an unparameterized 5,130 uF capacitor,

- a parameterized capacitor C39 whose component value is dependent on ARGO of ADF 3, and

- a parameterized inductor (created by ADF2) whose sizing is parameterized, but which, in practice, is called with a constant value. 
EMERGENCE OF A PARAMETERIZED

ARGUMENT IN A CIRCUIT SUBSTRUCTURE

HIERARCHY OF BRANCHES FOR THE BEST-OF-RUN CIRCUIT- FROM GENERATION 158

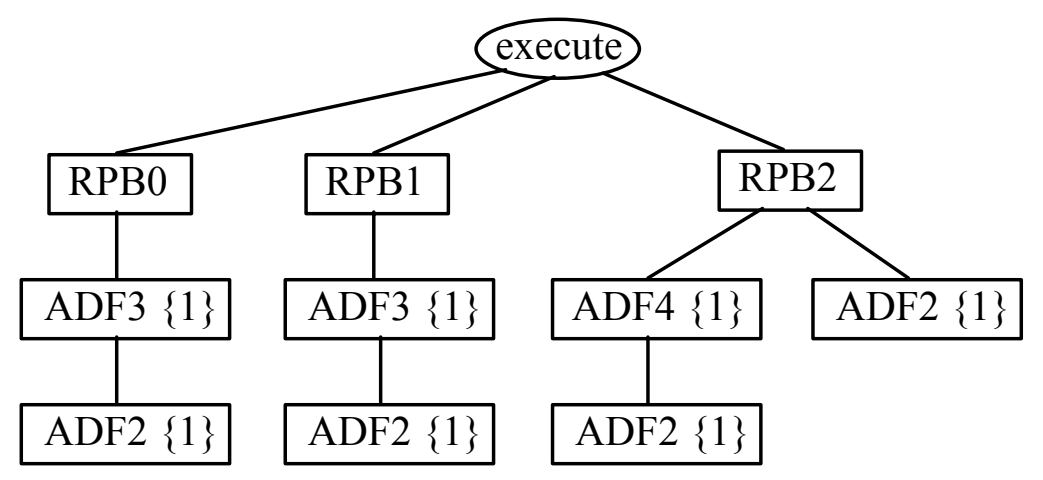




\section{FREE VARIABLE (INPUT) AND CONDITIONALS}

\section{SOLVING A QUADRATIC EQUATION USING THE GENETIC ALGORITHM}

- Suppose we want the 2 roots of the quadratic equation

$$
1 x^{2}-3 x+2=0
$$

- Using the genetic algorithm (GA) operating on a fixedlength character string, we can search a space of encodings using an alphabet size of 2 (i.e., binary) of length, say, 16 representing two real numbers (each with, say, 4 bits to left of the "decimal" point). After running the GA, a solution is

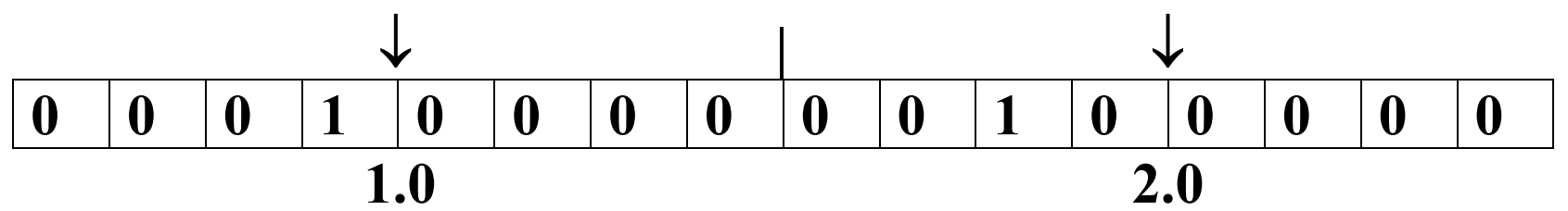

- Alternatively, we could use a "floating point" genetic algorithm (GA) to search a space of 2-part encodings. A solution is

$$
\begin{array}{r|r}
1.0 & 2.0
\end{array}
$$

- In either case, the result is a solution to ONE INSTANCE of the quadratic equation problem. 


\section{SOLVING A QUADRATIC EQUATION USING GENETIC PROGRAMMING (GP)}

- Using genetic programming (GP), we can solve the general, parameterized quadratic equation

$$
a x^{2}+b x+c=0
$$

by searching the space of computer programs for a program that takes $a, b$, and $c$ as inputs

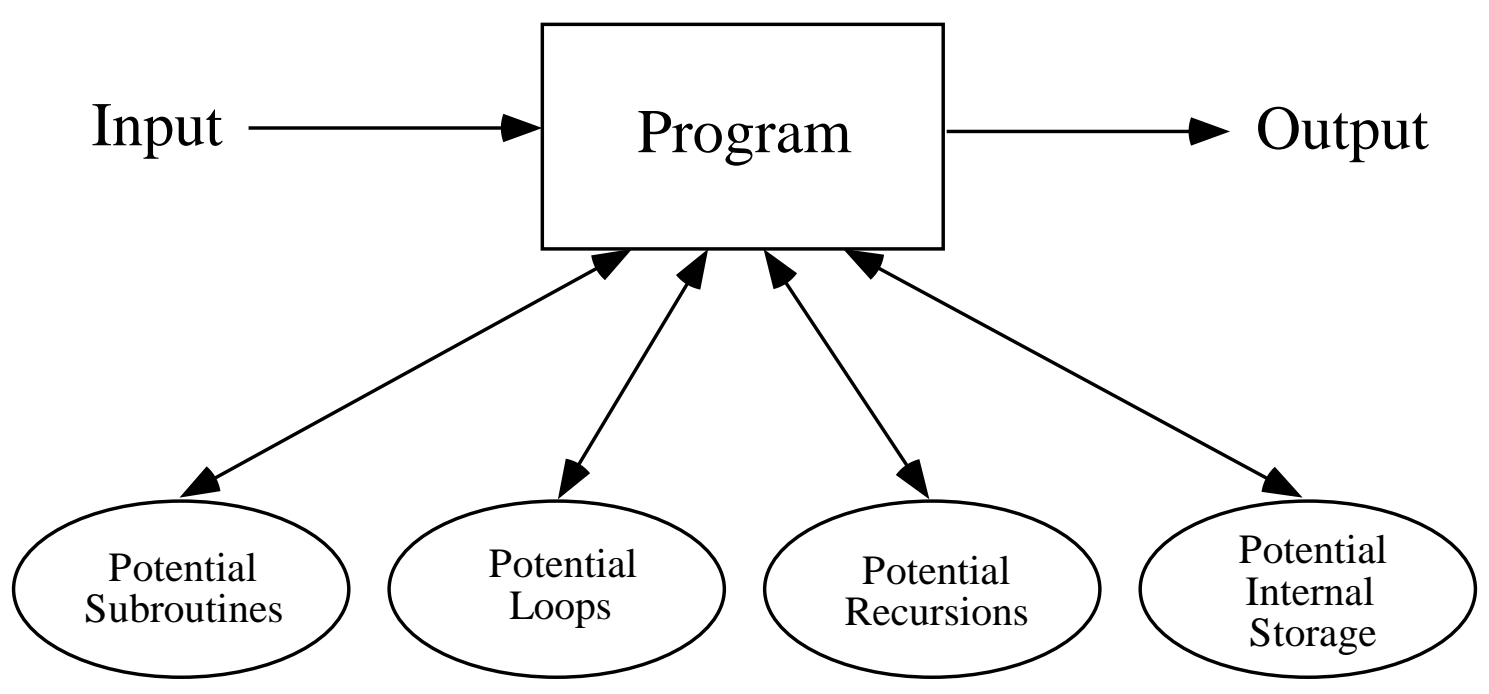

- The result is a solution to ALL INSTANCES of the quadratic equation problem 


\section{GENERAL APPEARANCE OF ONE POSSIBLE CHROMOSOME ENCODING USED TO SOLVE ONE INSTANCE OF A CIRCUIT PROBLEM USING THE GENETIC ALGORITHM (GA) OPERATING ON FIXED-LENGTH CHARACTER STRINGS}

\section{EXAMPLE CIRCUIT}

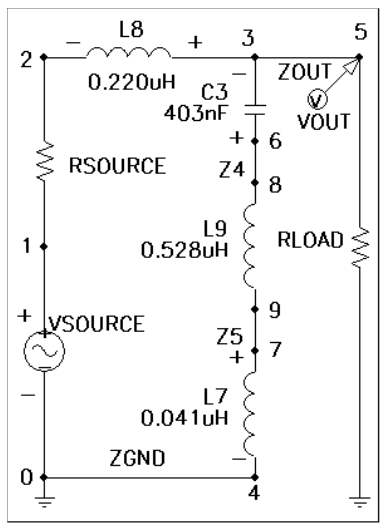

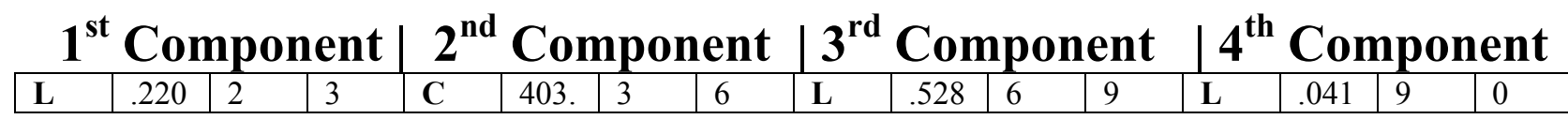


THE GENERAL APPEARANCE OF EXPRESSIONS USED TO SOLVE ONE INSTANCE OF A CIRCUIT PROBLEM USING GENETIC PROGRAMMING (GP) IN GENETIC PROGRAMMING III (1999)

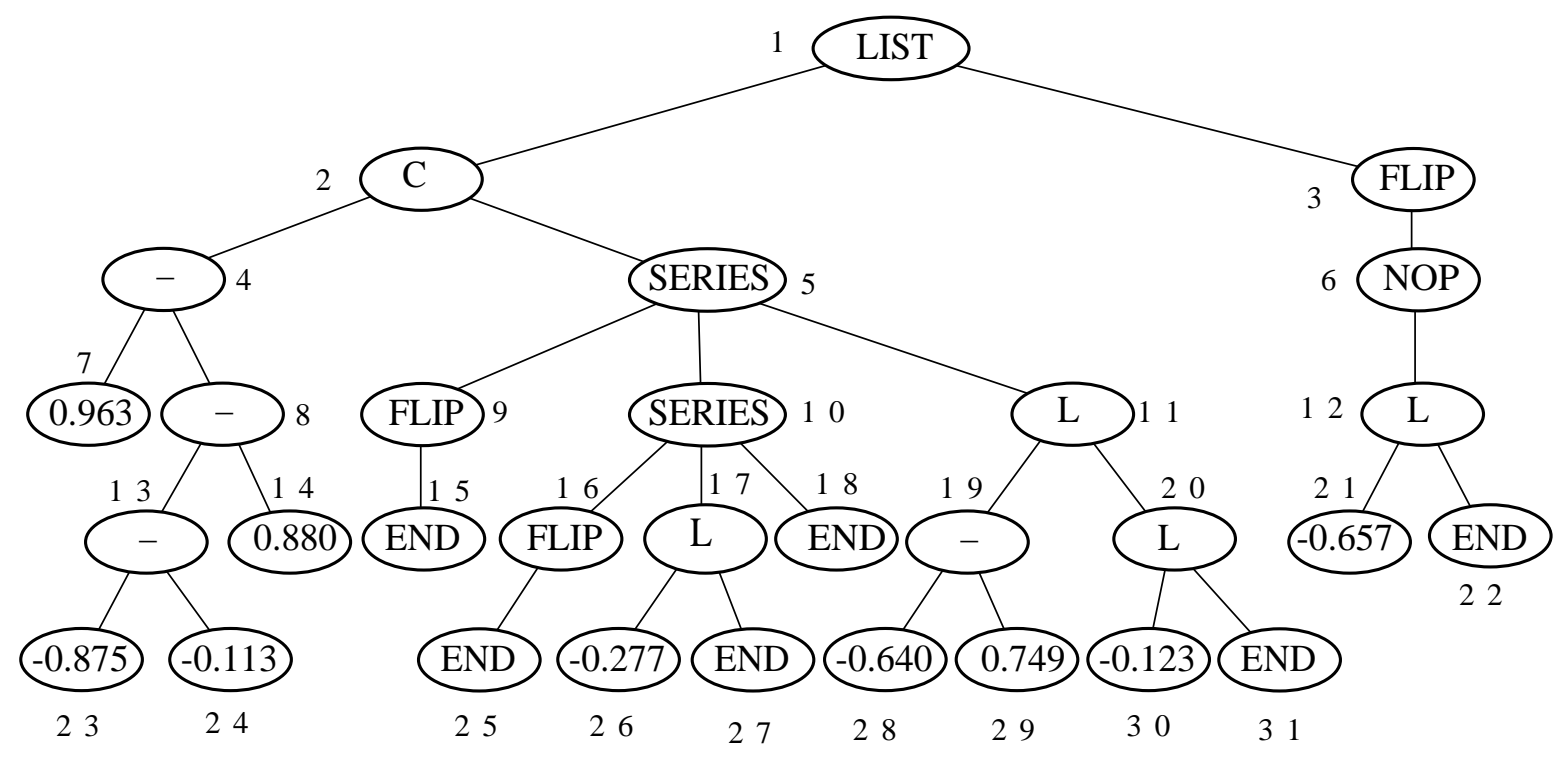

(LIST (C (- $0.963(-(--0.875-0.113) 0.880))$ (series (flip end) (series (flip end) ( $L-0.277$ end) end) ( $\mathrm{L}$ ( -0.640 $0.749)(\mathrm{L}-0.123$ end $))))(\operatorname{flip}(\operatorname{nop}(\mathrm{L}-0.657$ end $)))))$ EXAMPLE CIRCUIT (GEN 0)

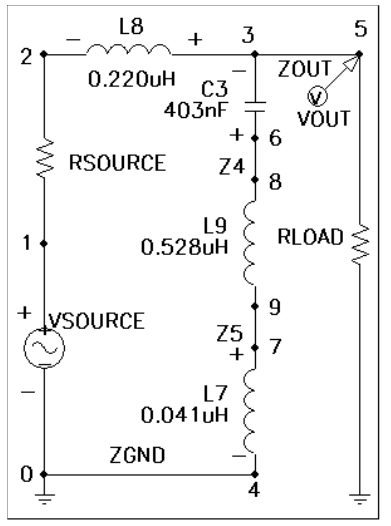




\section{VALUE-SETTING SUBTREES-3 WAYS}

\section{ARITHMETIC-PERFORMING SUBTREE}

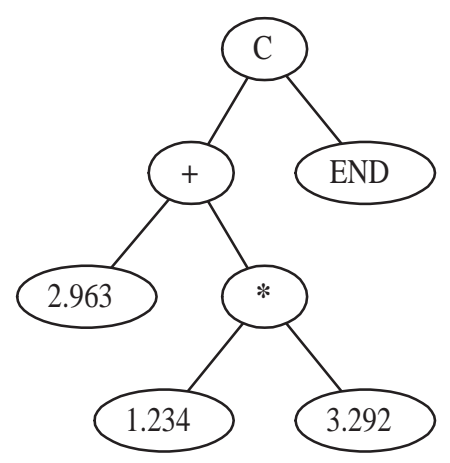

SINGLE PERTURBABLE CONSTANT
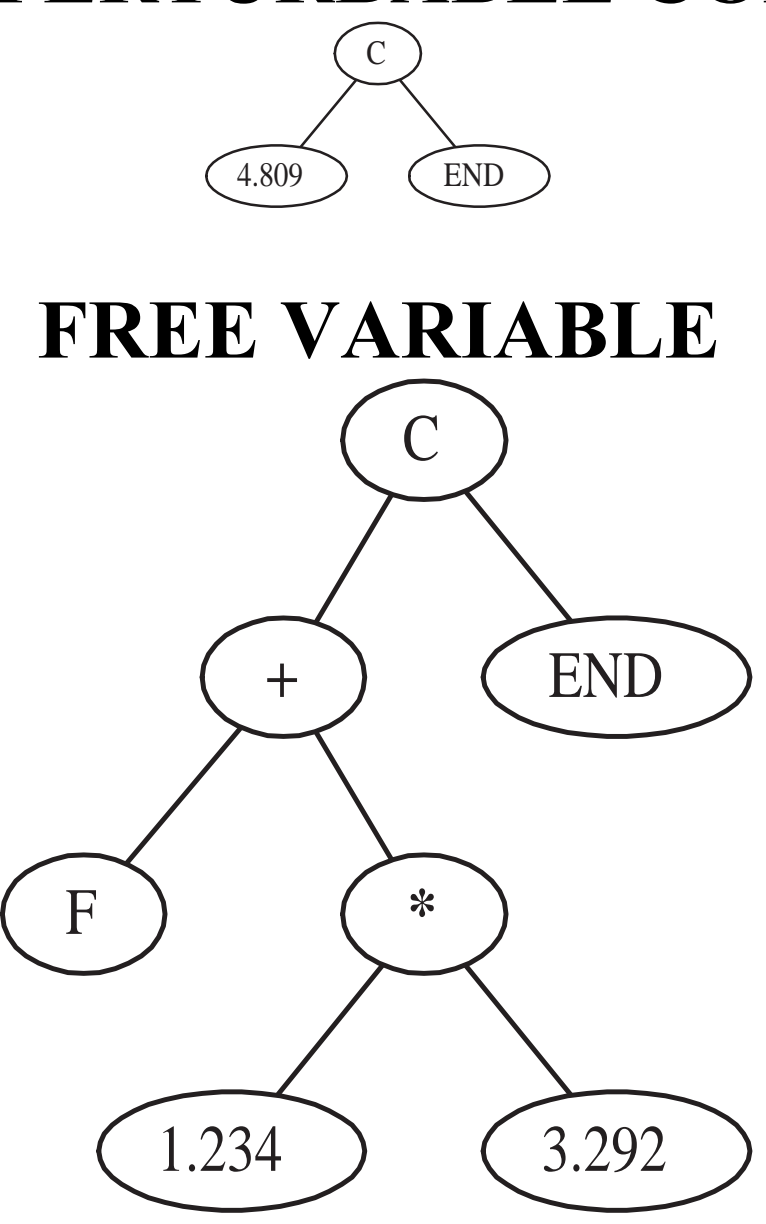


\section{PARAMETERIZED TOPOLOGY FOR "GENERALIZED" LOWPASS FILTER}

\section{VARIABLE CUTOFF LOWPASS FILTER}

-Want lowpass filter whose passband ends at frequencies $f=$ $1,000,1,780,3,160,5,620,10,000,17,800,31,600,56,200$, $100,000 \mathrm{~Hz}$

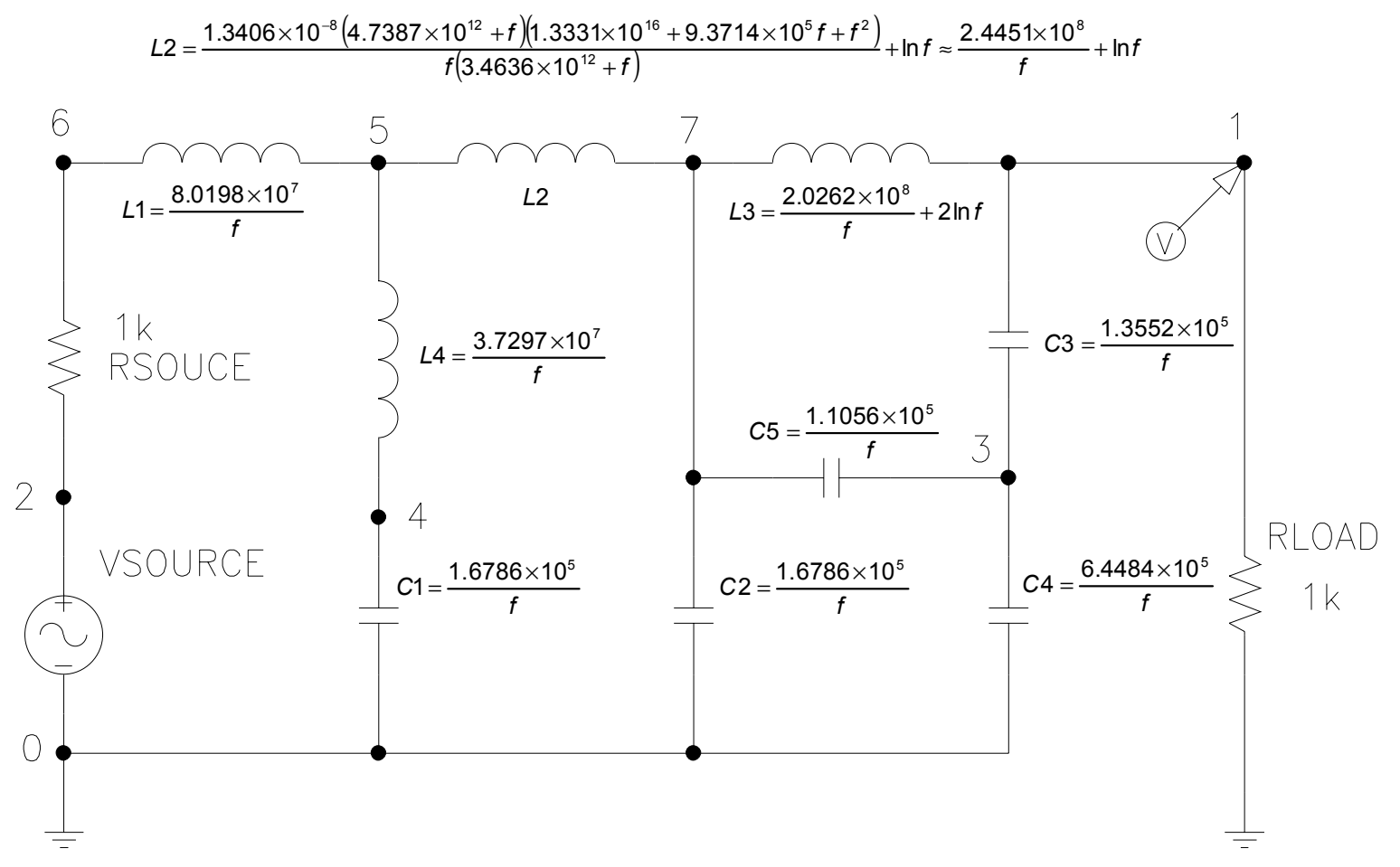




\section{PARAMETERIZED TOPOLOGY USING CONDITIONAL DEVELOPMENTAL OPERATORS (GENETIC SWITCH)}

\section{VARIABLE-CUTOFF LOWPASS/HIGHPASS FILTER CIRCUIT}

- Best-of-run circuit from generation 93 when inputs call for a highpass filter (i.e., F1 > F2).

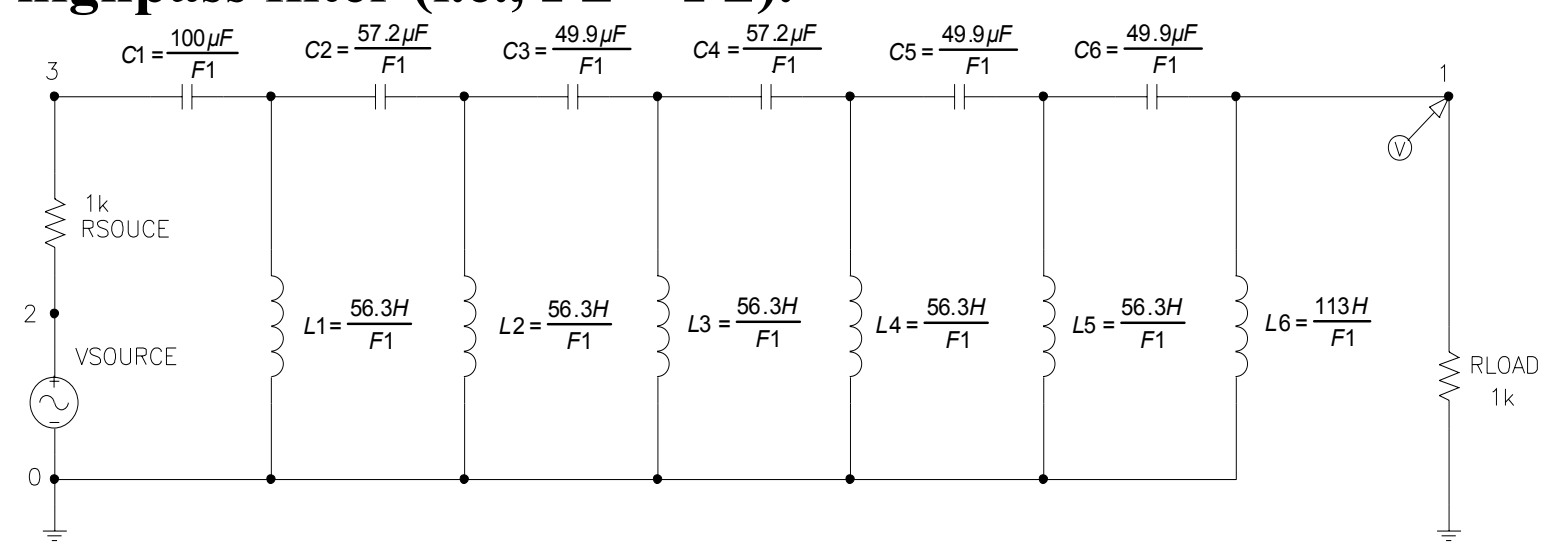

- Best-of-run circuit from generation 93 when inputs call for a lowpass filter.

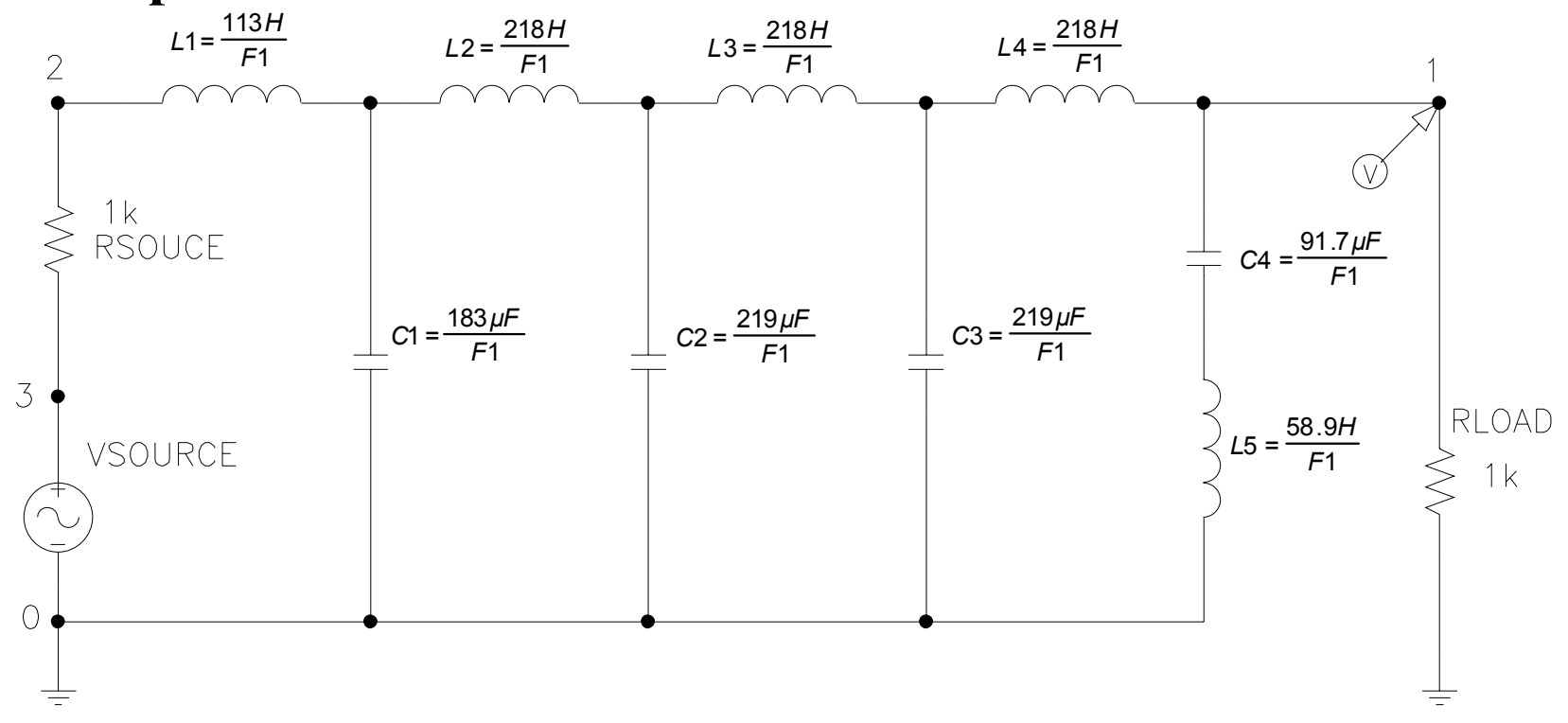




\section{PARALLELIZATION BY \\ SUBPOPULATIONS ("ISLAND" OR \\ "DEME" MODEL OR "DISTRIBUTED \\ GENETIC ALGORITHM")}

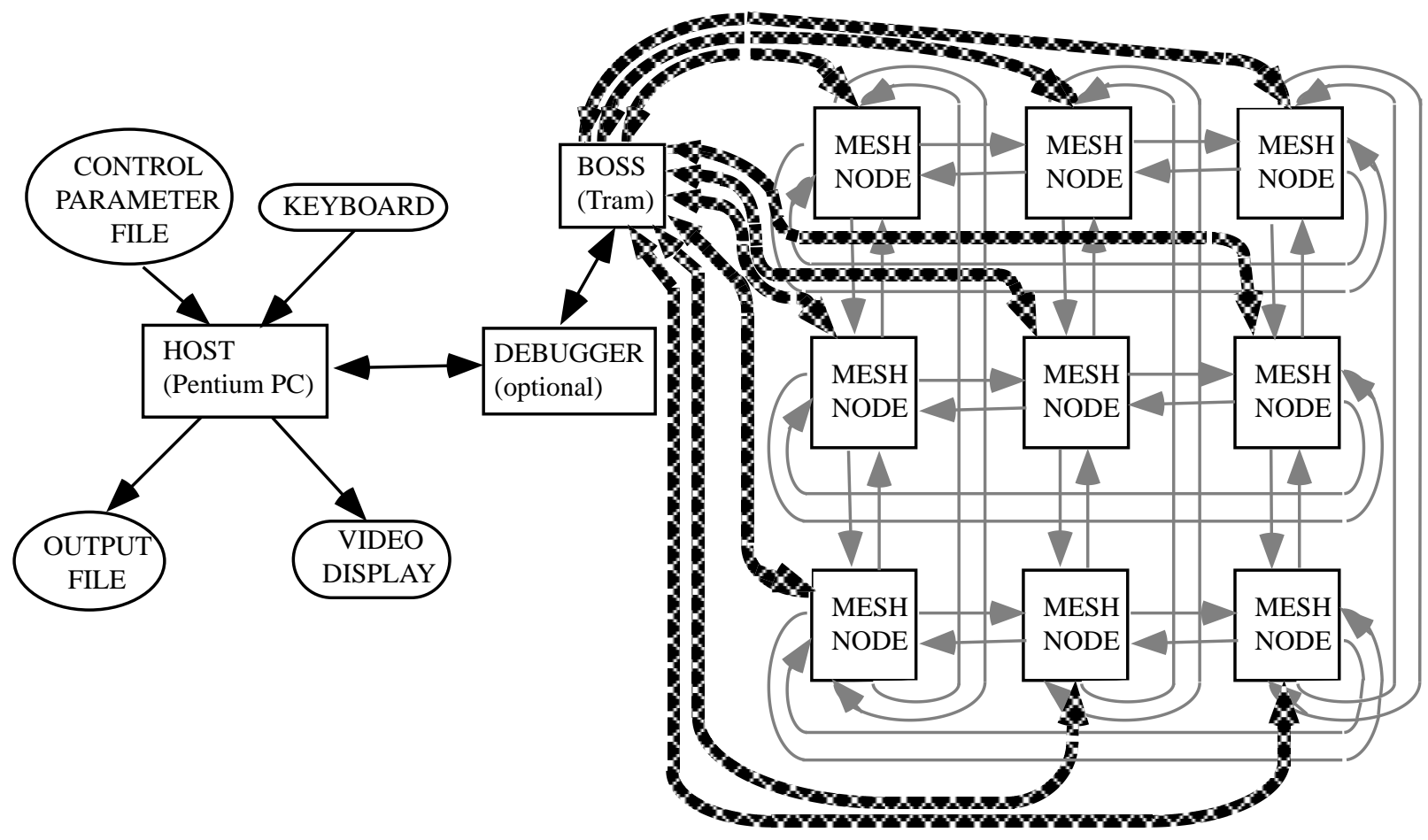

- Like Hormel, Get Everything Out of the Pig, Including the Oink

- Keep on Trucking

- It Takes a Licking and Keeps on Ticking

- The Whole is Greater than the Sum of the Parts

\section{PETA-OPS}

- Human brain operates at 1012 neurons operating at 103 per second $=1015$ ops per second - 1015 ops $=1$ peta-op $=1$ bs (brain second) 


\section{GENETIC PROGRAMMING OVER 15- YEAR PERIOD 1987-2002}

\begin{tabular}{|c|c|c|c|c|c|}
\hline System & $\begin{array}{r}\text { Period } \\
\text { of } \\
\text { usage }\end{array}$ & $\begin{array}{r}\text { Petacycles } \\
\left(10^{15} \text { cycles }\right) \\
\text { per day for } \\
\text { entire } \\
\text { system }\end{array}$ & $\begin{array}{r}\text { Speed-up } \\
\text { over } \\
\text { previous } \\
\text { system }\end{array}$ & $\begin{array}{l}\text { Speed-up } \\
\text { over first } \\
\text { system in } \\
\text { this table }\end{array}$ & $\begin{array}{r}\text { Human- } \\
\text { competitive } \\
\text { results }\end{array}$ \\
\hline $\begin{array}{l}\text { Serial } \\
\text { Texas } \\
\text { Instruments } \\
\text { LISP } \\
\text { machine }\end{array}$ & $\begin{array}{r}1987- \\
1994\end{array}$ & 0.00216 & 1 (base) & 1 (base) & $\mathbf{0}$ \\
\hline $\begin{array}{l}\text { 64-node } \\
\text { Transtech } \\
\text { transputer } \\
\text { parallel } \\
\text { machine }\end{array}$ & $\begin{array}{r}1994- \\
1997\end{array}$ & 0.02 & 9 & 9 & 2 \\
\hline $\begin{array}{l}\text { 64-node } \\
\text { Parsytec } \\
\text { parallel } \\
\text { machine }\end{array}$ & $\begin{array}{r}1995- \\
2000\end{array}$ & 0.44 & 22 & 204 & 12 \\
\hline $\begin{array}{l}70 \text {-node } \\
\text { Alpha } \\
\text { parallel } \\
\text { machine }\end{array}$ & $\begin{array}{r}1999- \\
2001\end{array}$ & 3.2 & 7.3 & 1,481 & 2 \\
\hline $\begin{array}{l}\text { 1,000-node } \\
\text { Pentium II } \\
\text { parallel } \\
\text { machine }\end{array}$ & $\begin{array}{r}2000- \\
2002\end{array}$ & 30.0 & 9.4 & 13,900 & 12 \\
\hline
\end{tabular}




\section{PROGRESSION OF RESULTS}

\begin{tabular}{|c|c|c|c|}
\hline System & Period & $\begin{array}{r}\text { Speed- } \\
\text { up }\end{array}$ & $\begin{array}{l}\text { Qualitative nature of the results produced } \\
\text { by genetic programming }\end{array}$ \\
\hline $\begin{array}{l}\text { Serial LISP } \\
\text { machine }\end{array}$ & $\begin{array}{r}1987- \\
1994\end{array}$ & 1 (base) & $\begin{array}{l}\text { - Toy problems of the } 1980 \text { s and early } \\
1990 \text { s from the fields of artificial } \\
\text { intelligence and machine learning }\end{array}$ \\
\hline $\begin{array}{l}\text { 64-node } \\
\text { Transtech } \\
\text { 8-biy } \\
\text { transputer }\end{array}$ & $\begin{array}{r}1994- \\
1997\end{array}$ & 9 & $\begin{array}{l}\text {-Two human-competitive results involving } \\
\text { one-dimensional discrete data (not patent- } \\
\text { related) }\end{array}$ \\
\hline $\begin{array}{l}\text { 64-node } \\
\text { Parsytec } \\
\text { parallel } \\
\text { machine }\end{array}$ & $\begin{array}{r}1995- \\
2000\end{array}$ & 22 & $\begin{array}{l}\text { - One human-competitive result involving } \\
\text { two-dimensional discrete data } \\
\text { - Numerous human-competitive results } \\
\text { involving continuous signals analyzed in } \\
\text { the frequency domain } \\
\text { - Numerous human-competitive results } \\
\text { involving } 20^{\text {th }} \text {-century patented inventions }\end{array}$ \\
\hline $\begin{array}{l}\text { 70-node } \\
\text { Alpha } \\
\text { parallel } \\
\text { machine }\end{array}$ & $\begin{array}{r}1999- \\
2001\end{array}$ & 7.3 & $\begin{array}{l}\text { - One human-competitive result involving } \\
\text { continuous signals analyzed in the time } \\
\text { domain } \\
\text { - Circuit synthesis extended from topology } \\
\text { and sizing to include routing and } \\
\text { placement (layout) }\end{array}$ \\
\hline $\begin{array}{l}\text { 1,000-node } \\
\text { Pentium II } \\
\text { parallel } \\
\text { machine }\end{array}$ & $\begin{array}{r}2000- \\
2002\end{array}$ & 9.4 & $\begin{array}{l}\text { - Numerous human-competitive results } \\
\text { involving continuous signals analyzed in } \\
\text { the time domain } \\
\text { - Numerous general solutions to problems } \\
\text { in the form of parameterized topologies } \\
\text { - Six human-competitive results } \\
\text { duplicating the functionality of } 21^{\text {st }} \text { - } \\
\text { century patented inventions }\end{array}$ \\
\hline $\begin{array}{l}\text { Long (4- } \\
\text { week) runs } \\
\text { of } 1,000- \\
\text { node } \\
\text { Pentium II } \\
\text { parallel } \\
\text { machine }\end{array}$ & 2002 & 9.3 & $\begin{array}{l}\text { - Generation of two patentable new } \\
\text { inventions }\end{array}$ \\
\hline
\end{tabular}




\section{PROGRESSION OF QUALITATIVELY} MORE SUBSTANTIAL RESULTS PRODUCED BY GENETIC PROGRAMMING IN RELATION TO FIVE ORDER-OF-MAGNITUDE INCREASES IN COMPUTATIONAL POWER

- toy problems

- human-competitive results not related to patented inventions

- $20^{\text {th }}$-century patented inventions

- $21^{\text {st }}$-century patented inventions

- patentable new inventions 


\section{EVOLVABLE HARDWARE}

\section{RAPIDLY RECONFIGURABLE FIELD- PROGRAMMABLE GATE ARRAYS (FPGAs)}

\section{SMALL 5 BY 5 CORNER OF XILINX XC6216 FPGA}

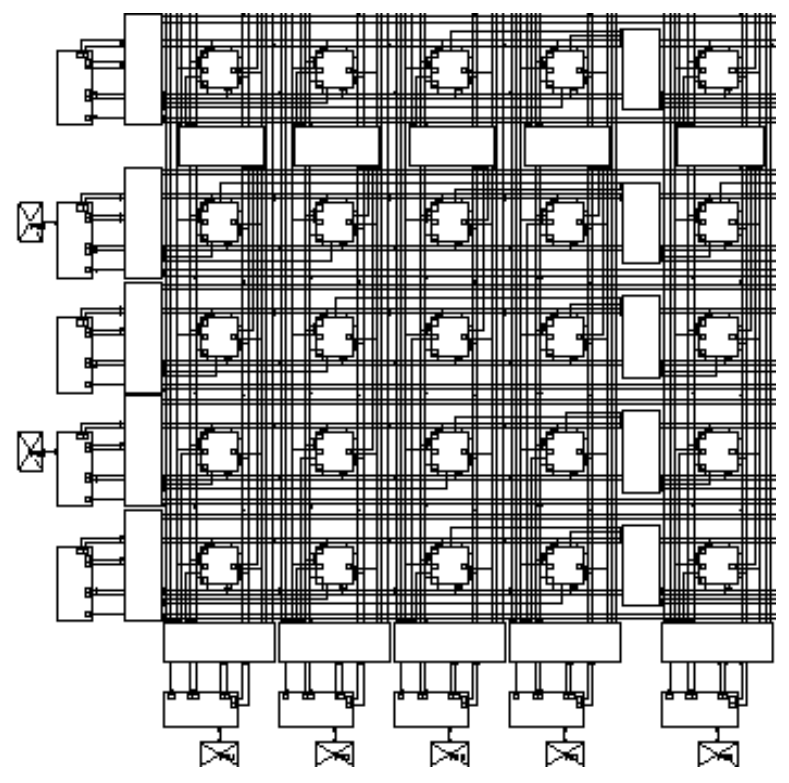




\section{EVOLVABLE HARDWARE}

\section{RAPIDLY RECONFIGURABLE FIELD- PROGRAMMABLE GATE ARRAYS (FPGAs)}

\section{SORTING NETWORKS}

- A 16-step 7-sorter was evolved that has two fewer steps than the sorting network described in $O^{\prime}$ Connor and Nelsons' patent (1962) and that has the same number of steps as the 7-sorter that was devised by Floyd and Knuth subsequent to the patent and described in Knuth 1973.

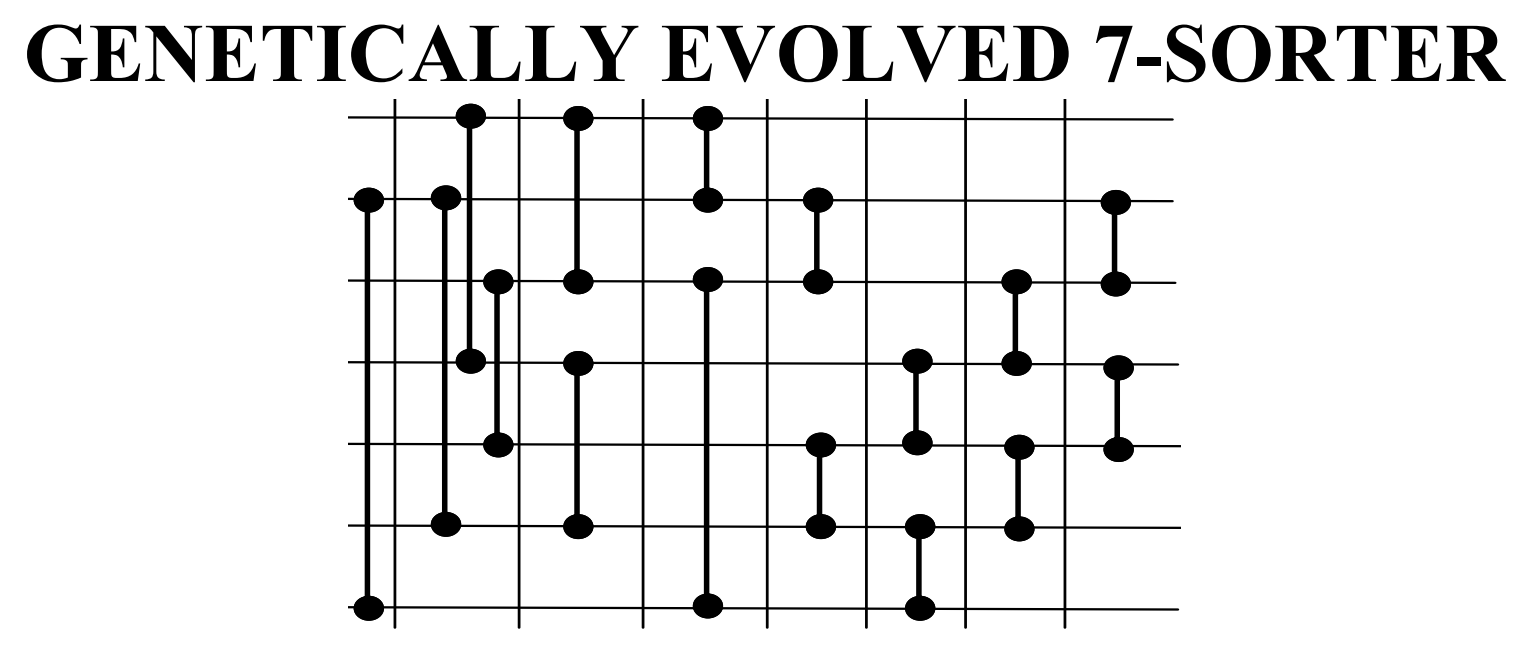




\section{FUNDAMENTAL DIFFERENCES BETWEEN GP AND OTHER APPROACHES TO AI AND ML}

(1) Representation: Genetic programming overtly conducts it search for a solution to the given problem in program space.

(2) Role of point-to-point transformations in the search: Genetic programming does not conduct its search by transforming a single point in the search space into another single point, but instead transforms a set of points into another set of points.

(3) Role of hill climbing in the search: Genetic programming does not rely exclusively on greedy hill climbing to conduct its search, but instead allocates a certain number of trials, in a principled way, to choices that are known to be inferior.

(4) Role of determinism in the search: Genetic programming conducts its search probabilistically.

(5) Role of an explicit knowledge base: None.

(6) Role of formal logic in the search: None.

(7) Underpinnings of the technique: Biologically inspired. 


\section{HUMAN-COMPETITIVE RESULTS (LIST AS OF MAY 2003)}

\begin{tabular}{|c|c|c|c|}
\hline & Claimed instance & $\begin{array}{l}\text { Basis for claim } \\
\text { of human- } \\
\text { competitiveness }\end{array}$ & Reference \\
\hline 1 & $\begin{array}{l}\text { Creation of a better-than-classical quantum } \\
\text { algorithm for the Deutsch-Jozsa "early } \\
\text { promise" problem }\end{array}$ & $\mathbf{B}, \mathbf{F}$ & $\begin{array}{l}\text { Spector, Barnum, and } \\
\text { Bernstein } 1998\end{array}$ \\
\hline 2 & $\begin{array}{l}\text { Creation of a better-than-classical quantum } \\
\text { algorithm for Grover's database search } \\
\text { problem }\end{array}$ & B, F & $\begin{array}{l}\text { Spector, Barnum, and } \\
\text { Bernstein } 1999\end{array}$ \\
\hline 3 & $\begin{array}{l}\text { Creation of a quantum algorithm for the depth- } \\
\text { two AND/OR query problem that is better than } \\
\text { any previously published result }\end{array}$ & D & $\begin{array}{l}\text { Spector, Barnum, Bernstein, } \\
\text { and Swamy 1999; Barnum, } \\
\text { Bernstein, and Spector } 2000\end{array}$ \\
\hline 4 & $\begin{array}{l}\text { Creation of a quantum algorithm for the depth- } \\
\text { one OR query problem that is better than any } \\
\text { previously published result }\end{array}$ & D & $\begin{array}{l}\text { Barnum, Bernstein, and } \\
\text { Spector } 2000\end{array}$ \\
\hline 5 & $\begin{array}{l}\text { Creation of a protocol for communicating } \\
\text { information through a quantum gate that was } \\
\text { previously thought not to permit such } \\
\text { communication }\end{array}$ & $\mathbf{D}$ & Spector and Bernstein 2003 \\
\hline 6 & $\begin{array}{l}\text { Creation of a novel variant of quantum dense } \\
\text { coding }\end{array}$ & $\mathbf{D}$ & Spector and Bernstein 2003 \\
\hline 7 & $\begin{array}{l}\text { Creation of a soccer-playing program that won } \\
\text { its first two games in the Robo Cup } 1997 \\
\text { competition }\end{array}$ & $\mathbf{H}$ & Luke 1998 \\
\hline 8 & $\begin{array}{l}\text { Creation of a soccer-playing program that } \\
\text { ranked in the middle of the field of } 34 \text { human- } \\
\text { written programs in the Robo Cup } 1998 \\
\text { competition }\end{array}$ & $\mathbf{H}$ & Andre and Teller 1999 \\
\hline 9 & $\begin{array}{l}\text { Creation of four different algorithms for the } \\
\text { transmembrane segment identification problem } \\
\text { for proteins }\end{array}$ & $\mathbf{B}, \mathbf{E}$ & $\begin{array}{l}\text { Sections } 18.8 \text { and } 18.10 \text { of } G P \text { - } \\
2 \text { book and sections } 16.5 \text { and } \\
17.2 \text { of GP-3 book }\end{array}$ \\
\hline 10 & $\begin{array}{l}\text { Creation of a sorting network for seven items } \\
\text { using only } 16 \text { steps }\end{array}$ & A, D & $\begin{array}{l}\text { Sections } 21.4 .4,23.6 \text {, and } \\
57.8 .1 \text { of GP-3 book }\end{array}$ \\
\hline 11 & $\begin{array}{l}\text { Rediscovery of the Campbell ladder topology } \\
\text { for lowpass and highpass filters }\end{array}$ & $\mathbf{A}, \mathbf{F}$ & $\begin{array}{l}\text { Section } 25.15 .1 \text { of GP-3 book } \\
\text { and section } 5.2 \text { of GP-4 book }\end{array}$ \\
\hline 12 & $\begin{array}{l}\text { Rediscovery of the Zobel " } M \text {-derived half } \\
\text { section" and "constant } K \text { " filter sections }\end{array}$ & $\mathbf{A}, \mathbf{F}$ & Section 25.15 .2 of GP-3 book \\
\hline 13 & $\begin{array}{l}\text { Rediscovery of the Cauer (elliptic) topology for } \\
\text { filters }\end{array}$ & $\mathbf{A}, \mathbf{F}$ & Section 27.3.7 of GP-3 book \\
\hline 14 & $\begin{array}{l}\text { Automatic decomposition of the problem of } \\
\text { synthesizing a crossover filter }\end{array}$ & $\mathbf{A}, \mathbf{F}$ & Section 32.3 of GP-3 book \\
\hline 15 & $\begin{array}{l}\text { Rediscovery of a recognizable voltage gain } \\
\text { stage and a Darlington emitter-follower section } \\
\text { of an amplifier and other circuits }\end{array}$ & $\mathbf{A}, \mathbf{F}$ & Section 42.3 of GP-3 book \\
\hline 16 & Synthesis of 60 and 96 decibel amplifiers & $\mathbf{A}, \mathbf{F}$ & Section 45.3 of GP-3 book \\
\hline 17 & $\begin{array}{l}\text { Synthesis of analog computational circuits for } \\
\text { squaring, cubing, square root, cube root, } \\
\text { logarithm, and Gaussian functions }\end{array}$ & $\mathbf{A}, \mathbf{D}, \mathbf{G}$ & Section 47.5.3 of GP-3 book \\
\hline 18 & $\begin{array}{l}\text { Synthesis of a real-time analog circuit for time- } \\
\text { optimal control of a robot }\end{array}$ & $\mathbf{G}$ & Section 48.3 of GP-3 book \\
\hline
\end{tabular}




\begin{tabular}{|c|c|c|c|}
\hline 19 & Synthesis of an electronic thermometer & $\mathbf{A}, \mathbf{G}$ & Section 49.3 of GP-3 book \\
\hline 20 & Synthesis of a voltage reference circuit & $\mathbf{A}, \mathbf{G}$ & Section 50.3 of GP-3 book \\
\hline 21 & $\begin{array}{l}\text { Creation of a cellular automata rule for the } \\
\text { majority classification problem that is better } \\
\text { than the Gacs-Kurdyumov-Levin (GKL) rule } \\
\text { and all other known rules written by humans }\end{array}$ & $\mathbf{D}, \mathbf{E}$ & $\begin{array}{l}\text { Andre, Bennett, and Koza } \\
1996 \text { and section } 58.4 \text { of GP-3 } \\
\text { book }\end{array}$ \\
\hline 22 & $\begin{array}{l}\text { Creation of motifs that detect the } \mathrm{D}-\mathrm{E}-\mathrm{A}-\mathrm{D} \\
\text { box family of proteins and the manganese } \\
\text { superoxide dismutase family }\end{array}$ & $\mathbf{C}$ & Section 59.8 of GP-3 book \\
\hline 23 & $\begin{array}{l}\text { Synthesis of topology for a PID-D2 } \\
\text { (proportional, integrative, derivative, and } \\
\text { second derivative) controller }\end{array}$ & $\mathbf{A}, \mathbf{F}$ & Section 3.7 of GP-4 book \\
\hline 24 & $\begin{array}{l}\text { Synthesis of an analog circuit equivalent to } \\
\text { Philbrick circuit }\end{array}$ & $\mathbf{A}, \mathbf{F}$ & Section 4.3 of GP-4 book \\
\hline 25 & Synthesis of a NAND circuit & $\mathbf{A}, \mathbf{F}$ & Section 4.4 of GP-4 book \\
\hline 26 & $\begin{array}{l}\text { Simultaneous synthesis of topology, sizing, } \\
\text { placement, and routing of analog electrical } \\
\text { circuits }\end{array}$ & A. F, $\mathbf{G}$ & Chapter 5 of GP-4 book \\
\hline 27 & $\begin{array}{l}\text { Synthesis of topology for a PID (proportional, } \\
\text { integrative, and derivative) controller }\end{array}$ & $\mathbf{A}, \mathbf{F}$ & Section 9.2 of GP-4 book \\
\hline 28 & Rediscovery of negative feedback & $\mathbf{A}, \mathbf{E}, \mathbf{F}, \mathbf{G}$ & Chapter 14 of GP-4 book \\
\hline 29 & Synthesis of a low-voltage balun circuit & A & Section 15.4.1 of GP-4 book \\
\hline 30 & $\begin{array}{l}\text { Synthesis of a mixed analog-digital variable } \\
\text { capacitor circuit }\end{array}$ & A & Section 15.4.2 of GP-4 book \\
\hline 31 & Synthesis of a high-current load circuit & A & Section 15.4.3 of GP-4 book \\
\hline 32 & $\begin{array}{l}\text { Synthesis of a voltage-current conversion } \\
\text { circuit }\end{array}$ & A & Section 15.4.4 of GP-4 book \\
\hline 33 & Synthesis of a Cubic function generator & A & Section 15.4.5 of GP-4 book \\
\hline 34 & Synthesis of a tunable integrated active filter & A & Section 15.4.6 of GP-4 book \\
\hline 35 & $\begin{array}{l}\text { Creation of PID tuning rules that outperform } \\
\text { the Ziegler-Nichols and Åström-Hägglund } \\
\text { tuning rules }\end{array}$ & A, B, D, E, F, G & Chapter 12 of GP-4 book \\
\hline 36 & $\begin{array}{l}\text { Creation of three non-PID controllers that } \\
\text { outperform a PID controller that uses the } \\
\text { Ziegler-Nichols or Åström-Hägglund tuning } \\
\text { rules }\end{array}$ & $\mathbf{A}, \mathbf{B}, \mathbf{D}, \mathbf{E}, \mathbf{F}, \mathbf{G}$ & Chapter 13 of GP-4 book \\
\hline
\end{tabular}




\section{PROMISING GP APPLICATION AREAS}

- Problem areas involving many variables that are interrelated in highly non-linear ways

- Inter-relationship of variables is not well understood

- A good approximate solution is satisfactory

- design

- control

- classification and pattern recognition

- data mining

- system identification and forecasting

- Discovery of the size and shape of the solution is a major part of the problem

- Areas where humans find it difficult to write programs

- parallel computers

- cellular automata

- multi-agent strategies / distributed AI

- FPGAs

- "black art" problems

- synthesis of topology and sizing of analog circuits

- synthesis of topology and tuning of controllers

- quantum computing circuits

- synthesis of designs for antennas

- Areas where you simply have no idea how to program a solution, but where the objective (fitness measure) is clear

- Problem areas where large computerized databases are accumulating and computerized techniques are needed to analyze the data 


\section{TURING'S THREE APPROACHES TO MACHINE INTELLIGENCE}

- Turing made the connection between searches and the challenge of getting a computer to solve a problem without explicitly programming it in his 1948 essay "Intelligent Machines" (in Mechanical Intelligence: Collected Works of A. M. Turing, 1992, edited by D. C. Ince).

"Further research into intelligence of machinery will probably be very greatly concerned with 'searches' ... "1

\section{TURING'S THREE APPROACHES TO MACHINE INTELLIGENCE - CONTINUED}

\section{LOGIC-BASED SEARCH}

One approach that Turing identified is a search through the space of integers representing candidate computer programs.

\section{CULTURAL SEARCH}

Another approach is the "cultural search" which relies on knowledge and expertise acquired over a period of years from others (akin to present-day knowledge-based systems). 


\section{TURING'S THREE APPROACHES TO MACHINE INTELLIGENCE - CONTINUED}

\section{GENETICAL OR EVOLUTIONARY SEARCH}

"There is the genetical or evolutionary search by which a combination of genes is looked for, the criterion being the survival value."

- from Turing's 1950 paper "Computing Machinery and Intelligence" ...

"We cannot expect to find a good child-machine at the first attempt. One must experiment with teaching one such machine and see how well it learns. One can then try another and see if it is better or worse. There is an obvious connection between this process and evolution, by the identifications"

"Structure of the child machine $=$ Hereditary material"

"Changes of the child machine = Mutations"

"Natural selection = Judgment of the experimenter" 


\section{AUTHORED BOOKS ON GP}

Banzhaf, Wolfgang, Nordin, Peter, Keller, Robert E., and Francone, Frank D. 1998. Genetic Programming - An Introduction. San Francisco, CA: Morgan Kaufman Publishers and Heidelberg, Germany: dpunkt.verlag.

Babovic, Vladan. 1996b. Emergence, Evolution, Intelligence: Hydroinformatics. Rotterdam, The Netherlands: Balkema Publishers.

Blickle, Tobias. 1997. Theory of Evolutionary Algorithms and Application to System Synthesis. TIK-Schriftenreihe Nr. 17. Zurich, Switzerland: vdf Hochschul Verlag AG and der ETH Zurich. ISBN 3-7281-2433-8.

Jacob, Christian. 1997. Principia Evolvica: Simulierte Evolution mit Mathematica. Heidelberg, Germany: dpunkt.verlag. In German. English translation forthcoming in 2000 from Morgan Kaufman Publishers.

Jacob, Christian. 2001. Illustrating Evolutionary Computation with Mathematica. San Francisco: Morgan Kaufmann.

Iba, Hitoshi. 1996. Genetic Programming. Tokyo: Tokyo Denki University Press. In Japanese.

Koza, John R. 1992. Genetic Programming: On the Programming of Computers by Means of Natural Selection. Cambridge, MA: The MIT Press.

Koza, John R. 1994a. Genetic Programming II: Automatic Discovery of Reusable Programs. Cambridge, MA: The MIT Press

Koza, John R., Bennett III, Forrest H, Andre, David, and Keane, Martin A. 1999a. Genetic Programming III: Darwinian Invention and Problem Solving. San Francisco, CA: Morgan Kaufmann Publishers.

Koza, John R., Keane, Martin A., Streeter, Matthew J., Mydlowec, William, Yu, Jessen, and Lanza, Guido. 2003. Genetic Programming IV. Routine Human-Competitive Machine Intelligence. Kluwer Academic Publishers.

Langdon, William B. 1998. Genetic Programming and Data Structures: Genetic Programming + Data Structures = Automatic Programming! Amsterdam: Kluwer Academic Publishers.

Langdon, William B. and Poli, Riccardo. 2002. Foundations of Genetic Programming. Berlin: Springer-Verlag.

Nordin, Peter. 1997. Evolutionary Program Induction of Binary Machine Code and its Application. Munster, Germany: Krehl Verlag.

O'Neill, Michael and Ryan, Conor. 2003. Grammatical Evolution: Evolutionary Automatic Programming in an Arbitrary Language. Boston: Kluwer Academic Publishers.

Ryan, Conor. 1999. Automatic Re-engineering of Software Using Genetic Programming. Amsterdam: Kluwer Academic Publishers.

Wong, Man Leung and Leung, Kwong Sak. 2000. Data Mining Using Grammar Based Genetic Programming and Applications. Amsterdam: Kluwer Academic Publishers. 


\section{CONFERENCE PROCEEDINGS}

Banzhaf, Wolfgang, Daida, Jason, Eiben, A. E., Garzon, Max H., Honavar, Vasant, Jakiela,

Mark, and Smith, Robert E. (editors). 1999. GECCO-99: Proceedings of the Genetic and Evolutionary Computation Conference, July 13-17, 1999, Orlando, Florida USA.

San Francisco, CA: Morgan Kaufmann.

Banzhaf, Wolfgang, Poli, Riccardo, Schoenauer, Marc, and Fogarty, Terence C. 1998.

Genetic Programming: First European Workshop. EuroGP'98. Paris, France. Lecture

Notes in Computer Science. Volume 1391. Berlin, Germany: Springer-Verlag.

Koza Inhn R Foldherg David F, Fngel David R, and Rinlo, Rick I (editorc)

1996. Genetic Programming 1996: Proceedings of the First Annual

Conference. Cambridge, MA: The MIT Press.

Foster, James A., Lutton, Evelyne, Miller, Julian, Ryan, Conor, and Tettamanzi,

Andrea G. B. (editors). 2002. Genetic Programming: 5th European

Conference, EuroGP 2002, Kinsale, Ireland, April 2002 Proceedings. Berlin:

Springer.

Koza, John R., Deb, Kalyanmoy, Dorigo, Marco, Fogel, David B., Garzon, Max, Iba, Hitoshi, and Riolo, Rick L. (editors). 1997. Genetic Programming 1997: Proceedings of the Second Annual Conference. San Francisco, CA: Morgan Kaufmann.

Koza, John R., Banzhaf, Wolfgang, Chellapilla, Kumar, Deb, Kalyanmoy, Dorigo, Marco, Fogel, David B., Garzon, Max H., Goldberg, David E., Iba, Hitoshi, and Riolo, Rick. (editors). 1998. Genetic Programming 1998: Proceedings of the Third Annual Conference. San Francisco, CA: Morgan Kaufmann.

Miller, Julian, Tomassini, Marco, Lanzi, Pier Luca, Ryan, Conor, Tettamanzi, Andrea G. B., and Langdon, William B. (editors). 2001. Genetic Programming: $4^{\text {th }}$ European Conference, EuroGP 2001, Lake Como, Italy, April 2001 Proceedings. Berlin: Springer.

Poli, Riccardo, Nordin, Peter, Langdon, William B., and Fogarty, Terence C. 1999. Genetic Programming: Second European Workshop. EuroGP'99. Goteborg, Sweden, May 1999.

Lecture Notes in Computer Science. Volume 1598. Berlin, Germany: Springer-Verlag.

Poli, Riccardo, Banzhaf, Wolfgang, Langdon, William B., Miller, Julian, Nordin, Peter, and Fogarty, Terence C. 2000. Genetic Programming: European Conference, EuroGP 2000, Edinburgh, Scotland, UK, April 2000, Proceedings. Lecture Notes in Computer Science. Volume 1802. Berlin, Germany: Springer-Verlag. ISBN 3-540-67339-3.

Riolo, Rich and Worzel, William. 2003. Genetic Programming: Theory and Practice. Boston: Kluwer Academic Publishers.

Spector, Lee, Goodman, E., Wu, A., Langdon, William B., Voigt, H.-M., Gen, M., Sen, S., Dorigo, Marco, Pezeshk, S., Garzon, Max, and Burke, E. (editors). 2001. Proceedings of the Genetic and Evolutionary Computation Conference, GECCO-2001. San Francisco, CA: Morgan Kaufmann Publishers. Pages 57 - 65. Whitley, Darrell, Goldberg, David, Cantu-Paz, Erick, Spector, Lee, Parmee, Ian, and Beyer, HansGeorg (editors). GECCO-2000: Proceedings of the Genetic and Evolutionary Computation Conference, July 10 - 12, 2000, Las Vegas, Nevada. San Francisco: Morgan Kaufmann Publishers. 


\section{EDITED ADVANCES IN GENETIC PROGRAMMING BOOKS}

Angeline, Peter J. and Kinnear, Kenneth E. Jr. (editors). 1996. Advances in Genetic Programming 2. Cambridge, MA: The MIT Press.

Kinnear, Kenneth E. Jr. (editor). 1994. Advances in Genetic Programming. Cambridge, MA: The MIT Press.

Spector, Lee, Langdon, William B., O'Reilly, Una-May, and Angeline, Peter (editors). 1999. Advances in Genetic Programming 3. Cambridge, MA: The MIT Press.

\section{VIDEOTAPES ON GP}

Koza, John R., and Rice, James P. 1992. Genetic Programming: The Movie.

Cambridge, MA: The MIT Press.

Koza, John R. 1994b. Genetic Programming II Videotape: The Next Generation.

Cambridge, MA: The MIT Press.

Koza, John R., Bennett III, Forrest H, Andre, David, Keane, Martin A., and

Brave, Scott. 1999. Genetic Programming III Videotape: Human-

Competitive Machine Intelligence. San Francisco, CA: Morgan Kaufmann Publishers.

Koza, John R., Keane, Martin A., Streeter, Matthew J., Mydlowec, William, Yu, Jessen, Lanza, Guido, and Fletcher, David. 2003. Genetic Programming IV Video: Routine Human-Competitive Machine Intelligence. Kluwer Academic Publishers. 


\section{WILLIAM LANGDON'S BIBLIOGRAPHY ON GENETIC PROGRAMMING}

This bibliography is the most extensive in the field and contains over 3,034 papers (as of January 2003) by over 880 authors.

Visit

http://www.cs.bham.ac.uk/ wbl/biblio/

or

http://liinwww.ira.uka.de/bibliography/Ai/g enetic.programming.html

\section{GENETIC PROGRAMMING AND EVOLVABLE MACHINES JOURNAL FROM KLUWER ACADEMIC PUBLISHERS}

Editor: Wolfgang Banzhaf

\section{GENETIC PROGRAMMING BOOK SERIES FROM KLUWER ACADEMIC PUBLISHERS}

Editor: John Koza

kozalstanford.edu 


\section{GP MAILING LIST}

To subscribe to the Genetic Programming e-mail list,

- send e-mail message to:

genetic_programming-subscribelyahoogroups.com

- visit the web page

http://groups .yahoo.com/group/genetic_programming/

\section{INTERNATIONAL SOCIETY FOR GENETIC AND EVOLUTIONARY COMPUTATION (ISGEC)}

For information on ISGEC, the annual GECCO conference, or the bi-annual FOGA workshop, visit www.isgec.org

\section{FOR ADDITIONAL INFORMATION ON THE GP FIELD}

Visit

http://www.genetic-programming.org for

- links computer code in various programming languages (including $\mathbf{C}, \mathbf{C}++$, Java, Mathematica, LISP)

- partial list of people active in genetic programming

- list of known completed PhD theses on GP

- list of students known to be working on PhD theses on GP

- information for instructors of university courses on genetic algorithms and genetic programming 